Pamiętnik Literacki 2017, 4, s. 171-216
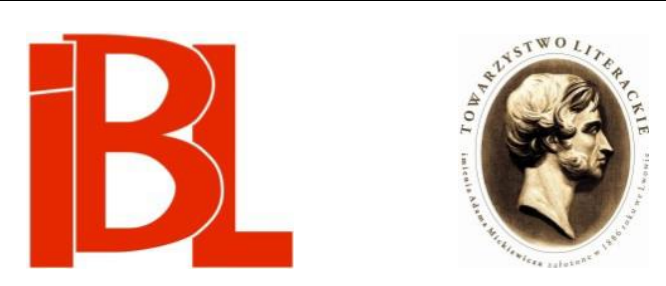

„Ciąży na mnie [...] obowiązek wierności”. Listy Teodora Parnickiego do Jana i Marty Erdmanów z lat 1944-1946

oprac. Andrzej Dobrowolski, Tomasz Markiewka 
Pamiętnik Literacki CVIII, 2017, z. 4, PL ISSN 0031-0514

DOI: $10.18318 / \mathrm{pl} .2017 .4 .10$

\title{
"CIĄŻY NA MNIE [...] OBOWIĄZEK WIERNOŚCI" LISTY TEODORA PARNICKIEGO DO JANA I MARTY ERDMANÓW Z LAT 1944-1946
}

\author{
Opracowali \\ ANDRZEJ DOBROWOLSKI Tarnów \\ TOMASZ MARKIEWKA Akademia Techniczno-Humanistyczna, Bielsko-Biała
}

Perypetie wojenne Teodora Parnickiego (1908-1988) i Jana Erdmana (1906-1986) dobrze ilustruja polskie losy w latach 1939-1945, są dla nich reprezentatywne, a wobec siebie do pewnego stopnia komplementarne.

Wrzesień 1939 Teodor Parnicki spędził w Borysławiu, u rodziny żony. W kampanii wrześniowej nie uczestniczył. Od władz wojskowych otrzymał zapewnienie, że jego kategoria zostanie powołana dopiero pod koniec grudnia. Do Lwowa wrócił 4 października i od razu przystapił, jako sekretarz (od 1936) oddziału lwowskiego Związku Zawodowego Literatów Polskich, do pracy u boku prezesa, Ostapa Ortwina. Przez pewien czas zarówno prezes, jak i sekretarz mieli pełne ręce roboty, spiesząc z pomocą licznym pisarzom przybywającym $z$ różnych stron Polski. Kiedy jednak we Lwowie zjawił się Aleksander Korniejczuk, delegat Zwiąku Pisarzy Sowieckich Ukrainy - z misją sowietyzacji form organizacyjnych środowiska pisarskiego w zajętym przez Armię Czerwoną mieście - obaj znaleźli się na marginesie oficjalnego życia kulturalnego. Aresztowanie nastapiło w nocy z 23 na 24 I 1940, o godz. 5.30 pisarz został osadzony w celi nr 80 więzienia na Zamarstynowie. Ze Lwowa przewieziono go do Horodni. Następnie trafił do więzienia NKWD w Czernihowie, gdzie sąd okręgowy skazał go na 8 lat pozbawienia wolności. Wyrok Parnicki odbywał w Czernihowie (w więzieniu miejskim), Nowogorodzie, Siewiersku i Kustanaju. W Kazachstanie doczekał się amnestii. Na wolność wyszedł 27 VIII 1941. W wieczór wigilijny 1941 r. dotarł do Kujbyszewa.

Jan Erdman walczył w obronie Warszawy. Po jej kapitulacji trafił do niemieckiej niewoli, a po wyjściu z niej dotarł przez Słowację na Węgry, skąd został ewakuowany do Syrii. Wstąpił do utworzonej w kwietniu 1940 Samodzielnej Brygady Strzelców Karpackich, która po kapitulacji Francji znalazła się w Palestynie, wchodząc w skład jednostek brytyjskich na Bliskim Wschodzie, a od sierpnia do grudnia 1941 uczestniczyła w obronie twierdzy Tobruk w Libii przed oddziałami niemieckimi Afrika Korps gen. Erwina Rommla. Ślad tego okresu w swoim życiu Erdman pozostawił w krótkim wspomnieniu o poległym współtowarzyszu broni, Pers z Brygady Karpackiej, które w 1947 r. ukazało się w jednej z pierwszych publikacji Instytutu Literackiego, jeszcze w Rzymie, zatytułowanej W oczach pisarzy. Wybór opowieści wojennych 1939-1945. Po wycofaniu się z linii frontu w marcu 1942 Brygada znów znalazła się w Palestynie, gdzie uległa rozformowaniu, a tworzące ją wcześniej oddziały od września do listopada były przenoszone do Iraku, w którym ostatecznie połączyły się z Armią Polską na Wschodzie. I w tych właśnie okolicznościach Erdman zakończył swoją karierę wojskowa. W grudniu 1942 został oddelegowany do Kujbyszewa.

Ambasador Stanisław Kot mianował Parnickiego zastępca attaché prasowego. Do jego głównych obowiązków należało redagowanie tygodnika (w rzeczywistości nieregularnika) 
„Polska”. Ich zakres znacznie się zwiększył, gdy w lipcu 1942 razem z ambasadorem opuścił Kujbyszew dotychczasowy attaché prasowy, Ksawery Pruszyński. A było to już po ewakuacji Armii Polskiej w ZSSR, a więc w okresie wyraźnego pogorszenia się stosunków polsko-sowieckich, o czym świadczyło choćby zamknięcie wszystkich polskich przedstawicielstw terenowych. W październiku 1942 do Kujbyszewa dotarł nowy ambasador, Tadeusz Romer. Zapowiedział przyjazd następcy Pruszyńskiego - miał nim być Jan Erdman. Po latach Parnicki nie krył, że wiadomość tę przyjął z mieszanymi uczuciami, bo nie wiedział, jak ułoży się współpraca między nimi: „on był zawodowym dziennikarzem, a ja byłem tylko li-

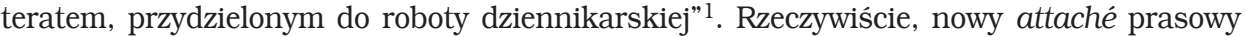
miał bardzo bogate doświadczenie w uprawianej przez siebie dziedzinie. Można powiedzieć, że $\mathrm{z}$ bliska śledził kolejne wydarzenia prowadzące do wybuchu drugiej wojny światowej: w 1933 r. relacjonował dojście Hitlera do władzy, w 1935 r. - plebiscyt w sprawie przynależności państwowej Zagłębia Saary, w 1936 r. - wojnę domową w Hiszpanii, w 1938 r. konferencję monachijską i rozbiór Czechosłowacji. W 1939 roku objechał całe Niemcy, obserwując przygotowania Hitlera do agresji na Polskę (wykrył m.in., że żołnierze Werhrmachtu zaopatrywani są w słowniczek niemiecko-polski). Dużą popularność Erdman zdobył jako dziennikarz sportowy: w 1932 r. był sprawozdawcą na olimpiadzie w Los Angeles, w r. 1936 zaś kierownikiem ekipy sprawozdawców na olimpiadzie w Berlinie. Ta przewaga Erdmana w znajomości profesji dziennikarskiej nie stała się jednak powodem jakichkolwiek zadrażnień. Obawy Parnickiego szybko się rozproszyły, o czym sam później zaświadczył:

W rzeczywistości okazało się zupełnie inaczej, niż przewidywałem - współpraca między nami ułożyła się bardzo dobrze; ktoś mógłby powiedzieć, że dlatego, iż jesteśmy tak zupełnie do siebie niepodobni, zaczynając od typu fizycznego, poprzez temperament, aż do sposobu reagowania na wydarzenia ${ }^{2}$.

Ewentualnym konfliktom zapobiegł też fakt, że ambasador Romer zdecydował się rozdzielić funkcje attaché prasowego i jego zastępcy do spraw kultury. Od tej chwili attaché prasowy i attaché kulturalny mieli taką samą rangę i byli niezależni od siebie.

Parnicki i Erdman spędzili ze sobą w Kujbyszewie pięć miesięcy: od grudnia 1942 do początków maja 1943, czyli do ewakuacji Ambasady RP do Iranu po jednostronnym zerwaniu przez władze sowieckie stosunków $\mathrm{z}$ rządem generała Władysława Sikorskiego. W nocy z 5 na 6 V 1943 jej pracownicy opuścili placówkę i specjalnym pociągiem udali się do leżącego niedaleko granicy irańskiej Aszchabadu, w którym wciąż jeszcze funkcjonowała polska delegatura. Granice przekroczyli w pięciu osobnych grupach. Nie wiadomo, w której grupie był Parnicki, natomiast Erdman znalazł się w ostatniej, kilkuosobowej.

I wówczas nie obyło się bez przykrości. Na granicy pracownicy zostali poddani drobiazgowej, poniżającej kontroli osobistej, podczas której musieli się nawet rozebrać do naga. Była to już [...] ostatnia szykana, jakiej władze radzieckie dopuściły się w stosunku do personelu polskiej misji dyplomatycznej ${ }^{3}$.

Przez następne miesiące 1943 r. zarówno Parnicki, jak i Erdman przemierzyli cały Bliski Wschód, od Iranu po Egipt. Mieli ze soba jakiś kontakt, bo jak wynika $z$ listów Parnickiego, imieniny Erdmana 24 VI 1943 obchodzili wspólnie w Damaszku. W tym czasie pisarz widział w Meszhedzie szyicki meczet $\mathrm{z}$ grobem Hasana ibn Alego, wnuka Mahometa, ośrodek wydobycia turkusów Niszapur, rzekę Tygrys pod Bagdadem, grób Saladyna w meczecie Umajjadów w Damaszku, miecz Gotfryda z Bouillon w kościele Grobu Świętego w Jerozolimie, Nil pod Kairem, piramidę Cheopsa w Gizie. Był to jednak dla niego przede wszystkim okres intensywnej pracy nad Srebrnymi orłami, które ukazały się w dwóch tomach w dzia-

1 T. Parni cki, Historia w literature przekuwana. Warszawa 1980, s. 16.

Ibidem.

3 B. Szubtarska, Ambasada polska $w$ ZSRR $w$ latach 1941-1943. Warszawa 2005, s. 174. 
łającym w Jerozolimie wydawnictwie przy dwutygodniku „W Drodze”, ale już po wyjeździe pisarza do Londynu (t. 1 w 1944, t. 2 w 1945 roku).

W roku 1944 zakończył się etap bliskowschodni w życiu Parnickiego i Erdmana. Autor Srebrnych orłów wyruszył z Suezu do Liverpoolu na okręcie „Orontes”, wiozącym wojska brytyjskie, natomiast jego przyszły korespondent wyjechał do Nowego Jorku, aby stanąc na czele redakcji czasopisma „Polish Facts and Figures”, wydawanego przez Polish Information Center (PIC), agendę rządu polskiego w Londynie. Spotkali się jeszcze w lipcu 1944, kiedy Parnicki w drodze do Meksyku, w którym miał objąć funkcję attaché kulturalnego w Poselstwie RP, zatrzymał się w Stanach Zjednoczonych. Poznał wówczas Martę Wańkowiczównę, z którą Erdman zamierzał wziąć ślub, co we wrześniu nastąiło. Marta Erdman (1921-1982) była młodszą córką Melchiora Wańkowicza, bohaterka jego reportażu Na tropach Smętka (1935) i powieści Ziele na kraterze (1951; wyd. krajowe: 1957). Pisarsko zadebiutowała w wieku 14 lat relacjami ze spływu kajakowego po rzekach i jeziorach Pojezierza Mazurskiego w Prusach Wschodnich, ukazującymi się na łamach „Płomyka”. Po maturze w r. 1938 wraz Z siostrą odbyła wyprawę rowerową po Francji (Lille, Paryż, Vichy, Grenoble, Marsylia, Cassis, Cannes, Monte Carlo, Les Sablettes). Sprawozdania z niej siostry publikowały w „Kurierze Porannym”. Po wakacjach Marta rozpoczęła naukę w Institut Français we Fryburgu w Szwajcarii (uzyskała dyplom nauczyciela języka francuskiego). Do Polski wróciła (przez Holandię i Szwecję) we wrześniu 1939, w pierwszych dniach wojny. Podczas kampanii wrześniowej pracowała w szpitalu w Chełmie. Następne miesiące spędziła w Warszawie. W marcu 1940 przez Wiedeń i Rzym wyjechała do Rumunii. 24 III 1940 dołączyła do ojca w Bukareszcie. Tutaj spisywała wspomnienia $z$ września 1939 i wygłaszała odczyty na ten temat po polsku i francusku. W maju 1940 wyjechała pociagiem do Genui, z której drogą morską udała się do Stanów Zjednoczonych. Na początku zamieszkała u rodziny przyjaciółki w Filadelfii. Podjęła naukę w Holy Child College w Rosemont, gdzie - w okresie dwuletniego pobytu - stworzyła siatkę uczennic wysyłających paczki do polskich żołnierzy osadzonych w obozach jenieckich, organizowała wieczory polskie, dawała odczyty po polsku i angielsku, publikowała w prasie polsko- i angielskojęzycznej. Napisała i wydała książkę $W$ szpitalu pod dwoma okupacjami (Chicago 1941). Po ukończeniu college’u otrzymała licencjat z języka angielskiego. W roku 1943 rozpoczęła studia prawnicze na University of Pennsylvania w Filadelfii, na którym w 1944 r. uzyskała magisterium na podstawie rozprawy o traktacie ryskim. Już podczas studiów podjęła pracę w Polish Information Center. I tu właśnie spotkała Jana Erdmana.

Korespondencja Teodora Parnickiego z Janem i Martą Erdmanami rozpoczęła się pod koniec 1944 r. od - najprawdopodobniej - dwóch osobnych listów świeżo poślubionych małżonków do pisarza. Zakończyła się w połowie 1946 r. listem Parnickiego, który od lutego nie mógł się doczekać odpowiedzi. Przypadła na okres szczególny w jego życiu, kiedy musiał podjąć istotne decyzje co do swojej przyszłości. 5 VII 1945 państwa współrozstrzygające wraz ze Związkiem Sowieckim o powojennej mapie Europy, Wielka Brytania i Stany Zjednoczone, uznając narzucony przez niego Tymczasowy Rząd Jedności Narodowej za realizacje postanowień konferencji jałtańskiej, cofnęły akceptację w stosunku do legalnego rządu Rzeczpospolitej Polskiej w Londynie, a tym samym podległe mu placówki skazały na likwidację. Poselstwo RP w Meksyku zakończyło swoją działalność 9 VII. Parnicki stanął przed dylematem: wracać do kraju czy pozostać na emigracji (w podobnej zresztą sytuacji znaleźli się Erdmanowie jako pracownicy nowojorskiego Polish Information Center).

Listy Parnickiego $\mathrm{z}$ tego czasu dają wgląd w motywacje, jakimi się kierował, odrzucając myśl o powrocie, mimo że wiele okoliczności $z$ jego punktu widzenia przemawiało na jej korzyść. Przede wszystkim powojenny ład w Europie zdawali się przyjmować do wiadomości (jeśli nie akceptować) ludzie, $z$ jednej strony, odgrywający do tej pory ważne role w polskiej polityce, a z drugiej - jakoś mu bliscy. Stanisław Kot, były ambasador RP w Moskwie-Kujbyszewie, były minister stanu na Bliskim Wschodzie i były minister informacji i dokumen- 
tacji w kolejnych rządach londyńskich, poparł decyzję Stanisława Mikołajczyka o wejściu do kontrolowanego przez komunistów Tymczasowego Rządu Jedności Narodowej. Sam został ambasadorem w Rzymie. Ksawery Pruszyński, attaché kulturalny w Ambasadzie RP w ZSSR, utalentowany pisarz, przyjał funkcje posła nadzwyczajnego w Holandii, a nieco wcześniej - w takich swoich ksiazżkach, jak Russian Year (New York 1944) i Margrabia Wielopolski (London 1944) - przygotował grunt dla uzasadnienia wolty politycznej dokonanej przez reprezentowany przez siebie odłam emigracji niepodległościowej. Kiedy Parnickiego doszły pogłoski, że Kot zostanie ambasadorem przy Watykanie, miał nawet „chwilę wahania” $i$ „parę bezsennych nocy", bo wydawało mu się, że dołączając do niego, stanąłby przed szansą urzeczywistnienia swojej „idée fixe na punkcie powrotu wschodniego chrześcijaństwa” i zaspokojenia „ambicji udziału w tworzeniu procesu dziejowego owego powrotu” (list 10). Był to jeszcze czas, kiedy - podobnie jak przed wojna - zakładał, że to właśnie humanizm katolicki jest główną siła zdolną do przeciwstawienia się ideologiom kolektywistycznym, wymierzonym w podmiotowość człowieka ${ }^{4}$. Swoje stanowisko w tej sprawie Parnicki z czasem zrewiduje (początek tego procesu wyznacza m.in. listy od ks. Waleriana Meysztowicza, o których pisarz wspomina w korespondencji z Erdmanami). W roku 1945 wciąż jednak uważał, że pozyskanie przez Kościół rzymskokatolicki wsparcia ze strony prawosławia uczyniłoby go bardzo groźnym przeciwnikiem dla komunizmu jako ideologii, która właśnie w r. 1945, dzięki stacjonowaniu Armii Czerwonej w Berlinie i Wiedniu, Rydze i Tallinie, Wilnie, Mińsku i Kijowie, Warszawie, Pradze i Budapeszcie, przeżywała największy chyba triumf w całych swoich dziejach. Parnicki zakładał, że los nieuchronnej konfrontacji między Zachodem a Związkiem Sowieckim rozstrzygnie się na płaszczyźnie ducha. Dlatego tak źle reagował na próby militaryzacji katolicyzmu, a więc upodobniania go do wroga, z którym miał się zmierzyć, przez propagowanie duchowości krucjat, o co oskarżał nieprzejednana część emigracji, uosabianej według niego przez generała Władysława Andersa.

Do powrotu do Polski mogły Parnickiego skłonić także powody osobiste. Co prawda, miasto jego młodości, Lwów, znalazło się w granicach ZSSR, ale żona Elżbieta, z którą został rozdzielony w jedna z nocy styczniowych r. 1940, po wojnie w wyniku tzw. repatriacji trafiła najpierw do Krakowa, później na Dolny Śląsk: początkowo do Świdnicy, a w końcu do Wrocławia. Pisarz nie widział większych szans na ściagnięcie jej za ocean, zdawał zaś sobie jednocześnie sprawę, że przedłużające się o kolejne lata oddalenie od siebie będzie skutkowało ostatecznym rozpadem ich związku. Dotkliwość sytuacji, w jakiej się znalazł, ujawniała się jeszcze wyraźniej na tle korespondencji z Erdmanami, szczególnie - zawartych w niej napomknień na temat ich życia małżeńskiego, budowania domu na obczyźnie, oczekiwań na narodziny pierwszego dziecka. To poczucie osamotnienia w przypadku Parnickiego niewątpliwie potęgowało żywione przez niego od dawna przekonanie, że rzeczywisty związek między mężczyzną a kobietą musi się opierać na głębokim porozumieniu duchowym i że on jako mężczyzna i pisarz potrzebuje kobiety, która odgrywałaby wobec niego rolę najbliższe-

4 Przy okazji omówienia powieści Bez oręża Z. Kossak-Szczuckiej pisał T. Pa rni cki (Literatura piękna katolickiego humanizmu. „Przegląd Powszechny” t. 218 〈1938〉, nr 4, s. 41-42): „Co właściwie będziemy nazywali humanizmem katolickim? Przede wszystkim idee głosząca, że pełnię rozwoju osiąga os obowość ludzka w katolicyzmie. Dalej sumę teoryj filozoficznych i estetycznych widzących w katolicyzmie najlepszą szkołę poznania is to ty człowieka jako przedmiotu badania i przedmiotu sztuki. Wreszcie szereg prądów i zjawisk literackich, które ortodoksyjnie katolicka postawę świata i człowieka łączą z pietyzmem dla wszelkich formalnych zdobyczy kultury humanistycznej dawnego typu (antymetafizycznej, antropocentrycznej) - także i tych, które formowały się poza obrębem kultury katolickiej, ba, nierzadko nawet w walce z nią... Do powyższych elementów dodajmy kierunki ideowe i artystyczne, dla których istota humanizmu mieści się w humanitaryzmie - to realizacja ewangelicznej nauki o miłości bliźniego, przejawiającej się w aktualnej praktyce w zwalczaniu wszelkiego barbarzyństwa i terroru”. 
go doradcy. Miał też świadomość, że zerwanej więzi nie zastąi mu bliskie środowisko intelektualno-duchowe, bo tego również był pozbawiony. To zresztą problem, $z$ jakim borykał się przez całe życie, tyle że wcześniej mógł liczyć na pełne zrozumienie ze strony przynajmniej garstki ludzi. Ich lista nie jest długa. Byli na niej: Konstanty Symonolewicz (przed wojna) oraz Stanisław Kot i Władysław Neuman (w czasie wojny). „No, ale trudno, trzeba przyzwyczaić się wreszcie być wiecznie samotnym i nie uważać cieni za rzecz uchwytną..." - pisał Parnicki melancholijnie (list 8).

Wreszcie ostatnia, ale też chyba najbardziej fundamentalna sprawa. W lipcu 1945 Parnicki stanął przed problemem zapewnienia sobie finansowych podstaw egzystencji. Musiał zastanowić się, w jakiej mierze jest w stanie w swojej twórczości wyjść naprzeciw oczekiwaniom czytelników przebywających na emigracji; w jakiej mierze jest władny zaspokoić ich potrzeby. Od nich wszak będzie zależało, czy uzyska środki potrzebne do życia. Jego doświadczenia pod tym względem nie były budujace. Dowodzi tego choćby relacja ze spotkania, jakie odbył $z$ prezesem najprężniejszej organizacji reprezentującej polskich emigrantów, czyli Kongresu Polonii Amerykańskiej:

Orientuję się [...], czym jest Polonia - mój typ umysłowy nie dla nich - moje ujęcie spraw kultury nie będzie się im podobało, a ja na kompromis nie pójdę.

[...] przywódcom jej nie przychodzi do głowy - przywódcom organizacji o blisko 40-tomilionowym majątku - zapytać mnie: - Panie, a może my byśmy mogli Panu pomóc w Pańskiej pracy jako powieściopisarza? [...] Ale takich pytań mnie nie stawiają: widocznie Parnicki-powieściopisarz Polonii nie interesuje. [list 13]

Z listów do Erdmanów wynika, że Parnicki przez dwa pierwsze lata pobytu w Meksyku sporo pisał, jakby gorączkowo poszukując takiego tematu i takiego sposobu jego ujęcia, który pozwoliłby mu zachować wierność sobie, a jednocześnie stać się pisarzem akceptowanym przez polską emigrację. W listach wspomina o pracy nad powieścią o Konstantynie I Wielkim i Minerwinie, o Mojżeszu i Helenie trojańskiej, nad drugą częścią Aecjusza, ostatniego Rzymianina, a przede wszystkim - nad powieścią współczesną Powrót Światowida i powieścią z dziejów Stanów Zjednoczonych. Ten ostatni projekt - przedsięwzięty za radą Ludwika Seidenmana z Nowego Jorku - należy już zresztą uznać za przejaw pewnej desperacji. Wyraźnie Parnicki podjął się go z myślą o zaistnieniu na amerykańskim rynku czytelniczym, przyjmując opinię Seidenmana, że tylko ono jest w stanie stworzyć mu warunki do kontynuacji własnej drogi pisarskiej. Akcja powieści miała toczyć się w Nowym Orleanie w latach wojny amerykańsko-brytyjskiej (1812-1815), z pewnymi nawiązaniami do poprzedzającej ją dekady, która rozpoczęła się od zakupu przez Stany Zjednoczonych całej Luizjany od Francji napoleońskiej (1803). Parnicki wykazywał się daleko idącą otwartością na sugestie Seidenmana, który oczekiwał od niego m.in., że zrezygnuje z charakterystycznej dla siebie wiwisekcji wewnętrznej bohaterów na rzecz atrakcyjnej fabuły i bogatego tła społeczno-obyczajowego. Chociaż współpraca ta od początku źle rokowała - Seidenman zastrzegł bowiem, iż Parnicki ma „pilnować książki przed samym sobą” ${ }^{5}$ - pisarz bardzo zapalił się do tego pomysłu, mimo że wcześniej historią Stanów Zjednoczonych się nie zajmował. W lutym 1946, mając już jedną trzecią powieści za sobą, planował, że ukończy ją w maju. Ostatecznie jednak przerwał pracę nad nią. Wpływ na to mogły mieć problemy z dostępem do źródeł i opracowań historycznych - lecz pamiętać należy, że na zapoznanie się z epoką poświęcił Parnicki aż 7 miesięcy intensywnych studiów ${ }^{6}$. Nie da się wszakże

$5 \quad$ L. Seiden ma n, list do T. Parnickiego, z 23 XI 1945 (maszynopis). Korespondencja przechowywana jest w Archiwum mecenasa Ludwika Seidenmana w Józef Piłsudski Institute of America w Nowym Jorku. Obejmuje ona listy z lat 1943-1945 (według oznaczenia katalogowego - w rzeczywistości w zbiorze są też listy z 1946 r.) i znajduje się w zespole nr 121 o sygn. 21.

6 W liście do Seidenmana z 28 VII 1946 T. Parni c ki zwraca się do swojego nowojorskiego „agen- 
wykluczyć, iż Parnicki uświadomił sobie, że Seidenman jako jego ewentualny agent literacki w Stanach Zjednoczonych wymagał od niego zbyt daleko idących kompromisów. Pisarz bowiem wyraźnie nie chciał ulec w sprawie zakończenia powieści. Seidenman upierał się przy happy endzie, natomiast Parnicki uważał, że czytelnik amerykański jest już wystarczająco dojrzały, aby zaakceptować powieść, która wymykałaby się konwencji popularnego romansu.

Wiele zatem okoliczności w latach 1944-1946 przemawiało za powrotem do Polski. Dlaczego więc Parnicki postanowił pozostać na emigracji? Najprostsza odpowiedź, jaka się nasuwa, jest taka, że wynikało to po prostu z konkretnego zamierzenia pisarskiego. Listy Parnickiego do Jana i Marty Erdmanów potwierdzają to, co już było wiadomo: że minister Kot nieprzypadkowo skierował go na placówkę do Meksyku ${ }^{7}$. Nieoficjalnym niejako powodem jego znalezienia się w tym właśnie miejscu był bowiem pomysł napisania powieści na tle historii konkwisty:

przyjechałem do Meksyku jako do krainy tyloletnich marzeń, aby zrealizować młodzieńczy jeszcze pomysł powieści o Cortésie i uroczej Azteczce, doñi Marinie... byłoby nonsensem, ba, upokorzeniem i klęską niezrealizowanie tego planu. Czas jakiś więc muszę tu jeszcze zostać... m u s z ę... [list 7]

Wola urzeczywistnienia owego projektu - a jednocześnie spłacenia długu wdzięczności wobec darzonego przez siebie wielkim szacunkiem profesora - wymagała zatem od Parnickiego odrzucenia wszelkich planów wiążących się z koniecznością wyjazdu, choćby do Stanów Zjednoczonych, nie mówiąc już o przemieszczeniu się na Stary Kontynent, w tym także do Polski. Listy do Erdmanów zdają się jednak rzucać światło na głębsze pokłady motywacji Parnickiego, który postanowił mimo wszystko nie wracać do kraju. Otóż od powojennej Polski, która znalazła się w strefie wpływów Związku Sowieckiego, odpychało go, paradoksalnie, szczere umiłowanie kultury rosyjskiej. Uformowany w niej, stał się jej znawca i miłośnikiem. Przed wojną dużą część swojej aktywności krytycznoliterackiej poświęcał literaturze rosyjskiej i sowieckiej. W jednym $z$ listów znajduje się znamienne wyznanie, że ,jeżeli chodzi o zagranicę”, najbliżej mu „psychicznie (choć nie myślowo)” do Rosji, tyle że do tej, która „się skończyła w r. 1917... a najściślej mówiąc, do tej, co trwała od lutego do października 1917... I może do Rosji Dostojewskiego z problemami religijno-metafizyczno-psychopatologicznymi..." (list 7). Niewatpliwie problematykę polsko-rosyjską w latach wojny i bezpośrednio po niej Parnicki przeżywał bardzo osobiście. Jego dwoistość pod tym względem utrwalił we wspomnieniu $\mathrm{z}$ pobytu w Kujbyszewie Józef Czapski:

Większość godzin dnia spędzałem u chorego wówczas pisarza Parnickiego, w jego pokoju w [...] Grand Hotelu. Znał on na pamięć ogromna ilość wierszy polskich i rosyjskich, Słowackiego przede wszystkim, ale i Błoka, Biełego, Tuwima, Lechonia, aż do Wittlinowskiego tłumaczenia Homera.

Pokój miał stare pożółkłe obicia, na środku pokoju wisiała jedna licha lampka elektryczna. [...] Parnicki leżał w wymiętej pościeli, żółty, nieogolony, i deklamował przede mną mieszankę polskich i rosyjskich, zawsze najpiękniejszych wierszy, godzinami. Jakaż była zgoda w tej republice poetów! Jak lotny, muzyczny język Biełego, Błoka wiązał się ze Słowackim, a Tuwim dotykał Puszkina i Błoka. Wy-

ta” z prośbą o wypłacenie 200 dolarów za drugie wydanie Aecjusza, ostatniego Rzymianina w „Royu”. Pisze: „O ile pozostałe argumenty zawiodą, możesz rzucić na stół karty w sprawie powieści "amerykańskiej«: z listów moich do Ciebie znasz zarys przewidziany treści i problemy - opowiedz im o tym, żem przez 7 miesięcy gruntownie studiował epokę... Postaw sprawę jasno: o ile mi nie dadzą teraz pieniędzy, zgodnie $z$ ich żądaniem dam im kolejne 3 książki, ale $z$ wyłączeniem amerykańskiej; o ile dadzą te 200 dolarów - mogę już teraz podpisać zobowiązanie, że u nikogo powieści "amerykańskiej" nie będę drukował, jak tylko w "Royu".

$7 \quad$ Zob. „Jak co roku, tak i tym razem $w$ dzien wigilijny...” Listy Teodora Parnickiego do Stanisława Kota z lat 1933-1962. Oprac. Z. Pi e tr zy k. „Pamiętnik Literacki” 1990, z. 4, s. $236,245$. 
chodziłem z tego pokoju późną nocą jak pijany, jak urzeczony poezją, powtarzając sobie te strofy skrzydlate tylko co usłyszane, strofy, które i tam umiały dotrzeć i uszczęśliwiać 8 .

Jeszcze w Ambasadzie RP w Kujbyszewie Parnicki snuł plany ułożenia powojennych stosunków między dwoma państwami. Ostatnim zadaniem, jakie w niej wykonał przed ewakuacją, było przygotowanie memorandum w tej sprawie, zatwierdzonego przez ambasadora Romera i przesłanego do Londynu. W latach 1941-1943 wypracowanie jakiegoś modus vivendi widocznie wydawało się Parnickiemu możliwe. W roku 1945 - po Teheranie i Jałcie - już nie miał złudzeń.

Proces dziejowy wykopał między mną a Heleną U[sijewicz] przepaść zaiste głębszą i szerszą niż Atlantyk. Ale szerszą niż Atlantyk okazuje się też być ulica Paseo de la Reforma - Natalia [Aszkenazy-Drohojowska] mieszka w hotelu po drugiej stronie ulicy, a dalej mi do niej, niż gdy była w Londynie... Oczywiście, jeśli zechce ze mną się spotkać na gruncie neutralnym - spotkam się z nią b[ardzo] chętnie. Ale jej się nie śpieszy. Czyżby czekała, że ja się zgłoszę? Nie mogę. Powinna to zrozumieć. M.in. i to, że właśnie jako przysięgły rusofil nie mogę aprobować w Polsce takiej sytuacji, która tylko pogłębia nienawiść między Polakami a Rosjanami. [list 11]

W komunistycznej Polsce pisarz nie widział więc dla siebie roli do odegrania. Człowiek z jego tożsamością mógł szukać spełnienia tylko poza krajem.

Świat powojenny Parnicki postrzegał jako arenę swoistej psychomachii, w której emigracja może odnieść zwycięstwo tylko pod warunkiem, że zdobędzie się na wysiłek w pracy intelektualnej, twórczej. W odpowiedzi na wieści, że jego bliżsi i dalsi znajomi szukają - nie mających nic wspólnego $z$ tak rozumianym celem wychodźstwa - sposobów ułożenia sobie życia, pisał:

a że z uporem maniaka trwam przy swym (nikomu niepotrzebnym, jak pewnie większość sądzi) powieściopisarstwie historycznym - to, widzisz, w tym, poza osobistym upodobaniem, jest pewna szersza idea: zdaje mi się, że Bieruta etc. wcale nie zmartwi, jeśli np. Erdman dobije się majątku w gospodarce rolno-hodowniczej - Seidenman w handlu - moi b[yli] koledzy z P[oselstwa] z Meksyku, Stebelski, major Dobrowolski - w aptekarstwie; nie, jego tylko ucieszy, że tych ludzi ubyło - choćby chwilowo w my ślowej robocie Polski dobrowolnie emigranckiej... Otóż ja - ostatkiem, co prawda, sił psychicznych - próbuję, by ni e ubyć... Czy mi się uda? nie wiem... [list 16]

To uparte trzymanie się statusu polskiego powieściopisarza historycznego brało się zresztą u Parnickiego nie tylko z pewnego rodzaju karności, nie dopuszczającej myśli o dezercji z pola walki. Wynikało ono $\mathrm{z}$ głębokiego przeświadczenia, że jedynie w ten sposób jest on w stanie zachować wierność wobec własnej tożsamości, co uważał za istotniejsze nawet niż samo życie:

Nie wiem, czy nie przesadnie oceniam wartość swej twórczości, ale poza twórczością nie widzę w sobie absolutnie żadnej już wartości, dla mnie samego nawet zasługującej na zabiegi, by za w s z e lk ą c en ę „przetrwać”... Życie ma sens o tyle tylko, o ile można żyć, tak jak się chce żyć... Jeżeli nie można być sobą, to po co być?! [list 7]

I chyba właśnie w wierności należy lokować odpowiedź na pytanie o motywy skłaniające Parnickiego do wybrania w 1945 r. losu pisarza emigracyjnego - wierności wobec własnej tożsamości, uformowanej w efekcie procesu polonizacji ${ }^{9}$, którego kulminacyjny moment

$8 \quad$ J. Cza p ski, Na nieludzkiej ziemi. Wyd. rozszerz. Paris 1984, s. 126.

9 O swojej polonizacji Parnicki opowiadał w wykładach na Uniwersytecie Warszawskim. Po wybuchu pierwszej wojny światowej, w r. 1915, ojciec pisarza, przebywający z rodziną w Rosji, aby nie trafić 
stanowiło rozpoznanie w sobie powołania do odnowienia polskiej powieści historycznej. Punktem wyjścia była kultura rosyjska, a punktem dojścia kultura polska. Parnicki pozostawał człowiekiem kulturowo rozdwojonym, ale tworzywem jego ekspresji artystycznej stał się ostatecznie język polski, podobnie jak był on tworzywem tych dzieł, które odegrały największą rolę w doprowadzaniu go do polskości: Króla-Ducha Juliusza Słowackiego oraz Ogniem i mieczem i Quo vadis Henryka Sienkiewicza. W gruncie rzeczy chodziło więc o wierność wielkim poprzednikom i całej stojącej za nimi tradycji kulturalnej, z którą Parnicki się identyfikował. Pamiętając, jak szybko postępowała sowietyzacja życia kulturalnego we Lwowie w pierwszych miesiącach po zajęciu go przez Armię Czerwoną ${ }^{10}$, pisarz nie mógł liczyć, że po 1945 r. będzie można jej zapobiec. Wierność tej tradycji kazała mu w emigracji widzieć jedyną szansę na jej ocalenie. Było jednak coś szczególnego, co zobowiązanie do zachowania wierności w nim potęgowało. Chodzi o kompleks żydowskiego pochodzenia:

ciąży na mnie, silniejszy może niż na kim innym, obowiązek w i e r n o ś c i, a to ze względu na ratowanie honoru krwi, co płynęła w żyłach mojej matki - bo na ogół ludzie tej krwi nie mają wiele zrozumienia dla elementu wierności. Niestety, to fakt, i nie można zaprzeczać jego istnieniu, choćby i znalazło się takie czy owo usprawiedliwienie... [list 11]

Można powiedzieć, że inaczej być nie mogło, trudno bowiem byłoby się spodziewać, iż w listach Parnickiego, w których tak ważne miejsce zajmuje kwestia tożsamości, nie da w końcu znać o sobie kompleks mieszańca, niezwykle istotny, niemal fundamentalny, dla całej twórczości pisarza.

Teodor Parnicki pozostał w Meksyku do 1967 roku. Za sprawą Końca „Zgody Narodów” (1955), Stowa i ciała (1960) oraz Nowej baśni (1962-1970) zrealizował swój plan odnowy polskiej powieści historycznej. Prace nad piątym tomem Nowej baśni, pt. Wylęgarnie dziwów (1968), zamkną 16 VI 1967 na statku PLO „Polanica” w drodze do Polski, tom szósty, Palec zagrożenia (1970), napisał w latach 1968-1969, już w Warszawie.

W życiu Jana i Marty Erdmanów też się sporo działo. W roku 1950 sprzedali oni farmę w pobliżu Lakewood, w stanie New Jersey, którą prowadzili od 1945 roku. W latach 1954-1958 Jan przebywał z rodziną (Martą i córkami) w Niemczech Zachodnich jako zastępca kierownika sekcji polskiej monachijskiej filii „Voice of America”. Po powrocie do Stanów Zjednoczonych, od 1962 do 1972 r., był redaktorem naczelnym polskiej edycji miesięcznika „Ameryka”. Marta w latach 1960-1968 współpracowała z działem wydawniczym National Planning Association w Waszyngtonie. Pod koniec lat sześćdziesiątych uczestniczyła w projekcie sponsorowanym przez Carnegie Corporation dotyczącym relacji między agendami rządowymi a biznesem. Pisała dla „Kultury”, „Wiadomości” i „Freehold Transcript” (New Jersey). Na początku lat siedemdziesiątych Erdmanowie zamieszkali w wyremontowanym przez siebie wiejskim domu w Middlefield w stanie Nowy Jork. W roku 1974 Marta Erdman przyjechała do Polski na pogrzeb Melchiora Wańkowicza. Na początku lat osiemdziesiątych Jan Erdman bywał w Polsce w związku z pracą nad książką o swoim szwagrze, podpułkowniku Macieju Kalenkiewiczu, pseudonim Kotwicz, cichociemnym, dowódcy Okręgu Nowogródek Armii Krajowej, która ukazała się pt. Droga do Ostrej Bramy (Londyn 1984). 1 I 1984 odwiedził Parnickiego. Pozostał po tym ślad w dzienniku pisarza:

jako poddany cesarza niemieckiego do obozu, wystarał się o dokumenty, że jest Polakiem. „I tak, prosze państwa, nabyłem świadomość, że jestem dzieckiem polskim. Jeszcze przez kilka lat ta "polonizacja " była na kredyt, dopiero różne przejścia w moim życiu, które doprowadziły mnie aż do kolonii polskiej w Charbinie, sprawiły, że znalazłem się na drodze do prawdziwej polonizacji" (P a r n i cki, Historia $w$ literaturę przekuwana, s. 316).

10 Zob. A. D o brow ols k i, „Inżynierowie dusz”. Uwagi Parnickiego do wspomnień Borwicza. „Zeszyty Historyczne" z. 144 (2003). 
Niespodziewana wizyta przybyłego ze Stanów Zjednoczonych J a na Er d m a n a [...]. Piłem wódkę (smorodinówkę [...]).

Piłem też czerwone wino, ale „odrzucało” mnie od niego ${ }^{11}$.

Za udostępnienie rękopisów listów Teodora Parnickiego oraz wszelką pomoc autorzy opracowania dziękują wnukowi Marty i Jana Erdmanów, Panu Dawidowi Walendowskiemu. Za udzielenie zgody na publikację listów, okazaną życzliwość, pomoc i wsparcie wyrażamy szczególną wdzięczność Pani Eleonorze Parnickiej (1922-2017). Ponadto dziękujemy wnuczce Zofii Kossak, Pani Annie Fenby Taylor, za gościnność i udostępnienie na spotkanie z panem Dawidem Walendowskim - w ostatniej fazie przygotowywania korespondencji - pracowni w Dworku Kossaków w Górkach Wielkich na Śląsku Cieszyńskim. Wszystkie cytaty z listów Teodora Parnickiego do Konstantego Symonolewicza pochodzą z pracy doktorskiej: Tomasz Markiewka, Lwowskie lata Teodora Parnickiego $w$ jego listach do Konstantego Symonolewicza (Uniwersytet Śląski 2002); ich rękopisy znajdowały się od lat siedemdziesiątych w. XX w zbiorach prywatnych Zygmunta Lichniaka (1925-2015), w 2016 r. zostały przekazane do działu zbiorów specjalnych Biblioteki Jagiellońskiej. Kwerenda dr. Tomasza Markiewki w Józef Piłsudski Institute of America w Nowym Jorku, dotycząca wykorzystanych w niniejszym opracowaniu listów Teodora Parnickiego do Ludwika Seidenmana, możliwa była dzięki stypendium The Kosciuszko Foundation oraz finansowemu wsparciu The Cleveland State University (USA).

W publikowanych tu listach modernizujemy pisownię oraz interpunkcję, zachowując jednakże pewne cechy charakterystyczne, jak końcówki dodawane do liczebników (2-gi, 50-ciolecie) czy duże litery stosowane (niekonsekwentnie) przez Parnickiego ze względów grzecznościowych oraz w tytułach dzieł literackich, jak też używane w nadmiarze myślniki. Podkreślenia oddajemy drukiem rozstrzelonym. Autor używał wyłącznie nawiasów okragłych - w wypadku wystąpienia nawiasów drugiego stopnia posługujemy się nawiasami kątowymi \langle\rangle . W nawiasach kwadratowych [ ] umieszczamy rozwinięcia skrótów (łącznie ze skrótami w zapisach dat), a także nazwiska osób wymienionych tylko z imienia. Częste u Parnickiego dopiski na marginesach ujęte zostały w klamry \{\}. Ujednolicono układ nagłówków i podpisów.

26/XII [19]44

Mój Kochany!

Listy Twój i P. Marty przyszły w jak najwłaściwszej chwili: w chwili takiej depresji psychicznej, jakiej nie przeżywałem chyba jeszcze nigdy, a znasz mnie, na jakie mnie (choćby w Kujbyszewie ${ }^{1}$ ) było stać... Kister ${ }^{2}$ pisał do mnie bardzo zwięźle: „książka mi się bardzo podoba. Ale przed przeczytaniem drugiego tomu nie moge powziąć żadnej decyzji”3. A więc Wasze 2 listy to istotnie „Gwiazdka” nie byle jaka!

Dziękuję Ci za troskę o moje kłopoty, m.in. pieniężne. Ale nie ma się czym przejmować: kiedyś Marian Strumiłło ${ }^{4}$ powiedział, że gdybym miał 400 funtów miesięcznie, to bym tak samo wszystko wydawał szybko, zaciągał długi i tkwił w wiecznych kłopotach... Z tego nigdy prawdopodobnie nie wyjdę, chyba że będę miał przy sobie kogoś, kogo bym chciał i musiał utrzymywać, a kto ze swej

11 T. Parn i cki, Dzienniki z lat osiemdziesiątych. Notatki o własnej pracy literackiej. Wstęp Z. Li c hniak. Słowo o autorze dzienników oraz oprac. T. Marki ewka. Kraków 2008, s. 391. 
strony pilnowałby mnie, abym nie robił głupstw... Ale nikogo takiego nie mam jestem bardzo samotny... ${ }^{5}$

Cieszę się, gdy moja twórczość znajduje uznanie u ludzi, których opinia jest naprawdę cenna i istotna - ale gdybyż ci ludzie zdawali sobie sprawę, ile mnie kosztuje ten wysiłek twórczy... ile płacić trzeba z „pełni człowieczeństwa” za możność zdobycia się na taki wysiłek... Nie masz pojęcia, jak się dziwaczeje i wykoszlawia, gdy się jest opętanym przez świat wizyj i problemów... I jak to męczy!

A najwięcej męczy ciagły niepokój, że nie będzie się miało czasu i możności zrealizować do końca własne wizje twórcze: lada bowiem chwila porazić może cios Boga Trwogi na Czarnych Szlakach ${ }^{6} .$. boga, ironicznie uśmiechniętego... Jakże zazdroszcze Tobie, gdy piszesz: „gdzieś koło września spodziewamy się przenieść do większego mieszkania”. Wrzesień!... A ja nie wiem, czy jeszcze jutro będę mógł kontynuować kolejny rozdział Buntu Marii Młodszej - bo przecież cios (taki czy owaki) nadejść może lada sekunda...

Z Londynu nikt do mnie nie pisze: niepokoję się o nich tam, głównie o Ludwika $[\text { Seidenmana }]^{8}$, Rojka ${ }^{9}$, p. Kossowską ${ }^{10}$, Profesora [Kota ${ }^{11} \ldots$

Dorocznym zwyczajem włożyłem na Wilje „kocią” koszulę: tę, którą dał mi Profesor ze swych własnych, gdym - w sam dzień Wilii 1941 - przybył do Ambasady z Kustanaju ${ }^{12}$ \{mając na sobie pod ubraniem, zamiast koszuli, piżamę... $\}^{13} \ldots$ Zniszczona już jest bardzo, tak że wkładam ją tylko raz w roku na jeden wieczór...

\{Załączam tu list do Pani Marty. Ciekawe, że żadne $z$ Was nie dało podpisu na swym ostatnim liście. Czy pani Marysia ${ }^{14}$ wciąż żywi do mnie wrogie uczucia? Którejś nocy śniła mi się wielokrotnie (budziłem się coś ze 3 lub 4 razy, a gdym zasypiał znowu, zawsze śniła mi się). $\}^{15}$

\{Czy mógłbyś mi wyjaśnić, dlaczego Krysia - wyraźnie demonstracyjnie - przestała „mnie znać”? $\}^{16}$

\{Ściskam Ciebie, Janku, bardzo serdecznie - już chciałem napisać, że dobrze by było, gdybyśmy mogli znowu się z sobą zobaczyć, ale złapałem się za język: dziwaczeję bowiem coraz bardziej, muszę być nawet dla przyjaciół coraz bardziej męczący - więc może lepiej, by głos mój do tych, którzy są mi bardzo bliscy, dochodził $z$ daleka.... ${ }^{17}$

\section{Teodor}

Pojedyncza karta papieru średniej grubości o wymiarach $21 \times 27,5 \mathrm{~cm}$, zapisana obustronnie ciemnogranatowym atramentem. Pismo duże i czytelne, średnie odległości między linijkami tekstu. Szeroki lewy margines. Dopiski na lewym marginesie karty recto i verso w układzie pionowym. U dołu karty recto dopisek oddzielony linią oraz uzupełnienie oznaczone strzałką.

1 Jan Erdman i Teodor Parnicki pracowali razem w Ambasadzie RP w Kujbyszewie od 10 XII 1942 do maja 1943.

2 Marian Ki s ter (1897-1958) - wydawca, w latach 1924-1939 współwłaściciel (razem z Melchiorem Wańkowiczem) i dyrektor Towarzystwa Wydawniczego „Rój”. Parnicki opublikował w „Roju” broszurę historyczno-biograficzną Czan-Tso-Lin (1931) i powieść Aecjusz, ostatni Rzymianin (1937). W czasie wojny działalność wydawnictwa została wznowiona w Nowym Jorku - najpierw jako „Roy in Exile”, a następnie „Roy Publishers”. Jako pierwsze książki w okresie nowojorskim zostały wydane tomy poetyckie: K. Wi e r zy ń s ki e go Róża wiatrów (1942) i J. Tu wi ma Wybór wierszy (1942). Dużym sukcesem firmy było opublikowanie w $1943 \mathrm{r}$. tłumaczenia powieści Z. K o s s a k- S z c z u c k i e j Bez oręża. W roku 1945 „Roy Publisher” wznowił Aecjusza, ostatniego Rzymianina. Po wojnie stopniowo w ofercie wydawniczej zaczęły dominować tłumaczenia literatury polskiej na 
język angielski, m.in. dzieła B. Malinowskiego, O. Haleckiego, S. Vincenza. Po śmierci Kistera wydawnictwem zaczęła kierować jego żona, Anna (1902-1997). W latach sześćdziesiątych wydawnictwo ufundowało Nagrodę im. Mariana Kistera.

3 W roku 1944 w Jerozolimie (w serii „Biblioteka "W Drodze»") ukazał się pierwszy tom Srebrnych orłów Teodora Parnickiego (w 1945 wyszedł tom drugi). Pisarz zabiegał o jego wznowienie u Mariana Kistera.

4 Marian Strumiłło (1865-1951) - adwokat, w latach 1920-1924 dziekan Rady Adwokackiej w Wilnie oraz członek Naczelnej Rady Adwokackiej, członek Trybunału Stanu; w 1935 r. senator RP z ramienia BBWR; w latach 1941-1943 radca ds. finansowych Ambasady RP w Moskwie-Kujbyszewie; po 1945 r. mieszkał w Rabce.

5 Parnicki kontakt z żoną stracił po aresztowaniu go przez NKWD we Lwowie w nocy z 23 na 24 I 1940. Elżbieta Parnicka (1909-1983), z domu J a ck ow s ka - pierwsza żona Teodora Parnickiego (od 23 IV 1934 do formalnego rozwodu w sierpniu 1954); ukończyła studia chemiczne na Uniwersytecie Jana Kazimierza; po wojnie mieszkała w Krakowie, Świdnicy i we Wrocławiu, gdzie pracowała w RSW „Prasa-Książka-Ruch”. Wydane w latach 1944-1945 w Jerozolimie Srebrne orły ukazały się z dedykacją „Elżbiecie Parnickiej, gdziekolwiek jest”.

6 Parnicki nawiązuje tutaj do przekładu wiersza Wozwraszczenije Odissieja (Powrót Odysa) N. G umilow a z tomu Żemczuga (Perty) z r. 1910, dokonanego przez K. Sy monolewicza juniora: „Hejże się zbieraj, mój Telemaku, / W długą wędrówkę wężami dróg: - / Musimy służyć na czarnym szlaku / Bezlitosnemu bożyszczu trwóg... // Znów ukochamy mamiącą dal my, / Księżyc nam złotem szlak będzie słał; / I znowu święte ujrzymy palmy, / Wielkiego Pontu spieniony wał... // Choć nie splamione królowej łoże, - / Grzesznych już marzeń poznała moc: - / Czajki są bielsze, jaśniejsze - zorze / Niźli jej piękność, ciemna jak noc" (cyt. za: T. Parnicki, M. S. Gumilow i „akmeiści” rosyjscy. 〈Wjedenastą rocznicę śmierci poety〉. „Myśl Narodowa” 1932, nr 38, s. 547-548).

7 Najprawdopodobniej chodzi o - bliżej nie zidentyfikowane - dzieło historyczne o Marii I Tudor (1516-1588), córce Henryka VIII, określonej przez pisarza „Młodszą” dla odróżnienia od Marii Tudor (1496-1533), siostry króla. W latach 1553-1558 jako królowa Anglii podjęła nieudaną próbę rekatolizacji kraju. Doprowadziła m.in. do aresztowania, skazania i spalenia na stosie arcybiskupa Canterbury Thomasa Cranmera. W latach sześćdziesiątych pisarz myślał o wykorzystaniu innego wydarzenia z dziejów zmagań o powrót katolicyzmu w Anglii: o tzw. spisku prochowym, czyli zamachu w 1605 r. na króla Jakuba I.

8 Ludwik Seidenman (1906-2003) - prawnik, od 1933 r. do początku drugiej wojny światowej prowadził kancelarię adwokacką w Warszawie; w 1939 r. znalazł się w Wilnie; po wybuchu wojny sowiecko-niemieckiej w czerwcu 1941 został aresztowany przez NKWD; po zwolnieniu na mocy amnestii ogłoszonej po podpisaniu umowy Sikorski-Majski był radcą prawnym w Ambasadzie RP w Moskwie-Kujbyszewie, w której zajmował się sprawami żydowskimi; w lipcu i sierpniu 1943 był wicekonsulem RP w Jerozolimie; w latach 1943-1945 reprezentował Ministerstwo Informacji i Dokumentacji w Ambasadzie RP w Waszyngtonie; następnie był zatrudniony w Polskim Centrum Informacji w Nowym Jorku i Londynie; po drugiej wojnie światowej pozostał w Nowym Jorku, gdzie pracował jako adwokat.

9 Marian Emil Ro j e k (Ro y e k) (1905-1968) - dziennikarz i publicysta; działacz narodowy: w latach 1941-1946 redaktor londyńskiej „Myśli Polskiej”, w latach 1941-1951 członek Komitetu Politycznego Stronnictwa Narodowego; w 1951 r. przeniósł się do USA; od 1958 r. członek Polskiego Instytutu Naukowego w Nowym Jorku; znajomy Parnickiego z czasów lwowskich.

10 Stefania Kos s ow sk a (1909-2003), z domu Szurlej - krytyk literacki, prozaik, felietonistka; studiowała prawo na Uniwersytecie Warszawskim, jednocześnie publikowała na łamach tygodnika „Prosto z Mostu”; podczas wojny była zatrudniona w Ministerstwie Informacji i Dokumentacji; drukowała artykuły w „Wiadomościach Polskich”; w 1953 r. ściśle współpracowała z „Wiadomościami”, prowadząc, jako Big Ben, rubrykę „W Londynie”; od 1969 r. w związku z chorobą Mieczysława Grydzewskiego współredagowała pismo wraz z Michałem Chmielowcem; od 1973 r. kierowała nim samodzielnie, aż do ich zamknięcia w 1981 roku. Autorka tomu esejów Mieszkam $w$ Londynie (Londyn 1964) oraz artykułów i felietonów Jak cię widzę, tak cię piszę (Londyn 1973).

11 Stanisław Kot (1885-1975) - historyk kultury, polityk, autor wspomnień; od 1920 r. profesor Uniwersytetu Jagiellońskiego, od 1921 r. członek Polskiej Akademii Umiejętności, znawca dziejów ideologii i doktryn społeczno-kulturalnych XVI i XVII w.; w latach 1941-1942 ambasador RP 
w ZSSR, w latach 1942-1943 - minister stanu na Bliskim Wschodzie, w 1944 r. minister informacji i dokumentacji; w 1945 r. wraz ze Stanisławem Mikołajczykiem wrócił do Polski, skąd został wysłany jako ambasador do Rzymu; od 1947 r. na emigracji. Autor m.in. Listów z Rosji do generała Sikorskiego (1956) i Rozmów z Kremlem (1959). W roku 1933 Parnicki nawiązał korespondencyjny kontakt ze Stanisławem Kotem jako redaktorem „Biblioteki Narodowej” (1919-1947), proponując przygotowanie dla niej Wyboru poezji rosyjskiej końca XIX i poczatku XX wieku. Zob. „Jak co roku, tak i tym razem $w$ dzień wigilijny...” Listy Teodora Parnickiego do Stanisława Kota z lat 1933-1962. Oprac. Z. Pi etr zy k. „Pamiętnik Literacki” 1990, z. 4.

12 Kustanaj - miasto w północnym Kazachstanie, nad rzeką Toboł. Parnicki od stycznia 1940 przebywał w sowieckich więzieniach. W Kustanaju spędził ostatni etap swojego uwięzienia. Wolność odzyskał 27 VIII 1941 jako obywatel polski na mocy amnestii ogłoszonej po podpisaniu umowy Sikorski-Majski.

13 Dopisek w lewym dolnym rogu k. 1r, oznaczony strzałką.

14 Marysia / Marysia S., Krysia, Irena / Irena Prażmowska - te wielokrotnie wymieniane w listach Parnickiego osoby najprawdopodobniej należały do kręgu towarzyskiego Marty i Jana Erdmanów, dzięki czemu pisarz mógł je poznać podczas swojego pobytu w lipcu 1944 w Nowym Jorku, znajdując się w drodze do Meksyku. Żadnych informacji na ich temat nie udało się jednak zebrać.

15 Dopisek wzdłuż lewego marginesu k. lv.

16 Dopisek u dołu stronicy, oddzielony poziomą kreską od tekstu głównego.

17 Dopisek wzdłuż lewego marginesu k. lr.

Drogi Janku!

Wiesz już zapewne o nominacji P. Min[istra] Neumana ${ }^{1}$ na stanowisko ${ }^{2}$ Szefa całej propagandy polskiej w obu Amerykach. Wyjeżdża do N[ew] Yorku: sądzę, że byłoby bardzo wskazane, byś nawiązał z nim kontakt. Mówiłem z nim bardzo dużo o Tobie: z największym przekonaniem mówiłem mu o Tobie jako o kimś, na kogo w pracy swej powinien zwrócić szczególną uwagę. Tyle ja: co do reszty, sam będziesz wiedział, jak masz postępować.

Czy byłbyś tak łaskaw wytłumaczyć mi tajemnicę milczenia Krysi? tylekroć do niej pisałem, a wszystko bez odpowiedzi. Choćby miały to być rzeczy przykre dla mnie, napisz, jak to wygląda naprawdę.

Również i p. Irena, która raczyła odnosić się do mnie w N[ew] Yorku z przyjaźnią, nie odpisała na żaden $\mathrm{z}$ moich 3 listów. Ale może ona wyszła za mąż i - rzecz naturalna - pochłonięta jest całkowicie Nowym Życiem?

Pani Marcie ręce całuję, Ciebie ściskam serdecznie.

Teodor

Pojedyncza karta o wymiarach 21,5 × 27,9 cm, zapisana obustronnie ciemnoniebieskim atramentem. Papier średniej grubości, lekko pożółkły. Szeroki lewy margines na obu stronicach. Karta recto zapełniona do połowy, podpis nadawcy pismem nieco bardziej rozstrzelonym.

$1 \quad$ Władysław N e u man (1893-1945) - dyplomata, w latach 1927-1931 był radcą Ambasady RP w Paryżu, od 1931 r. ministrem pełnomocnym i posłem nadzwyczajnym polskiej placówki dyplomatycznej w Oslo; po ataku niemieckim na Norwegię i jej klęsce w czerwcu 1940 towarzyszył królowi Haakonowi VII w podróży do Londynu, gdzie później pełnił swoją funkcję przy rządzie norweskim na emigracji. Krytyczny wobec układu Sikorski-Majski, został z niej w czerwcu 1942 odwołany. Od marca 1943 do 1945 r. poseł RP w Meksyku. Był miłośnikiem i znawcą literatury, szczególnie okresu romantyzmu, w czym przypominał mentora Parnickiego z okresu harbińsko- 
-lwowskiego, Konstantego Symonolewicza, oraz samego Parnickiego. Zob. W. Lange, Poset nadzwyczajny. Rzecz o Wtadysławie Neumanie. „Rocznik Łódzki” t. 52 (2005).

2

W rękopisie: „stanowiska”.

México, 8/III [19]45

\section{Droga Pani Marto!}

Strasznie dawno już nie miałem wiadomości ani od Pani, ani od Janka. Rozumiem, że nie bardzo ma się teraz humor na czysto intelektualną wymianę myśli; ale przecież może coś Państwo do mnie napiszecie. Janek powinien był mieć ode mnie list w dniu przyjazdu ministra Neumana do Nowego Yorku. Śmierć p. Neumana ${ }^{1}$ była dla mnie osobiście szczególnie bolesnym ciosem; sam jeden zastępował mi całe polskie środowisko intelektualne i literackie... Specjalnie silnie odczułem brak jego na swym pierwszym hiszpańskim wykładzie (na tutejszym Uniwersytecie ${ }^{2}$ ): Neuman bowiem był głównym inspiratorem tego wykładu i wśród słuchaczy on powinien by był zajmować pierwsze miejsce...

Za miesiąc mam wystapić $z$ drugim odczytem: obchód 50-lecia Quo Vadis pod patronatem PEN Clubu meksykańskiego.

Mam do Pani, Droga Pani Marto, parę próśb:

[1)] Czy dział radiowy PIC- $\mathrm{u}^{3}$ potrzebowałby 15-20-minutowych słuchowisk na tematy \{współczesnej\} ${ }^{4}$ walki Polski $z$ Niemcami? Obsługuję tu słuchowiskami nasze audycje radiowe ${ }^{5}$; może by one przydały się i w Stanach; zawierają wprawdzie pewne nawiązania do Meksyku, ale to by na miejscu mógł jakiś „spec” od radia łatwo zmienić...

2) Czy Kister nie zmienił adresu? Od dawna mi już nie odpowiada, i to na szereg listów, a na odpowiedzi jego za le ży mi bardzo. Niech go Pani łaskawie przy najbliższej okazji zagadnie o to milczenie...

Zapytać może Pani, dlaczego to Ją właściwie „uszczęśliwiam” tymi prośbami, a nie np. Janka... Po pierwsze dlatego, bo mam doświadczenie, iż kobiety na ogół chętniej i dokładniej wykonywają powierzone im tego rodzaju zlecenia... Po drugie, iż do Pani mam jeszcze sprawę nadto: Kister musiał dostać ode mnie miniaturowe fotograficzne wydanie Aecjusza ${ }^{6}$; cieszyłbym się, gdyby Pani i tę też książkę moją przeczytała. Zależy mi na zdaniu Pani: chodzi przede wszystkim o to, że bardzo wiele osób twierdzi, że Aecjusz jest lepszy od Srebrnych Orłów ${ }^{7}$ - gdyby tak było naprawdę, to by mnie niepokoiło: dowodziłoby regresu talentu. Chciałbym więc znać Pani sąd porównawczy o obu tych książkach.

Liczę się z tym, że Kister lada dzień powinien otrzymać 2-gi tom Srebrn[ych] Orłów: miano mu posłać z Jerozolimy bezpośrednio. Myślę, że i ten tom, jak pierwszy, od razu da Pani do przeczytania. Niech mi Pani wtedy napisze - ale to bardzo szczegółowo - swoje uwagi o zakończeniu książi. Pierwotnie miało być inne: miały być jeszcze 3 rozdziały, $z$ nich \{jeden, poświęcony motywowi wykorzystania Arona 8 przez Bolesława, jako czynnika „propagandowego” w wojnie polsko-niemieckiej, którą to wojnę książkowe zakończenie tylko zapowiada. ${ }^{9}$

\{- Piszę teraz powieść ni e historyczną i męczę się: przejście - zarówno psychologiczne, jak stylistyczne - niezmiernie jest trudne. 
- Pisał mi Ludwik S[eidenman] z Londynu, że wraca do N[ew] Yorku. Czy może już jest?

- Niepokoi mnie to, że może Pani - ze względu na swój wzrok - będzie się bała zbyt drobnego druku Aecjusza.

- Sądzę, że Janek nie pogniewa się na mnie o to, że na kopercie umieściłem oba nazwiska Pani: ale skoro Pani $z$ tamtym weszła do literatury ${ }^{10}$, więc je też umieszczam...

Ręce Pani całuję.

Janka ściskam serdecznie, proszę o list.

\section{Teodor Parnicki ${ }^{11}$}

Pożółkła karta papieru średniej grubości, o wymiarach $21 \times 27,5 \mathrm{~cm}$, zapisana obustronnie ciemnogranatowym atramentem. Pismo równe, szeroki margines lewy, na nim w układzie pionowym dopiski (karta recto: 8 linijek, karta verso: 4 linijki).

$1 \quad$ Władysław Neuman przyjechał z Meksyku do Nowego Jorku w sprawach urzędowych (miał objąć kierownictwo akcji informacyjno-propagandowej rządu RP na całej półkuli zachodniej). Umarł na ulicy 24 I 1945 bezpośrednio po swojej rozmowie z Emanuelem Freydem, byłym urzędnikiem Ambasady RP w Moskwie-Kujbyszewie. Zob. J. D ro h oj ow ski, Wspomnienia dyplomatyczne. Kraków 1969, s. 241.

2 Narodowy Uniwersytet Autonomiczny Meksyku (Universidad Nacional Autonóma de México) - najstarszy uniwersytet w Ameryce Północnej, założony w 1551 roku.

3 Polish Information Center - agenda Ministerstwa Informacji i Dokumentacji rządu londyńskiego, powołana w 1940 r. w Nowym Jorku; do jej zadań należało informowanie opinii publicznej i organów rządowych w Stanach Zjednoczonych o sytuacji w okupowanej Polsce, działalności Rządu RP, walce zbrojnego podziemia w kraju i Polskich Sił Zbrojnych na Zachodzie; wspierała też wychodźcze środowisko naukowo-artystyczne; działała do 5 VII 1945. Centrum nie miało działu radiowego.

4 Uzupełnienie nad linią tekstu głównego.

5 Trudno powiedzieć, o jakich „naszych audycjach radiowych” Parnicki pisał. Od początku września 1939 działała polska sekcja BBC; w czasie wojny istniała też sekcja polska przy Radiu Watykańskim. Polskojęzyczne radiostacje nadawały z Teheranu, Bejrutu, Jerozolimy i Kairu. W roku 1943 zainaugurowało swoją działalność radio „Espectador” w Montevideo, utrzymywane wyłącznie ze składek Polaków z Urugwaju, Argentyny i Brazylii. Od lipca 1945 audycję Polski Biuletyn Informacyjny prowadził w nim Czesław Straszewicz.

$6 \quad$ Kopia wydania 1, z 1937 roku.

7 Pierwszy tom Srebrnych orłów ukazał się w r. 1944 - zob. list 1, przypis 3.

8 Aron (zm. 1059?) - biskup krakowski w latach 1048-1059, zapewne arcybiskup dla całej Polski. Teza o jego pochodzeniu iroszkockim, przyjmowana jeszcze w początkach XX w. (np. W. Szcześn i a k, Aron. Hasło w: Podręczna encyklopedia kościelna. T. 1. Warszawa 1904, s. 2), współcześnie jest przez historyków odrzucana (zob. „Ale mój świat to zaklęte koło...” Listy Teodora Parnickiego do Tymona Terleckiego z lat 1942-1943. Oprac. T. M a r k i e w k a. „Pamiętnik Literacki” 2000, z. 1, s. 202 〈list 3, przypis 6〉). Aron stał się też jednym z głównych bohaterów Robotników wezwanych ojedenastej (1962), części pierwszej cyklu Nowa baśń (1962-1970). Parnicki dokonał w niej zabiegu, którego celem było pogodzenie ze sobą dawnych i nowych ustaleń historyków na temat tej postaci: rozbił żywot Arona na dwie części. W Robotnikach... uczynił go bowiem ofiarą katastrofy morskiej, z której wyszedł on, co prawda, z życiem, lecz stracił pamięć, a więc i swoją wcześniejszą tożsamość. Jako że po wyłowieniu z morza znalazł się w klasztorze w Brauweiler w okolicach Kolonii, można powiedzieć, iż mnich Aron o pochodzeniu iroszkockim został w ten sposób zastapiony biskupem Aronem z Nadrenii. Ujęcie to harmonizuje w pełni z poglądami współczesnych mediewistów, według których sakrę biskupią otrzymał on w Kolonii, ale nie był wcześniej związany ze środowiskiem leodyjsko-kolońskim. Aron nowobaśniowy umiera - tak jak przypuszczają historycy - w 1059 r., wbrew jednak tradycji kościelnej nie 9 X, lecz w wigilię wspomnienia św. Jakuba, czyli w nocy z 24 na 25 VII (zob. A. Witkow s ka, Aron. Hasło w: Encyklopedia katolicka. T. 1. Red. F. Gryglewicz, R. Łukaszyk, Z. Sułowski. Lublin 1995, k. 947). 
9 Dopisek wzdłuż lewego marginesu k. 1v.

10 Przed ślubem $z$ Janem Erdmanem we wrześniu 1945 i związaną z tym zmianą nazwiska Marta Wańkowiczówna sporo publikowała: w latach 1936-1939 w „Kurierze Porannym”, „Narodzie i Państwie”, „Chwili”, „Nowej Kuźni Młodych”, „Płomyku”, a w latach 1940-1945 m.in. w „Wiadomościach” (Londyn), „Polsce Walczącej”, „Tygodniku Polskim” (Nowy Jork). W roku 1941 w Chicago ukazały się wspomnienia M. W ańk ow i c zó w ny z września 1939: W szpitalu pod dwoma okupacjami. (Pamiętnik polskiej siostry miłosierdzia).

11 Dopisek wzdłuż lewego marginesu k. 1r.

4

Drogi Janku,

México, 16/III [19]45

Zasyłam Pani Marcie i Tobie najserdeczniejsze życzenia $\mathrm{z}$ okazji zbliżających się świąt Wielkiej Nocy.

Pamiętasz naszą wspólną Wielkanoc sprzed dwu lat?... Śpiew Kozioła ${ }^{1}$, Irena Wasilewska ${ }^{2}$ grała na fortepianie, sowieckie „szampanskoje” w naszym pokoju prasowym, oświetlonym jedynie przez blask lamp grającego radia, a potem dramatyczny telefon Ludwika [Seidenmana] z Moskwy, natychmiastowe wytrzeźwienie Gackiego ${ }^{3}$ i „Jezus, Maria!” Freyda 4 ... i ruch wtajemniczonych aż do rana po całej Ambasadzie... Ciekawym, kto dziś - po wyjeździe korpusu dypl[omatycznego] do Moskwy ${ }^{5}$ - rezyduje w naszym kujbyszewskim ambasadzkim gmachu...

Przeczytałem przed chwila 15-ty numer „Polish Facts and Figures” ${ }^{-}$- świetny!... Słyszałem też, że na Konferencji Panamerykańskiej ${ }^{7}$ tu u nas ktoś z potentatów prasy półn[ocno]-ameryk[ańskiej] miał ogromnie chwalić „\{Polish $\}^{8}$ Facts and Figures", jako najlepsze $z$ tego typu wydawnictw na całym może kontynencie...

Kister zapowiedział mi tajemniczo jakaśs depeszę od Ciebie, której nie dostałem... Kister przeczytał już 2-gi tom Srebrn[ych] Orłów (ja sam jeszcze 2-go tomu nie dostałem) - czy P. Marta już to czyta? Ciekawym, jak jej się podoba...

Chciałbym już jednak najprędzej przystapić do realizacji swego najistotniejszego celu przyjazdu do Meksyku: powieści o doñi Marinie ${ }^{9}$... Kłopot tylko, że ani w źródłach historycznych, ani w typie psychicznym współczesnej Meksykanki, ani w opinii fachowców, $\mathrm{z}$ którymi często na ten temat rozmawiam - nie mogę - jak dotąd - znaleźć potwierdzenia swojej koncepcji Mariny, jako „potężnej indywidualności["], nie tylko w sensie czaru zewnętrznego, ale i osobowości psychicznej i umysłowej, przerastającej swoich mistrzów, konkwistadorów hiszpańskich, i patrzącej wzgardliwie na tych, których początkowo uważała za bogów...

\{Przy okazji powiedz Krysi, że ucieszyłem się bardzo jej depeszą, ale jakoś nie mogę doczekać się zapowiedzianego listu...

Jak się mają panie Marysia i Irena?...

Ściskam Ciebie bardzo serdecznie,

Teodor Parnicki\} ${ }^{10}$

Pożółkła karta papieru średniej grubości, o wymiarach $21 \times 27,5 \mathrm{~cm}$, zapisana obustronnie ciemnogranatowym atramentem. Pismo równe, szeroki margines lewy na obu stronicach; na lewym marginesie karty verso dopisek w układzie pionowym (5 linijek).

$1 \quad$ Tadeusz Ko zi oł (zm. 1983) pracował w Wydziale Opieki; w 1944 r. razem z Parnickim mieszkał w pensjonacie w londyńskim Kensington; około 1948 r. wyjechał do Stanów Zjednoczonych i zamieszkał w New Brunswick w stanie New Jersey. 
Irena W a silew s ka (zm. ok. 1980) - prawniczka; żona Stefana Gackiego; po wojnie wraz z mężem wyjechała do Stanów Zjednoczonych; autorka wspomnień Za winy niepopetnione (Rzym 1945).

3 Stefan Gacki (1901-1984) - poeta, publicysta; w 1926 r. ukończył prawo na Uniwersytecie Warszawskim; na początku 1941 r. dyrektor Wydziału Wschodniego Ministerstwa Spraw Zagranicznych; w latach 1941-1943 pierwszy sekretarz Ambasady RP, kierownik Wydziału Opieki; od 1952 r. przebywał w New Jersey w Stanach Zjednoczonych; pisał komentarze polityczne dla Rozgłośni Polskiej Radia Wolna Europa; współpracował z „Nowym Dziennikiem”. Po wojnie wydał m.in. Rozmyślania. Wiersze wybrane 1924-1970 (1971), Rozmyślań część trzecia 1969-1975 (1975), Wiersze dla Ireny - rozmyślań część czwarta (1979).

4 Emanuel F r ey d-pierwszy sekretarz Ambasady RP, zastępca delegata Ministerstwa Pracy i Opieki Socjalnej, koordynator opieki i szef Biura Opieki.

5 W roku 1945 korpus dyplomatyczny wrócił z Kujbyszewa do Moskwy.

6 „Polish Facts and Figures” - pismo Polish Information Center, redagowane przez Jana Erdmana, przestało wychodzić wraz z likwidacją PIC (numer 15 ukazał się $z$ datą 12 III 1945).

7 W lutym i marcu 1945 odbyła się w Meksyku konferencja Unii Państw Amerykańskich, której uczestnicy opowiedzieli się za maksymalną samodzielnością ruchu panamerykańskiego $\mathrm{w}$ ramach mającej powstać światowej organizacji. Większość postulatów państw Ameryki Łacińskiej nie została jednak przyjęta na konferencji założycielskiej Organizacji Narodów Zjednoczonych w San Francisco (czerwiec 1945).

8 Dopisek nad linią tekstu głównego.

9 Malintzin (ok. 1505 - 1529 lub 1551), znana też jako La Malinche lub doña Marina (hiszpańskie imię przyjęte na chrzcie) - tłumaczka i towarzyszka życia Hernána Cortésa; Malintzin należy do najważniejszych postaci kobiecych w twórczości Parnickiego. Powieść o niej planował pisarz już $\mathrm{w}$ pierwszej połowie lat trzydziestych, co przedstawił w dwóch listach skierowanych do swego dawnego harbińskiego mentora i opiekuna, Konstantego Sy m o n o le wi c za (1884-1952); w liście z 12 V 1932 tak opisywał swój literacki projekt: „wielka powieść o konkwiście z 1519 i o pewnej kobiecie pt. Doña Marina - hołd złożony aryjskiemu duchowi i aryjskiej kulturze... doblesti [t]. „dzielności”, „waleczności”] i woli człowieka, który umiłował nieskończoność dali... wreszcie wiecznej kobiecości... jej pięknu, triumfującemu nawet u sprzedającej swe ciało niewolnicy..." Bardziej szczegółowo przedstawił Parnicki planowana powieść w liście z 15 VII 1934: „powieść miała być odwróceniem "dziejów grzechu": kobieta, traktowana jako rzecz, niewolnica, w najniższym upodleniu się znajdująca - przez miłość i w kontakcie z europejsko-chrześcijańską cywilizacją rozwija się, doskonali, podnosi się duchowo - a będąc naturą subtelną i bogatą, wyrasta niebawem nie tylko ponad otoczenie, ale ponad tych, którzy zrobili z niej człowieka z rzeczy... moralnie, duchowo, a nawet w zakresie inteligencji przerasta tego, który roztoczył przed nią tę drogę rozwoju... Przerasta Corteza... Doña Marina więc rozwija się i doskonali pod wpływem tej chrześc[ijańsko]-europejsk[iej] cywilizacji - z drugiej zaś strony sama ona roztacza urok nieprzeparty na wszystko, co ja otacza: ją, nałożnicę Corteza, uczci w chwili największego heroizmu moralnego i humanitarnego, jako chrześcijankę doskonała - mnich, o. Olmedo; urokowi jej i wpływowi humanitarnemu podda się okrutny, zimny i cyniczny Alvarado, mający przecież piękną żonę - Indiankę; ją na próżno będzie prosił o zostanie panią bogatego zamku w Hiszpanii ten, co ją niegdyś lekceważył, jako brankę indyjską - pierwszy alkad Vera Cruzu - Puertocarrero, do niej ostatnią swą myśl skieruje zbuntowany przeciw Cortezowi, na krótko przed nieoczekiwanym ścięciem - w sybarytyzmie pogrążony Olid - a i sam Cortez nie tylko fizycznie będzie ją kochać, ale będzie ją podziwiać i drażnić go będzie coraz to wyższa jej doskonałość, aż zechce jej się pozbyć...”

Planowana przez Parnickiego powieść miała ukazać drogę ewolucji duchowej kobiety, która, zetknąwszy się z nowa, nieznaną cywilizacją, stanęła wobec konieczności wielu przewartościowań i w końcu przyjęcia nowego, europejsko-chrześcijańskiego systemu wartości. Pisze T. Pa rni cki: „Taką się staje Marina w drodze powolnego rozwoju - ona, która w Choluli będzie jeszcze wielbić Corteza za wymordowanie całego niemal miasta i dziwić się będzie, że nie układa piramidy z czaszek - ona rzuci mu w twarz swą pogardą w dniu śmierci Gwatemozina - ona, nie biedna, dzika indyjska branka, ale ta, której Cortez w piękne wieczory w Tlaxcali opowiadał o rycerskiej szlachetności i wspaniałomyślności Aleksandra Wielkiego, Ferdynanda Świętego i Cyda..." (list z 15 VI 1934). Postać Mariny pojawia się w części 3 Nowej baśni (Labirynt, 1964) oraz, jako motyw nie do końca zrealizowany w twórczości pisarza, w autotematycznej Opowieści o trzech Metysach (1994). 
5

México, 5/IV [19]45

Drogi Janku,

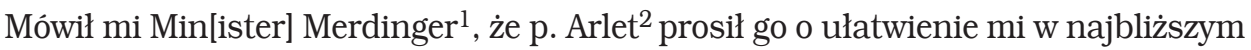
czasie wyjazdu do N[ew] Yorku w związku z projektem wydania Sr[ebrnych] Orłów.

Pisałem do p. Arleta z prośbą o wystaranie mi się przez Ambasadę w Departamencie Stanu wizy dypl[omatycznej] oraz o ustalenie z p. Kisterem, kto ma pokrywać koszta mojego przelotu w obie strony i pobytu w N[ew] Yorku - i o przekazanie mi części przynajmniej tej ustalonej kwoty do Meksyku, nie zaznaczyłem jednakże, że zależy mi na tym, aby wrócić do Meksyku koło 15 maja, jako że w pobliżu tego terminu mam wygłosić po hiszp[ańsku] pod patronatem meksyk[ańskiego] „PEN Clubu" odczyt o 50-cioleciu Quo Vadis ${ }^{3}$.

Bądź więc łaskaw, powiedz p. Arletowi, że zależy mi na tym, ażeby umożliwiono mi przybycie do N[ew] Yorku koło 20-25 kwietnia. O c z e ku je wi a d o m oś c i w tej sprawie.

I jeszcze jedno: bądź łaskaw, zastanów się, czy warto urządzić po polsku w N[ew] Yorku (wzgl[ędnie] też w innych ośrodkach o dużym skupieniu Polaków) mój odczyt jubileuszowy „50-ciolecie Quo Vadis”, o charakterze popularnym, a nie ekskluzywnym (za zaproszeniami), jak to było z odczytem za mojej poprzedniej u Was bytności. Ze względu na zbieżność rocznic mógłbym rozszerzyć temat na „50-ciolecie $Q u o$ Vadis i Faraona". Czy zająły się tym PIC, czy Polski Instytut Naukowy ${ }^{4}$ ?

Cieszę się myślą, że może już nie za długo będę miał okazję zobaczenia Ciebie. Czy Ludwik [Seidenman] przyjechał? Czy w ogóle przyjeżdża?

Pozdrawiam bardzo serdecznie Panią Martę i Ciebie - proszę o wiadomości, ewent[ualnie] o telegram.

\section{Teodor}

Pożółkła karta papieru średniej grubości, o wymiarach $21 \times 27,5 \mathrm{~cm}$, zapisana obustronnie ciemnogranatowym atramentem, pismo równe, szeroki margines lewy. W prawym górnym rogu karty recto ukośny dopisek ołówkiem ręką adresata, Jana Erdmana: „Odpowiedziałem na 5 listów 16 IV 45”.

1 Zygmunt M e r d in ge r (1890-1958 [lub 1959]) - dyplomata; w latach 1922-1927 konsul generalny RP w Królewcu; od 1928 do 1931 r. konsul generalny, a w latach 1931-1936 poseł RP w Meksyku (od 1933 r. także w Kolumbii i Wenezueli); od 1937 do 1939 r. radca Ambasady RP w Londynie; od 1940 do 1945 r. znów poseł RP w Meksyku; wydał w swoim opracowaniu Meksyk (1936).

2 Wiesław Arlet (1907-1988) - dyplomata, w pierwszej połowie lat trzydziestych był zatrudniony w konsulacie RP w Berlinie; w latach 1937-1939 radca Komisariatu Generalnego w Gdańsku; w latach 1939-1941 pierwszy sekretarz i radca legislacyjny Ambasady RP w Moskwie-Kujbyszewie; już na początku sierpnia 1941 wyleciał do Moskwy, aby przygotować podstawy działalności polskiej placówki, a także zorientować się w możliwościach pomocy polskim obywatelom w ZSSR i w szansach stworzenia wojska polskiego; w pierwszych dniach września 1941 uczestniczył w złożeniu przez ambasadora Stanisława Kota listów uwierzytelniających na Kremlu; był upoważniony do osobistych kontaktów z przedstawicielami władz ZSSR; jako że strona polska nie mogła protokołować rozmów, pełnił funkcję sekretarza-tłumacza opracowującego po powrocie do Ambasady sprawozdania $z$ rozmów; po sowieckiej prowokacji, mającej na celu wykazanie, że był on zamieszany w działalność szpiegowską polskich placówek terenowych, musiał w połowie $1942 \mathrm{r}$. na żądanie Komisariatu Spraw Zagranicznych opuścić Ambasadę; w latach 1942-1945 radca Ambasady RP w Waszyngtonie; po wojnie pracował w Departamencie Stanu USA; osiedlił się na Florydzie. 
3 Po raz pierwszy odczyt z okazji 50-lecia Quo vadis wygłosił Parnicki w czerwcu $1944 \mathrm{w}$ „Ognisku Polskim" w Londynie.

4 Chodzi zapewne o Polski Instytut Naukowy w Ameryce, placówkę naukową i dydaktyczną, która została założona w 1942 r. w Nowym Jorku jako emigracyjna kontynuacja Polskiej Akademii Umiejętności; wśród założycieli byli m.in. Bronisław Malinowski, Oskar Halecki, Tadeusz Kucharzewski; do końca wojny Instytut był subwencjonowany przez rząd RP w Londynie; w 1945 r. nie podporządkował się rządowi w Warszawie.

6

México, 20/IV [19]45

Drogi Janku,

Martwi mnie i niepokoi głuche milczenie Twoje i Pani Marty. Rozumiem, że każdy z nas ma dzisiaj dużo osobistych trosk i kłopotów, ale przecież jedną z podstawowych cech przyjaźni jest właśnie potrzeba dzielenia się tymi troskami.

Chciałbym bardzo Cię zobaczyć, mielibyśmy bardzo dużo z sobą do omówienia - liczyłem się $\mathrm{z}$ tym, że Cię zobaczę koło 25 kwietnia, ale odnośnie [do] sprawy mojego wyjazdu do N[ew] Yorku w związku z projektem wydania Sr[ebrnych] Orłów zaległa kompletna cisza. Jeszcze w końcu marca, zaraz na lotnisku, powiedział mi P. Min[ister] Merdinger, że p. Arlet go prosił o ułatwienie mi przyjazdu na parę tygodni do N[ew] Yorku. Oczywiście, wyjazd mi p. Merdinger ułatwi, ale ponieważ nie jest to podróż służbowa w interesach naszego Poselstwa w Meksyku Poselstwo to nie może pokrywać kosztów podróży.

Napisałem więc i do p. Wiesława [Arleta], i do p. Kistera, aby uzgodnili, kto ma pokryć te koszta i aby po uzgodnieniu załatwili przekazanie mi pieniędzy na przelot w obie strony i na utrzymanie przez 2-3 tygodnie w New Yorku. Ale żadnej odpowiedzi! Zależy zaś mi na na ty c h mi a s to w o ś c i tej podróży, gdyż w drugiej połowie maja muszę być w Meksyku: mam tu objazd odczytowy na temat „50-ciolecia Quo Vadis” (po hiszpańsku).

Bądź łaskaw, interweniuj w tej sprawie: niech mi p. Arlet albo p. Kister zadepeszują: tak czy nie - jeżeli tak, niech równocześnie przekazane mi zostaną pieniądze na podróż. Chciałbym być w N[ew] Yorku przed końcem kwietnia. I pisz - pisz o sobie, o P. Marcie! Czy ona przeczytała 2-gi tom Srebrnych Orłów? Co z Ludwikiem [Seidenmanem]? Czy wrócił do N[ew] Yorku? Jeżeli nie, to kiedy wraca?

Równocześnie wysyłam do Ciebie list dla prof. Lednickiego ${ }^{1}-$ nie znam jego adresu. Bądź łaskaw, postaraj się, \{aby list ten bezzwłocznie mu doręczono. Przepraszam Cię za fatygę i z góry dziękuję. Osobiście mam dużo zmartwień i komplikacyj - życiowych i psychicznych. Chciałbym być choć krótko z Tobą, mówić z Tobą. Oboje Was pozdrawiam bardzo serdecznie.

\section{Teodor $\}^{2}$}

Pożółkła karta papieru średniej grubości, o wymiarach $21 \times 27,5 \mathrm{~cm}$, zapisana obustronnie jasnoniebieskim atramentem; pismo równe, luźne, nieco szerszy lewy margines, na odwrocie dopisek marginalny w układzie pionowym (5 linijek). W lewym górnym rogu karty recto nieczytelny dopisek „do góry nogami”, czerwoną kredką, prawdopodobnie słowo: „obojętny”.

$1 \quad$ Wacław Lednicki (1891-1967) - historyk literatur słowiańskich, krytyk literacki, autor wspomnień; w latach 1926-1928 wykładowca języków i literatur słowiańskich na Wolnym Uniwersyte- 
cie w Brukseli; w 1928 r. został mianowany profesorem Uniwersytetu Jagiellońskiego i do r. 1930 prowadził jedyną w Polsce Katedrę Historii Literatury Rosyjskiej; w dalszych latach łączył pracę na uniwersytetach w Brukseli i Krakowie; wiosną 1940 wyjechał przez Belgię, Francję, Hiszpanię i Portugalię do Stanów Zjednoczonych; w sierpniu 1941 rozpoczął wykłady na Columbia University w Nowym Jorku, jednocześnie w latach 1940-1944 był profesorem w Zakładzie Slawistyki na Harvard University w Cambridge, w latach 1944-1962 na University of California w Berkeley; był współzałożycielem Polskiego Instytutu Naukowego w Nowym Jorku oraz Polskiego Towarzystwa Naukowego na Obczyźnie. Na początku lat trzydziestych Parnicki myślał o asystenturze u Lednickiego na UJ. 17 X 1933 pisał do Stanisława Kota po jego sugestii, że mógłby się starać o zatrudnienie na uniwersytecie w Rydze:

„Przyznam się, że objęcie katedry literatury rosyjskiej byłoby dla mnie wprost wymarzoną przyszłością i bardzo gorąco tego pragnę, uważając zresztą, że może mam pewne do tego dane, może większe niż kto bądź w Polsce (tak zresztą stwierdził Pan) - nie wyobrażam jednak sobie zupełnie, jak by się dało przeprowadzić faktycznie, a w szczególności formalnie. [...]

W r. 1931 był we Lwowie p. prof. Lednicki; mówiłem z nim, była mowa o ewentualnym moim przeniesieniu się do niego, do Krakowa, o asystenturze, o stypendium itd. - ale nic z tego nie wyszło. Może by Pan mógł z prof. Lednickim porozumieć się co do mojej przyszłości?...” („Jak co roku, tak i tym razem $w$ dzień wigilijny...”, s. 231-232).

2 Dopisek wzdłuż lewego marginesu k. $1 \mathrm{v}$.

7

Written in Polish

México, 24/IV [19]45
Mój adres prywatny: Paseo de la Reforma

$237-2$

México D. F.

Drogi Janku,

Dziś dostałem nareszcie listy, Pani Marty i Twój. Cieszę się nimi bardzo. Brak mi was bardzo. Atmosferę wokół siebie mam raczej przyjazną i życzliwą, ale nie jest to środowisko, które by było dla mojej psychiki owym niezbędnym „powietrzem do oddychania”. Traktuje się mnie tu jako miłego raczej, ale lekkomyślnego dziwaka i histeryka - taki zresztą chyba jestem naprawdę...

List Twój wyjaśnił mi, jak naprawdę się przedstawia sprawa mojego przyjazdu do N[ew] Yorku. Więc wcale się nie przedstawia... Od razu wiedziałem, że Poselstwo mi kosztów podróży nie pokryje - zresztą otrzymawszy dziś Twój list, raz jeszcze rozmawiałem $z$ Min[istrem] Merdingerem... Jest on mi raczej bardzo życzliwy, choć - oczywiście - nie zastąpi mi ani Kota, ani Neumana - ale oświadczył, czego oczekiwałem: nie ma możliwości, aby wysłano mnie choćby jako kuriera dyplomatycznego do Stanów. O ile więc Kister nie zechce zaryzykować tych kilkuset dolarów - o ile „węch” jego, na ogół świetny, nie powiedział mu, że to ryzyko się opłaci, gdy wyda Srebrne Orły - no, to więc sprawa jest prosta i jasna: n i e p r zyja dę.

Piszesz o możliwościach czy raczej na razie tylko perspektywach mojego przeniesienia się do Stanów, o lektoracie literatur i języków słowiańskich... Ja też, jak i Ty, nie sądzę, aby Kister istotnie miał możność realizowania tych rzeczy i musieliby - prócz niego - zainteresować się tym Lednicki i Halecki ${ }^{1}$ - co najmniej!... Ale zobaczymy... Jeśli chodzi o samo meritum sprawy, na któreś słusznie zwrócił uwagę: przyjechałem do Meksyku jako do krainy tyloletnich marzeń, aby zrealizować młodzieńczy jeszcze pomysł powieści o Cortésie ${ }^{2}$ i uroczej Azteczce, doñi Marinie... 
byłoby nonsensem, ba, upokorzeniem i klęską, niezrealizowanie tego planu. Czas jakiś więc muszę tu jeszcze zostać... mu s z ę...

Dalej: wątpię, czy kiedykolwiek zdołam naprawdę dobrze opanować angielski... zacząłem się go uczyć, mając 12 lat $^{3}$ - czytałem dużo w tym języku przez całe życie (co prawda, mało miałem możliwości rozmawiania - ale przecież pół roku siedziałem w Anglii - i co? niewiele więcej dziś umiem niż 20 lat temu) - i oto dziś mój hiszpański już dorównuje prawie całkowicie memu angielskiemu, choć uczę się go dopiero 8 miesięcy... Widocznie łatwiej mi adaptować się do świata kultury łacińskiej... Ty, Janku, znasz mnie stosunkowo bardzo dobrze, więc chyba zgodzisz się ze mna, że p sy ch i czn i e pasuję więcej do świata łacińskiego niż anglosaskiego... nie wolno mi z tym się nie liczyć, mimo że wierzę, iż kultura intelektualna i artystyczna ma w Stanach przed soba fantastycznie wprost wspaniałe perspektywy... że „Jankesi” będa prawdziwymi dziedzicami wielkich tradycyj kulturalnych starej - dziś tak bardzo, bardzo biednej, zmęczonej, wykoszlawionej - Europy... że intelektualista i artysta europejski w Stanach mo że żyć świetnie, a w Ameryce Łacińskiej ledwie, ledwie... Ale wydaje mi się, że mój typ myślowy i psychiczny tam - u Was - nie będzie - powiedzmy: pasował... No, ale zobaczymy... Na razie ani tu, ani tam żadnych projektów realnych... Zabawne, że psychicznie (choć nie myślowo) najbardziej pasuję chyba... wiesz, do czego?... - jeżeli chodzi o zagranice - chyba do Rosji, a i to do tej raczej, co się skończyła w r. 1917... a najściślej mówiąc, do tej, co trwała od lutego do października $1917^{4}$... I może do Rosji \{Dostojewskiego ${ }^{5}$, z problemami religijno-metafizyczno-psychopatologicznymi.... ${ }^{6}$

Dziękuję Ci za ostrzegawcze uwagi co do mogącej nas już bardzo prędko czekać przyszłości ${ }^{7}$. Jestem - psychicznie, nie materialnie oczywiście i nie w sensie zaradności-przygotowany na wszystko. I to od dawna, od tej nocy-pamiętasz? po śpiewach, po szampanie... i - gdy Ludwik [Seidenman] o wpół do czwartej nad ranem zadzwonił z Moskwy do Kujbyszewa... ${ }^{8}$ Pisząc o sobie, piszesz o „przetrwaniu na ziemi”. Ja, Mój Drogi, mam w krwi wrogość do „ziemi”, do przyrody... czy Pani Marta przypomina sobie z 2-go tomu Srebrn[ych] Orłów koncentryczny atak Romualda i Gerberta na przyrodę? ${ }^{9} \mathrm{~W}$ tym jestem cały ja! Może to dziedziczne? ${ }^{10}$... Zresztą, Mój Kochany, w Tobie jest tyle siły \{psycho\} ${ }^{11}$-biologicznej, przy tym masz z sobą kogoś, kto Ciebie bardzo kocha i kogo Ty bardzo kochasz... Jedno i drugie to takie ważne, gdy chodzi o "przetrzymanie”... A ja jestem b a r d zo sam i bardzo zmę czony. Wiesz, że ciagnę za soba przez 40 blisko lat rozmaite obciążenia, dwoistości, urazy, skrzywienia... Toż to widać od razu, gdy się czyta uważnie, bardzo uważnie Srebrne Orty... ma to jednak i pewien plus: nie umiałbym być Tobą czy Ksawerym [Pruszyńskim] ${ }^{12}$, czy zmarłym Adolfem [Bocheńskim] $]^{13} \mathrm{w}$ wiadomych okolicznościach (nie umiałbym i nie chciałbym zreszta) bliższy mi od waszego jest typ psychiczny i myślowy Gandhiego ${ }^{14}$ i w kategoriach tego typu stać mnie i na odwagę, i na pewną siłę: przekonałem się o tym choćby we Lwowie na przełomie lat $1939-40^{15}$ i potem ${ }^{16}$ aż do paktu lipcowego ${ }^{17} \ldots$ Nie wiem, czy nie przesadnie oceniam wartość swej twórczości, ale poza twórczością nie widzę w sobie absolutnie żadnej już wartości, dla mnie samego nawet zasługującej na zabiegi, by za w s zelką c en ę „przetrwać”... Życie ma sens o tyle tylko, o ile można żyć tak, jak się chce żyć... Jeżeli nie można by ć s o b a, to po co by ć?!

No, ale dość teoretyzowania z pogranicza psychopatologii i metafizyki... Ja mam 
w sobie inny jeszcze męczący problem: wyobraź sobie, jakbym się czuł, gdyby Gronowicz ${ }^{18}$ podjął mój temat Cortésa i Mariny i po swojemu go zrealizował, i zaczęłyby się wołania: „No, nareszcie ktoś to zrobił!!” Rozumiesz chyba paralelę?... chodzi o mój stosunek do sprawy: Polska-Rosja... Podobno stara Helena [Usijewicz] ${ }^{19}$ myślała, gdyśmy wyjeżdżali z Czapajewskiej ${ }^{20}$ - że ja zostanę... Nie zostałem, nie zostałbym, nie mogłem i nie chciałem zostać - ale to znamienne, że ona wyczuwała, iż z nas wszystkich dla mnie to był najcięższy dramat... Miałem swoje koncepcje - ileż razy przedkładałem je i Profesorowi [Kotowi], i zaprzyjaźnionym ze mna dmowszczykom ${ }^{21}$ - nie chciano mnie słuchać, nazywano to „literackimi fantazjami”... Może to i były fantazje... Ale dziś in ni realizują rzekomo to samo, czego ja pragnałem... Ale jak realizują??! Co z tego wychodzi?! A mogło być inaczej... mogło...22

List ten jest przeznaczony dla was obojga: dla Pani Marty i Ciebie. Ale pokaż go i Ludwikowi [Seidenmanowi]. Zreszta, on mi jest winien jeden list, i to bardzo ważny dla mnie: miał podzielić się ze mną swymi wrażeniami z lektury Srebrnych Orłów: nie dziwcie mi się i nie śmiejcie się ze mnie, że tak chciwy jestem opinii o swojej książce. W Polsce, gdy wyszedł Aecjusz, sypały się recenzje: były i ostre, i zjadliwe, ale przeważnie pochlebne, często entuzjastyczne... A teraz głucha cisza!! Więc nie dziw, że żebrzę o sądy przynajmniej tych \{paru osób, które się literaturą naprawdę interesuja i których smak i opinię bardzo sobie cenię. Nie wiem, czy zobaczymy się kiedy jeszcze, a chciałbym. Bardzo. Ściskam serdecznie Ciebie i Ludwika [Seidenmana]. Pani Marcie ręce całuję.

Teodor $^{23}$

\{Listu Krysi nie otrzymałem. Żal... Może ona jeszcze raz napisze? może wyśle poleconym? I to na prywatny mój adres... i Ty, i Ludwik - też piszcie chyba na prywatny. $\}^{24}$

Dwie pożółkłe karty papieru średniej grubości, o wymiarach $21 \times 27,5 \mathrm{~cm}$, zapisane obustronnie ciemnogranatowym atramentem; pismo równe, gęste, wąski margines lewy, zapisany w układzie pionowym adnotacjami (karta 1 recto: 4 linijki, karta 2 verso: 4 linijki). Dodatkowo dopisek na karcie 2 recto na marginesie lewym w układzie poziomym w górnej części karty (10 krótkich linijek). Karta 2 recto oznaczona w lewym górnym rogu rzymską cyfrą II. Układ adresów i dat na początku listu odzwierciedla zapis rękopiśmienny.

1 Oskar Ha le c ki (1891-1973) - historyk, badacz epoki jagiellońskiej i dziejów Bizancjum; działacz emigracyjny; od 1919 do 1939 r. profesor Uniwersytetu Warszawskiego; w latach 1929-1939 dodatkowo wykładał w Szkole Nauk Politycznych w Warszawie; wybuch drugiej wojny światowej zastał go w Szwajcarii, skąd udało mu się przedostać do Francji; w Paryżu zorganizował Polski Uniwersytet na Obczyźnie; po upadku Francji wyjechał - przez Hiszpanię i Portugalię - do Stanów Zjednoczonych; w latach 1940-1942 wykładał historię Europy Środkowo-Wschodniej w Vassar College w Poughkeepsie (w pobliżu Nowego Jorku), a w latach 1944-1961 kierował Katedrą Europy Wschodniej na jezuickim Fordham University w Nowym Jorku; w 1942 r. należał do założycieli Polskiego Instytutu Naukowego w Ameryce (w latach 1942-1952 był jego dyrektorem, w latach 1953-1962 prezesem, a od r. 1964 - prezesem honorowym); w swojej działalności naukowej współpracował $\mathrm{z}$ wieloma innymi amerykańskimi uniwersytetami.

2 Hernán Corté s (ok. 1485-1547) - konkwistador hiszpański, zdobywca Meksyku.

3 Parnicki zaczał się uczyć angielskiego w Gimnazjum im. Henryka Sienkiewicza w Harbinie (Chiny). Po przyjeździe do Lwowa utrzymywał kontakt korespondencyjny z nauczycielką języka, Rosjanką, Wierą Tukerkes. 
4 Rewolucja lutowa wybuchła w Rosji 23 II (8 III) 1917 pod hasłami likwidacji monarchii i przeprowadzenia demokratycznych wyborów do Zgromadzenia Ustawodawczego, które miało określić przyszły ustrój państwa, a także pod hasłami amnestii, wolności prasy i umożliwienia swobodnej działalności stowarzyszeń i partii politycznych; rewolucja załamała się w wyniku przewrotu bolszewickiego w październiku 1917.

5 Parnicki wracał do powieści Dostojewskiego przez całe życie. Czytał je na ogół w oryginale. Cenił sobie tylko niektóre ich przekłady na inne języki, w tym na język polski. W liście do A. Wata z 7 III 1961 pisał (cyt. za: „Mało kto z nas wszystkich jeszcze żyjacych daje mi to poczucie ciagtości polskiej [...] literatury XX wieku". Listy Teodora Parnickiego do Aleksandra Wata. Oprac. P. G or l i ń s k i - K u c i k. „Śląskie Studia Polonistyczne” 2013, nr 1, s. 247): „Przeczytałem właśnie - po raz pierwszy w życiu - wydane przez PIW polskie przekłady dwu książek Dostojewskiego. Otóż, moim zdaniem, P a ń s c y Karazamowy w sensie polszczyzny i oddania "dostojewszczyzny" niesłychanie górują nad Zbrodnia i kara Jastrzębca-Kozłowskiego. Ale nie o tym (co wyżej) chciałem do Pana pisać, tylko na temat "ciaśniejszy": Legenda o Wielkim Inkwizytorze, znana mi w oryginale prawie na pamięć, jest w Pańskim spolszczeniu arcydziełem rytmiki (muzyki) i retoryki, i mocy dramatycznej, jakie zadziwiająco (bo przecież poza ty m D[ostojewski] jest raczej niedbały, chwilami "niechlujny" stylowo) wyróżniają tych właśnie kilkadziesiąt stron oryginału. Znam poza tym Braci Kar[amazow] w przekładach i angielskim, i hiszpańskim; i tu, i tam - Legenda Iwana jakże jest żałosna w porównaniu z polską: Pańską!"

6 Dopisek na lewym marginesie k. 2v.

7 Chodzi o spodziewane cofnięcie uznania rządu londyńskiego ze strony Stanów Zjednoczonych, Wielkiej Brytanii i innych państw, równoznaczne $\mathrm{z}$ koniecznością likwidacji jego przedstawicielstw, m.in. w Meksyku, co rzeczywiście nastapiło na początku lipca 1945. Poseł RP w Meksyku Zygmunt Merdinger otrzymał notę datowaną na 9 VII 1945, uznająca jego misję za zakończoną.

8 Wieczorem 25 IV 1943 wiceprzewodniczacy Rady Komisarzy Ludowych ZSSR Wiaczesław Mołotow wezwał ambasadora RP Tadeusza Romera i odczytał mu notę o przerwaniu przez RKL ZSSR stosunków z Rządem RP. Romer oświadczył, że przekaże to stanowisko rządowi, ale noty nie przyjmie, jako że jej adresatem winno być MSZ w Londynie. Wiadomość o zerwaniu stosunków dyplomatycznych do Ambasady RP w Kujbyszewie dotarła w nocy z 25 na 26 IV 1943.

9 Aron w drodze $\mathrm{z}$ Krakowa do Poznania wspomina rozmowę, jakiej był świadkiem w Rawennie, między mnichem Romualdem, założycielem kamedułów, a Gebertem z Aurillac, przyszłym papieżem Sylwestrem II, na temat demonicznej strony natury. Obaj uważali zgodnie, że tym silniej daje ona o sobie znać, im niżej w hierarchii bytów się znajduje. „Żadnej zaś duszy własnej nie posiada natura ziemi - życiem demonów, co w niej się czają, jedynie żyje!” Różnili się jednak strategią obrony. Romuald zalecał skrajną izolację od natury: „Uciekać, jak najdalej uciekać - poza mury grube i szaty grube, i podeszwy!" Natomiast Gebert proponował walkę, czyli zgłębianie zasad rządzących naturą i wykorzystanie ich dla dobra człowieka: „Ongiś prawnukowie Adama i Ewy w ciemnocie trwożnej oczu nie śmieli podnieść na słońce i gwiazdy - uszy zatykali, by nie słyszeć wycia wichrów i ryku fal morskich - gwiazdom i morzu, kamieniom i drzewom, krowom i jaszczurkom cześć, niby Bogu samemu, bluźnierczo oddawali! Ale minęły tysiąclecia i oto z drzewa buduje człowiek okręty, którymi po morzu huczącym dumnie, władczo żegluje - z kamienia pałace i świątynie przewspaniałe wznosi - krowy, konie i psy jemu służą, a nie on im - z wichru i grzmotu, z ryku lwa i świergotu ptasiego wyśmiewa się pieśnią i muzyką, stokroć piękniejszą niż wszystkie przyrody nierozumnej głosy, co go ongiś taka grozą potworną napawały... Nie pada już na twarz przed gwiazdami, ale naturę ich śmiało bada, sam im rozkazując: "Przybliżcie się do mnie». I przybliżają się. [...] Są głupcy ciemni, co powiadają: grzech to wnikanie w tajniki wszechświata przez Boga stworzonego. $\mathrm{Nie}$, nie grzech. Przeciwnie, żąda Mądrość Boża, by dowiodła natura człowiecza, iż niepodobna jest do owego sługi niegodnego, co talenty w ziemi zakopał - iż nie zagrzebała w cielesności zwierzęcej owej iskry Mądrości, miłosiernie Adamowi i Ewie pozostawionej... Dopiero bowiem wówczas, gdy niczym już chełpić się przed naturą człowieczą nie zdoła przyroda nierozumna, przez demony ciemne opętana - gdy pokona myśl ludzka ptaka, jak on w powietrze się wznosząc - rybę, jak ona pod wodę się zanurzając - błyskawicę, jak ona bez krzemienia jasność rozpościerając - dopiero wtedy, powiadam, rzeknie Mądrość Boża synom i córom Adama i Ewy: "Wróćcie na łono moje, otoście zaświadczyli, żeście obraz i podobieństwo moje «. I będzie to godzina pokusy najstraszliwszej: Pan Ciemności, który rzekł Adamowi i Ewie: „Bądźcie jako bogowie», szepnie synom i córom Ada- 
mowym: "Otoście już jako bogowie». I czekać będą duchy bezcielesne, świetliste i ciemne, co odrzeknie natura człowiecza na ów podszept szatański. Czy przytaknie pysznie: "Otośmy jak Bóg»! Nie, nie przytaknie. Nad ziemią i niebem, nad tajemnicami gwiazd i otchłaniami mórz panując szepnie: „Panie, czymeśmy przed Twoim obliczem? Prochem!»" (T. P a r n i c ki, Srebrne orty. Warszawa 1957, s. 469-471).

10 Jak wynika ze wspomnień pisarza, jego matka w sposób wręcz obsesyjny zabraniała mu chodzenia boso. Bezpośrednio po jej śmierci 10-letni Teodor zdobył się na swoistego rodzaju wyczyn: na prośbę i w towarzystwie przyjaciółek z sąsiedztwa przeszedł się bez obuwia po ulicach Ufy. „Podejrzewam, że to matka Jadzi i Iłły, która przecież powiedziała nawet kiedyś mojej matce, że ona mnie w ten sposób wypacza, zasugerowała swym dziewczynkom, ażeby mnie namówiły do próby przełamania w sobie oporów przeciw chodzeniu boso. Tak czy inaczej, zrobiłem [to] dla Iłły [...]; ze smutkiem i wyrzutem myślę też dziś, iżem się pokalał wówczas nielojalnością w stosunku do zmarłej matki” („Pamięć, władca [...] bezlitosny, wciaż i wciaż wskrzesza ponownie to, co minęło...” Fragmenty wspomnień Teodora Parnickiego. Odnalazł, oprac. i do druku podał T. Marki ew ka. „Pamiętnik Literacki” 2002, z. 2, s. 200). Motyw bosych stóp powracał wielokrotnie w twórczości Parnickiego, m.in. w powieści Tylko Beatrycze (1962).

Dopisek nad linią tekstu głównego.

12 Ksawery Pru szyń s ki (1907-1950), pisarz, publicysta i reporter; w latach 1941-1942 był attaché kulturalnym w Ambasadzie RP w Moskwie-Kujbyszewie; w latach 1942-1946 współpracował z londyńską „Nową Polską; w 1944 r. z 1 Dywizją Pancerną brał udział w bitwie pod Falaise; w latach 1945-1950 poseł Polski komunistycznej w Hadze; wydał książkę poświęcona pobytowi w ZSSR Russian Year. The Notebook of an Amateur Diplomat (New York 1944; wyd. polskie: Noc na Kremlu. Warszawa 1989).

13 Adolf Bocheńs ki (1909-1944) - pisarz i publicysta polityczny; studiował dyplomację w École des Sciences Politiques w Paryżu i prawo na Uniwersytecie Jana Kazimierza we Lwowie; publikował w „Buncie Młodych” i „Polityce”; jako żołnierz Brygady Podhalańskiej brał udział w bitwie o Narwik (1940), z Pułkiem Ułanów Karpackich bronił Tobruku (1941) i walczył pod Monte Cassino (1944); wśród współtowarzyszy broni cieszył się opinią człowieka o wielkiej odwadze; zginął 17 VII 1944 przy rozbrajaniu miny pod Ankoną.

14 Mahatma Gandhi (właśc. Mohandas Karamchand Gandhi) (1869-1948) - przywódca ruchu na rzecz niepodległości Indii, twórca państwowości indyjskiej; symbol walki bez przemocy. T. Pa rn ic ki w liście z 24 XI 1956 pisał do J. Stempowskiego: „Od dawna żywię wielką sympatię do współczesnego państwa Indii - postać Mankurasa w Końcu "Zg[ody] Nar[odów]" jest w dużym stopniu transpozycją tej właśnie sympatii w dziedzinę powieści historycznej..." (kopie listów T. Parnickie go do J. Stempowskiego z lat 1951-1967, przechowywanych w Muzeum Polskim w Rapperswilu, znajdują się w archiwum Instytutu Pamięci Narodowej - sygn. IPN BU 2889/218). Parnicki po zajęciu Lwowa przez Armię Czerwoną nie zaprzestał działalności jako sekretarz lwowskiego oddziału Związku Literatów Polskich. Z tego okresu zapamiętał go A. Wat (Mój wiek. Fragmenty rozmów Aleksandra Wata z Czesławem Miłoszem. T. 1. Kraków 2011, s. 305): „Zgłosiłem się do Ortwina, gdy tylko przyjechałem do Lwowa. W jego mieszkaniu był lokal dawnego Związku Literatów. Jak to się wtedy nazywało, Związek Zawodowy Literatów Polskich, Sekcja Lwowska, prezes Ortwin przyjmuje w takie i takie dni, sekretarz Parnicki o tej i tej godzinie. [...] Urzędował. Gdy założono ten orgkomitet, Ortwin dostał polecenie, aby rozwiązał Związek. Nie rozwiązał. Parę razy jeszcze u niego byłem, potem bałem się już chodzić, ze względu na niego i na siebie. Ale na początku, w dniach, kiedy miał przyjmować, siedział i czekał na interesantów. Interesantów tych było coraz mniej, bywali, przychodzili, ale coraz mniej. Parnicki też urzędował. Nie wstąpił do nowego związku”. W każdej chwili Parnicki mógł spodziewać się aresztowania. Po latach, w liście z 8 V 1980 pisał do H. Voglera: „Ja [...] już od końca października liczyłem się z tym, że będę aresztowany, m.in. $z$ powodu następującego odwiedził mnie w domu zupełnie mi nieznany Adam Polewka [...] i powiedział tak: "Okazaliście się, Parnicki, dobrym kolegą (ten zwrot - dobry kolega - odnosił się chyba do życzliwości, jaką - jako sekretarz oddziału lwowskiego - starałem się okazywać masowo przyjeżdżającym kolegom pozalwowskim [...]), więc my, literaci, przybysze spoza Lwowa, szczerze życzymy wam, ażebyście się jak najprędzej znaleźli w Paryżu..... $Z$ tej rady nie skorzystałem - nawet nie próbowałem skorzystać - z wynikiem Panu dobrze znanym..." (list znajduje się w prywatnym archiwum spadkobierców adresata). Parnicki został aresztowany w drugiej 
połowie stycznia 1940 i osadzony na Zamarstynowie. Współwięzień J. Ko w a le w s k i (Cela nr 60. „Wiadomości” 1950, nr 17, s. 2) tak go wspominał po 10 latach: „Parnicki sprawował wyraźny rząd dusz w celi nr 60 [!]. Cały dzień, chodząc od grupy do grupy, jak wędrowny retor, opowiadał "bajki" - najczęściej o Aecjuszu, "ostatnim Rzymianinie". A głód słowa w celi był nie mniejszy chyba niż głód chleba. [...] I Pochmurski [więzień kryminalny] zaspokajał [...] głód słowa. I on słuchał "bajek" Parnickiego. I ogromnie go szanował, w czym okazał dużą wyższość nad swoim większym kolegą z Kremla, który Parnickiego kazał zamknąć... Być może Pochmurski jakimś dziwnym instynktem wyczuwał, że siła Parnickiego nie $z$ tego jest świata i że nawet dyktaturze nie wolno gwałcić władzy słowa".

16 Opis więzienia w Horodni, do którego Parnicki trafił z Zamarstynowa, znajduje się we wspomnieniach W. Grubińskiego (Między młotem a sierpem. Londyn 1948, s. 60-61): „Po zamarstynowskiej małej celi poklasztornej kamera horodnieńska o dwu oknach wydawała mi się obszerna. Ze względu na ilość więźniów, ilość zmienną, od trzydziestu jeden do trzydziestu siedmiu osób, nie mieliśmy w niej luzu, ale nie byliśmy tak ściśnięci, jak w więzieniu na Zamarstynowie. I "umeblowanie" kamery było bogatsze. Dostaliśmy duży stół kuchenny, trzy czy cztery małe szafki na naczynia (oczywiście, za mało na tylu lokatorów), trzy proste stołki, któreśmy nazywali taboretami, wiadro na wodę do picia, dość dużą paraszę. Sienników nie starczyło dla wszystkich, więc sypiałem na swoim palcie zimowym. [...] Tak. Bez poduszki, na twardym, a gdy nadeszła zima, okryty ręcznikiem żyrardowskim i marynarką, ponieważ nie miałem koca, w ciężkim powietrzu, zatrutym przez oddechy i nie pachnacy pot tylu ciał ludzkich, spałem wyśmienicie. Budzono nas przed świtem, wyprowadzano po ośmiu do okropnego wychodka, rozdawano po sześćset gramów czarnego chleba, przeważnie dobrego, podawano wiadro herbaty, nie wiadomo $\mathrm{z}$ czego zrobionej, i szliśmy na czterominutowy spacer, w lecie po piachu, w zimie po śniegu i ślizgawicy, na wiosnę po błocie. Na podwórzu więziennym stały dwie krzywe latarnie naftowe, jedna z nich o okienku, które się nie domykało. Piętrowy stary mur otaczał podwórzec i łączył budynki. Więzienie miało przeszło sto lat i posiadało wdzięk małomiasteczkowości słowiańskiej, pochylone mury, niezdarne drzwi, ciężkie i skrzypiące, artretyczne spęczniałe schody, krótkie rynny, sterczące w bok, żeby odchlusnąć wodę jak najdalej od muru, tuż u głównego wyjścia bajoro i rynsztok, a wśród tego wszystkiego dozorcy NKWD”. Następnie Parnicki trafił do więzienia w Czernihowie, gdzie sąd okręgowy skazał go na 8 lat. Wyrok odbywał w Czernihowie, Nowogorodzie, Siewiersku i Kustanaju. Na wolność wyszedł na mocy amnestii 27 VIII 1941.

17 Chodzi o układ z 30 VII 1941 między Polską a ZSSR, przywracający stosunki dyplomatyczne między obu państwami, zerwane 17 IX 1939 w efekcie agresji Zwiąku Sowieckiego na II Rzeczpospolitą. Układ miał na celu wspólną walkę z III Rzeszą w ramach koalicji antyhitlerowskiej. W protokole dodatkowym ZSSR gwarantował „amnestię" dla obywateli polskich, którzy znaleźli się w więzieniach, łagrach i na zesłaniu w wyniku polityki represji stosowanej przez władze sowieckie na ziemiach II Rzeczpospolitej wcielonych do ZSSR.

18 Antoni Gronowicz (1913-1985) - poeta, prozaik, dramaturg, publicysta; w latach 1936-1938 pracował jako asystent na Wydziale Historii Uniwersytetu Jana Kazimierza we Lwowie; w r. 1936 organizował tzw. zjazd pracowników kultury; pisał w „Sygnałach” i „Lewarze”; w 1938 r. wyjechał jako stypendysta Funduszu Kultury Narodowej do Stanów Zjednoczonych; po wybuchu wojny pozostał tam na stałe; wykładał na uniwersytetach w Nowym Jorku i San Francisco; jego sztuki wystawiano na Broadwayu; autor książek biograficznych (o Fryderyku Chopinie, Piotrze Czajkowskim, Sergiuszu Rachmaninowie, Tadeuszu Kościuszce, Piastach polskich).

19 Helena U sijew i c z (1893-1968) - córka Feliksa Kona; sowiecka publicystka, parająca się m.in. krytyką literacką, kodyfikatorka tzw. realizmu socjalistycznego; przyjaźniła się z Wandą Wasilewską, tłumaczyła jej książki na język rosyjski; Parnicki odwiedzał ją podczas swego pobytu w Kujbyszewie. W Opowieści o trzech Metysach, z wyraźnym wątkiem autobiograficznym, bohater, alter ego pisarza, prowadzi rozmowę z postacią podającą się za Krzysztofa Villafanę z części 3 Nowej baśni: „[Krzysztof V.:] Spotykał się pan w jednym z pokojów "Grand Hotelu" z Heleną Usijewicz, córką słynnego ongiś Kona. Otóż ta właśnie pani (czy ściślej jeszcze mówiąc: towariszcz Je... Jelena Feliksowna) raz kiedyś - z panem rozmawiając - tak wyraziła się: "Gorąco proszę pana, ażeby o tym, co za chwilę powiem, stanowczo ani jednym słowem nie mówił ambasadorowi T. R. (w wypadku tym dokładne wymienianie imienia i nazwiska - zdaniem moim - potrzebne by nie było), ale że przed dwiema godzinami dotarła do mnie informacja rodem (to 'rodem' moje jest, nie pani 
Heleny Usijewicz) z wiarygodnego - a to bardzo - źródła, iż samo miasto Lwów Polakom Stalin prawdopodobnie oddałby (czy i inaczej jeszcze to samo wyrażając: właśnie Lwowa na rzecz Polaków zrzekłby się), gdyby na wszelkie inne nasze żądania w sprawie granic rząd londyński powiedzieć zechciał: 'Niech będzie tak', nareszcie". Rzecz to oczywista, że panu tę wiadomość przekazano w celu tym, by zaraz po powrocie $\mathrm{z}$ "Grand Hotelu" do ambasady pan pobiegł z nią - $\mathrm{z}$ tą właśnie wiadomością - do swego szefa, pana R. [...], więc też, rzecz jasna, byłaby ogromnie pani Helena Usijewicz na pana rozżalona (czy może nawet rozeźlona), gdyby poważnie potraktował jej prośbę o dyskrecję. A tak samo i wice wersa przecież również zdarzało się: pan prosił - też gorąco - panią Usijewicz, żeby to, co ma do powiedzenia wyłącznie jej, jakimikolwiek bądź (czy ściślej jeszcze mówiąc: żadnymi w ogóle) drogami nie przedostało się do wiadomości czy pana Mołotowa, czy - tym bardziej jeszcze - samego aż Stalina, a do powiedzenia ma pan jej to, że w sprawie granic z Londynu ambasador T. R. dostał czy rady, czy instrukcje aż nawet, świadczące, że w tej właśnie sprawie jest stanowisko polskie dokładnie takież, jakie było kilka tygodni temu albo - przeciwnie - owszem, zmianie uległo pewnej, jednak stanowczo nie aż takiej, jaka wprowadzić mogła Narkomindieł [tj. sowieckie MSZ] w stan czy euforii, czy zachwytu" (T. P a r n i c ki, Opowieść o trzech Metysach. T. 1: Raczej jednak oni. Warszawa 1992, s. 134-135).

Po zawarciu 30 VII 1941 układu Sikorski-Majski reaktywowano działalność Ambasady RP i umieszczono ją w przedwojennej jej siedzibie w Moskwie (ul. Spiridonowka 30). Po ewakuacji korpusu dyplomatycznego w połowie października 1941, związanej z przełamaniem przez wojska niemieckie frontu pod Smoleńskiem, Ambasada RP została przeniesiona do pałacyku z 1900 r. dr. Ericha Gustowicza Erna przy Czapajewskiej 165 w Kujbyszewie (Samarze).

21 Dmowszczycy - zwolennicy polityczni Romana Dmowskiego, endecy.

22 W kwietniu 1943, bezpośrednio przed likwidacją Ambasady RP w Kujbyszewie, Parnicki przedstawił ambasadorowi Tadeuszowi Romerowi memoriał o zasadach ułożenia po wojnie stosunków polsko-sowieckich. Ambasador wysłał memoriał ze swoją aprobatą do Londynu.

Drogi Janku,

Może ten list przyjdzie w sam dzień Twoich Imienin ${ }^{1}$ : pamiętasz te Imieniny sprzed dwu lat? Damaszek? Orient Palace Hotel, w którym ostatnio strzelano?... Życzę Ci wszystkiego, wszystkiego najlepszego, Mój Drogi - a sobie, bym kiedyś mógł jeszcze złożyć Ci życzenia osobiście...

Dawnoś do mnie nie pisał: nie jestem nawet pewien, czyś otrzymał mój bardzo długi list (polecony), gdziem wspominał o Gandhim i o starej Helenie [Usijewicz] i prosiłem, by Ludwik [Seidenman] napisał mi o swych wrażeniach ze Srebrnych Orłów... i o tym, żem bardzo już znużony... Dziś sytuacja jest dla mnie jeszcze jaśniejsza niż przedtem: choć trudno przekreślić (i realnie, i jeszcze bardziej jako symbole) i starą Helenę, i młodą Kirę ${ }^{2}$, przekreślam: jestem z naszym kujbyszewskim Stefanem [Gackim], nie z Ksawerym [Pruszyńskim] $]^{3}$ : choć pierwszego nie lubię, a drugiego - tak...

I przygotowany jestem psychicznie na wszystkie następstwa. Nawet na to, że nigdy już nie zobaczę swej żony - czyli nigdy już w ogóle pewnie nie będę miał żony, będąc żonatym... A podobno (pisała mi p. Hanka W[ierzyńska] ${ }^{4}$ ) żona Ludwika ${ }^{5}$ się odnalazła - cieszę się za niego szczerze: ale czy i on ją kiedy zobaczy? 
Wczoraj byłem $z$ Min[nistrem] Merdingerem u Prezydenta Meksyku ${ }^{6}$ - druga to ceremonia w moim życiu (pierwsza - na Kremlu, $z$ Romerem ${ }^{7}$ ) - może to jedna $z$ ostatnich moich funkcyj dyplomatycznych? A co będę robił potem? Nie wiem i nie troszczę się teraz o to: bylebym takie mógł mieć życie, aby mieć warunki zrealizowania celu swego przyjazdu do Meksyku - napisania powieści o Azteczce doñi Marinie. Ostatecznie można napisać powieść w każdych warunkach - byleby się nie umarło $\mathrm{z}$ głodu...

Kister narobił huku, ale w rezultacie - widze - z angielskiego \{wydania Srebrnych Orłów - nici... Czyżby to miała być moja ostatnia książka?! Aha, posłałem na Twój adres Ludwikowi 2-gi tom - ale on nic, nic nie pisze... I Pawliszak ${ }^{8}$ nie pisze: a ja wysłałem do niego przez te 10 miesięcy z 10 listów, a on - żadnego... $\}^{9}$

$\{$ Raz jeszcze życzę $\mathrm{Ci}$, Janku, wszystkiego najlepszego z okazji Dnia Imienin. Cóż Wasze urocze kobiety? Irena, Krysia, Marysia? „Co z oczu...”10 itd. No, ale trudno, trzeba przyzwyczaić się wreszcie być wiecznie samotnym i nie uważać cieni za rzecz uchwytną.... $\}^{11}$

\{Pani Marcie ręce całuję. Ludwika ściskam: niech do mnie napisze. Ściskam też Ciebie: gorąco, bardzo...

$$
\text { Teodor }\}^{12}
$$

Pożółkła karta papieru średniej grubości, o wymiarach $21 \times 27,5 \mathrm{~cm}$, zapisana obustronnie ciemnogranatowym atramentem; pismo równe; na szerokim lewym marginesie dopiski w układzie pionowym (karta recto: 6 linijek, karta verso: 5 linijek). Dodatkowo w lewym górnym rogu ukośny dopisek „do góry nogami” z podpisem nadawcy. W prawym górnym rogu notatka atramentem ręką Jana Erdmana: „Odpowiedziałem 14 VII 45".

1 Jan Erdman obchodził imieniny 24 VI, we wspomnienie Narodzin Jana Chrzciciela.

2 Mowa o Kirze Ko r c how ej. Do tej pory nie udało się niczego dowiedzieć na jej temat.

3 Pruszyński po ukonstytuowaniu się w czerwcu 1945 Tymczasowego Rządu Jedności Narodowej został z jego ramienia posłem nadzwyczajnym w Holandii.

4 Chodzi o Halinę Wierzyńska, z domu Pfeffer, primo voto Sztompkową (1903-1980), drugą żonę Kazimierza Wierzyńskiego. Parnicki nazywał ją Hanka.

5 Zofia (Ida Sophie) Seiden manowa, z domu Heller (zm. 1988) - żona adwokata Ludwika Seidenmana; do Stanów Zjednoczonych przyjechała z Polski w 1947 roku.

6 W tym czasie (w latach 1940-1946) prezydentem Meksyku był Manuel Ávila Camacho (1897-1955), członek Partii Rewolucyjno-Instytucjonalnej; 22 V 1942 wypowiedział wojnę państwom Osi.

7 Tadeusz Ro m er (1894-1978) - dyplomata; w latach 1935-1937 poseł RP w Lizbonie; w 1937-1941 ambasador RP w Tokio; 15 IX 1942 mianowany ambasadorem rządu RP w ZSSR, do Kujbyszewa przybył 12 X 1942. Pod koniec października udał się do Moskwy, aby złożyć listy uwierzytelniające na Kremlu. Towarzyszył mu Teodor Parnicki, który w tym czasie sprawował funkcję p.o. attaché prasowego. „Udało mi się przekonać ambasadora Romera, który jechał do Moskwy celem złożenia listów uwierzytelniających przewodniczącemu Rady Najwyższej ZSRR Kalininowi, żeby mnie też zabrał jako jednego z pięciu swoich towarzyszy, a to właśnie jako kogoś do załatwiania spraw prasowych. To też miało się w Moskwie załatwiać, ale myślę, że głównie skusiłem go tym, że Moskwa jest miastem mojego dzieciństwa, więc miałby we mnie osobistego i przewodnika, i komentatora. W każdym razie pojechałem z nim do Moskwy; mniejsza w tej chwili o szczegóły; jego rozmowy na szczycie były dość - nazwijmy to - burzliwe, sytuacja polityczna i historyczna była dość specjalna, natomiast na moim szczeblu szło wszystko wtedy wyjątkowo dobrze i przyjemnie, i składnie; i widocznie ambasadorowi jakieś moje przy nim działanie przez prawie dwa tygodnie w Moskwie podobało się, bo tuż przed wyjazdem zaszczycił mnie niesłychanie miłą propozycją - dowiodło to jego inteligencji i umiejętności przewidywania, bo właśnie prawdopodobnie i to też, między innymi, może wprawdzie nie rozstrzygnęło ostatecznie, ale pokaźnie dopomogło do stworzenia harmonii w dzia- 
łaniu między mną a Erdmanem. Mianowicie ambasador Romer powiedział mi: „Wie pan, ja wystąpię z wnioskiem do rządu londyńskiego i poproszę rząd radziecki o zgodę, żeby rozdzielić funkcje attaché prasowego i attaché kulturalnego. Wobec tego Erdman będzie miał wyłącznie sprawy prasowe, pan zaś będzie miał, też wyłącznie, sprawy kulturalne i tak samo jak on - pan automatycznie, w wyniku moich starań, dostanie też status dyplomatyczny, i pan nie będzie, jak było za Pruszyńskiego, zastępcą Erdmana, tylko będziecie panowie działali równolegle». I rzeczywiście działaliśmy równolegle. I [...] w wielkiej harmonii” (T. P a r n i c ki, Historia $w$ literaturę przekuwana. Warszawa 1980, s. 16-17).

8 Franciszek Paw li s zak (1906-1974), przed wojną związany był z radiem we Lwowie; po wybuchu wojny znalazł się w Stanach Zjednoczonych, współpracował m.in. z „Nowym Światem”; od drugiej połowy lat czterdziestych do 1965 r. jako Jan Gruda prowadził audycje w „Głosie Ameryki”; znajomy Parnickiego $\mathrm{z}$ okresu lwowskiego.

9 Dopisek wzdłuż lewego marginesu k. $1 \mathrm{v}$.

10 „Co z oczu, to z serca” - przysłowie polskie. Zob. S. Ad a lb erg, Oko. W: Księga przysłów, przypowieści i wyrażeń przysłowiowych polskich. Warszawa 1889-1894, s. 356.

11 Dopisek wzdłuż lewego marginesu k. 1r.

12 Dopisek w lewym górnym rogu k. $1 \mathrm{r}$.

$\left\{\right.$ T. Parnicki\} ${ }^{1}$

\{POSELSTWO

RZECZYPOSPOLITEJ POLSKIEJ

W MEKSYKU

LEGACION DE POLONIA

EN MEXICO $\}^{2}$

Paseo de la Reforma 237 - 2

México D. F.

México

\section{Written in Polish}

\{Meksyk, dn.\} 13 lipca\{194\}5

\{México, D. F.

Calle Mérida, 121$\}^{3}$

Drogi Janku,

Znowu nic nie piszesz, a przecież chciałbym wiedzieć, co się dzieje z Tobą i P. Marta, z Ludwikiem [Seidenmanem], z Pawliszakiem... Napisz koniecznie jak najprędzej. Czy Kister wrócił z Angliii do N[ew] Yorku? Gdy wróci, przypomnij mu, bądź łaskaw, jego obietnicę dla mnie - właśnie teraz to aktualne - on musi wiedzieć, o co chodzi... o zaliczkę...

A co ze mną? Dostanę 3-miesięczną odprawę - około 700 dolarów - z tego 2/5 wypłacę na długi - chcę być czysty z długami... Za resztę spróbuję żyć przez 6 miesięcy i przez ten czas napisać 2-gą część Aecjusza ${ }^{5}$ - może też Mojżesza i Helenę ${ }^{6}$, a może i jaką powieść współczesną... A co potem? - nie wiem - może już koniec, ale \{jeśli koniec, to niechże po mnie coś pozostanie...

\section{Ściskam Cię: Teodor $\}^{7}$}

Pożółkła karta papieru średniej grubości, o wymiarach $21 \times 27,5 \mathrm{~cm}, \mathrm{z}$ oficjalnym nadrukiem Poselstwa RP, zapisana obustronnie ciemnogranatowym atramentem; pismo bardzo rozstrzelone, litery bardzo duże, równe; szeroki margines lewy na karcie recto (niezapisany), niewielki dopisek pionowy na wąskim marginesie prawym karty verso.

1 Dopisek odręczny Parnickiego nad przekreślonym przezeń nadrukiem. 
W klamry ujęto nadruk listownika Poselstwa RP (przekreślony przez Parnickiego). Pod nim adres prywatny pisarza.

3 W klamrach umieszczone zostały elementy nadruku listownika Poselstwa RP, przekreślonego ręką Parnickiego.

4 Wiosną 1945 Marian Kister udał się drogą morską do Londynu (8 V, w Europie dzień zakończenia drugiej wojny, zastał go na statku). W Londynie przede wszystkim starał się zorientować w możliwościach rozprowadzenia części nakładów wydanych przez siebie książek pośród Polaków znajdujących się w Wielkiej Brytanii.

5 Drugą część Aecjusza, ostatniego Rzymianina Parnicki napisał dopiero w połowie lat sześćdziesiątych, ale planował ja jeszcze przed wojną, o czym świadczy jego korespondencja z Symonolewiczem (część ta miała nosić tytuł Największa gra): „W drugiej powieści Aecjusz już będzie raczej dziejowym tłem niż "subiektem": bezpośrednio zetknie się z nim czytelnik 2 czy 3 razy, ale za to tym silniej powinno uwypuklać się jego historyczne znaczenie i wielkość, jako że niewidzialny ciążyć będzie nad wszystkim, co się w powieści będzie działo... Ze "znajomych" $z$ pierwszej powieści wysuną się na czoło Merobaudes, Awitus, król Teodoryk wizygocki i wie Pan, kto jeszcze?... Oto possesor Karyzjusz (jedna z głównych postaci w Największej grze). $Z$ wybitnych postaci historycznych, które dotąd nie występowały w Aecjuszu, obecnie wystapią herezjarcha Eutyches, poeta Sydoniusz Apollinaris, Meroweusz frankoński, córka Placydii - Honoria, Torysmund i Teodoryk II wizygoccy i w jednym krótkim epizodzie: sam Atylla. Powieśc skonstruowana ma być w ten sposób, że stanowić będzie zupełnie samodzielną całość: czytać ją można będzie, nie znając wcale Aecjusza" (list z 13 VII 1936). W tym czasie Parnicki myślał nawet o napisaniu kolejnych tomów: „A tak wyraźnie widzę przed sobą drogę twórczą, którą winienem iść w ciągu najbliższych 3 lat... Tetralogia $z \mathrm{~V}$ wieku (część I: Aecjusz; II: Największa gra; III: okres między śmiercią Aecjusza a śmiercią Walentyniana; IV: dramat cesarza Awitusa [...])" (list do Symonolewicza, z 5 VIII 1936). T. Parnicki w Postscriptum do Śmierci Aecjusza (Warszawa 1966, s. 428) napisał: „Praca nad [tal powieścią [...] - choć planowana od wielu lat w Meksyku - dokonywała się w całości w Warszawie, a ukończona została dokładnie w trzydzieści lat i w trzy dni bez jedenastu godzin po ukończeniu przeze mnie we Lwowie pracy nad powieścią Aecjusz, ostatni Rzymianin. Mianowicie: prace nad Aecjuszem, ostatnim Rzymianinem ukończyłem w niedzielę 8 marca 1936 roku około godziny 11 rano; pracę nad Śmiercia Aecjusza - w piątek 11 marca 1966 roku o godzinie 0:28”.

$6 \quad$ Parnicki nie napisał powieści o Mojżeszu i Helenie, ale zarys jej fabuły przedstawił w części drugiej Nowej baśni, ukończonej w 1962 roku. Jeden z jej bohaterów, biskup Burgos Alfons de Santa Maria, w rzeczywistej lub tylko wyimaginowanej rozmowie z podległym jego inkwizytorskiej władzy Iwenem, „chlubą i ozdobą [...] ongiś studium gramatyki u franciszkanów w Kantabrydze angielskiej”, skłania go do rozwinięcia pomysłu tragedii o Hermionie, córce Heleny trojańskiej i Menelaosa, która wraz z nimi po powrocie z Troi znalazła się w Egipcie. Kochając Orestesa, nie godzi się ona z decyzją rodziców, by poślubiła Pyrrusa, i uczestniczy w eksodusie Żydów pod wodzą Mojżesza. Na wybrzeżu filistyńskim spotyka Orestesa, który schronił się tam już po zabiciu matki. Ścigani przez Helenę i Pyrrusa, młodzi uciekają na zachód, zamieszkały przez Atlantów. I tam ponosza śmierć, złożeni w ofierze bogom, żywiącym się krwią ludzi. Mojżesz w tej tragedii „Mędrcem był [...] mogącym bratać się i z najwyższymi Egiptu arcykapłanami - wyznającymi wiarę tajemną, iż żadnych bogów nie ma poza Jednym Jedynym, mającym słońce za maskę świetlistą na obliczu swym nieodgadnionym - lecz także z maluczkimi. I z dwu tych samych możliwości stworzył jedną, nową, a wyższego rzędu: umiał porwać maluczkich do buntu, czyli [...] do secesji, lecz zarazem moc chcąc ducha im dać taką, by się nie bali bojowych wozów wielmożów, wiarę im w Boga Jedynego objawił, łaskę też równocześnie szczególną owego Jedynego obiecując, co istotnie z takim maluczcy przyjęli zapałem, że nieustraszenie przedarli się poprzez liczne wozów bojowych szeregi ku morzu..." (T. Pa rn i c ki, Nowa baśń. Cz. 2: Czas siania i czas zbierania. Warszawa 1963, s. 333, 340-341). Dopisek wzdłuż prawego marginesu k. lv. 


\section{Drogi Janku,}

Serdecznie dziękuję Ci za list, choć króciutki, ale bardzo treściwy. Koniecznie daj znać o narodzeniu się syna lub córki naty chmiast. O sobie teraz nie piszę wiesz chyba sporo o mnie od Ludwika [Seidenmana], do któregom ostatnio wiele pisał. Nie myślę, nie chcę myśleć o niczym, tylko o twórczości - zobaczymy, czy tę grę rozegram szczęśliwie, czy też jak u Giermanna w Pikowej Damie moja karta będzie bita ${ }^{1} .$. Materialnie na razie liczę trochę na Kistera - nie jestem pewien, czy mi pomoże; jeśli nie - chyba zrobi głupstwo...

Dostaję dokumenty uchodźcy politycznego w Meksyku - Droh[ojowski] ${ }^{2}$ będzie dla mnie „pustym miejscem” - bardziej skomplikowana sprawa z Natalia [Aszkenazy-Drohojowską...3

Miałem chwilę, jedną chwilę wahania: wiesz, że mam idée fixe na punkcie powrotu wschodniego chrześcijaństwa na łono Kościoła rzymskiego \{i ambicje udziału w tworzeniu procesu dziejowego owego powrotu... $\}^{4}$ - więc gdy rozeszła się pogłoska, że profesor [Kot] jedzie do Watykanu (co się nie potwierdziło ${ }^{5}$ - przeciwnie, Oni zerwali konkordat!! 6 ), miałem parę bezsennych nocy...

Ale to już dziś jest za mną. Jeśli mam noce bezsenne, to chyba z powodu, iżem bardzo, bardzo samotny, no i z racji nowych planów twórczych...

Ręce Pani Marty z oddaniem najszczerszym całuję, Ciebie ściskam bardzo goraco -

Teodor

Pożółkła karta papieru średniej grubości, o wymiarach $21 \times 27,5 \mathrm{~cm}$, zapisana obustronnie niebieskim atramentem, pismo równe, średniej wielkości, lekko pochylone; dość szeroki lewy margines. Na lewym marginesie karty recto niewielki dopisek ukośny, zaznaczony strzałką.

1 Nawiazanie do opowiadania Dama pikowa A. P u s z k i n a (1833). Jego bohater, Hermann, pragnie wykorzystać tajemnicę sukcesu w grze w karty zdradzoną mu przez hrabinę Annę Fiedotownę. Ryzykując, traci cały majątek i kończy swe życie w domu dla obłąkanych.

2 Jan Drohojowski (1901-1979) - dyplomata, ukończył École Libre des Sciences Politiques w Paryżu; w latach 1922-1923 attaché Poselstwa RP w Hadze, w 1923-1926 pierwszy sekretarz Poselstwa RP w Rzymie; po zamachu majowym odszedł z dyplomacji; w latach 1926-1930 przebywał w Stanach Zjednoczonych; w latach 1930-1931 korespondent „Kuriera Poznańskiego” w Berlinie; w 1931 r. nawiązał kontakt z Frontem Morges i gen. Władysławem Sikorskim; po wybuchu drugiej wojny światowej wrócił do służby dyplomatycznej, w latach 1939-1942 pełnił funkcję radcy Ambasady RP w Waszyngtonie, w 1942 r. chargé d'affaires Poselstwa w Hawanie, przedstawiciela Polski przy rządzie Czang Kaj-szeka w Chinach, w 1943 r. konsula generalnego w Jerozolimie; w latach 1943-1944 był wiceministrem informacji i dokumentacji w rządach gen. Sikorskiego i Stanisława Mikołajczyka; w drugiej połowie $1945 \mathrm{r}$. objął funkcję posła w Meksyku z ramienia Tymczasowego Rządu Jedności Narodowej w Warszawie (po ucieczce Mikołajczyka w 1947 r. pozostał w służbie dyplomatycznej Polski komunistycznej); w latach 1951-1952 był posłem w Kairze; w 1953 r. aresztowany za próbę nielegalnego przekroczenia granicy; po wyjściu z więzienia w r. 1955 poświęcił się pracy pisarskiej. Opublikował Jana Drohojowskiego wspomnienia dyplomatyczne (Warszawa 1959).

3 Natalia Drohojowska, $z$ domu As zkenazy, secundo voto Fran co - attaché Ambasady RP w Moskwie-Kujbyszewie; do ZSSR przyjechała z Waszyngtonu na przełomie 1941 i 1942 r.; pracowała w referacie politycznym; w ostatnich miesiącach istnienia Ambasady redagowała biuletyn $\mathrm{w}$ języku angielskim z przeznaczeniem dla innych placówek dyplomatycznych; ZSSR opuściła 
w ostatniej grupie personelu Ambasady; 20 XI 1943 wzięła ślub z Janem Drohojowskim; w r. 1951 towarzyszyła mężowi na placówce w Kairze; po jego odwołaniu w 1952 r. i wezwaniu do Polski osiedliła się we Francji.

4 Dopisek na lewym marginesie k. lr.

5 Profesor Stanisław Kot po wejściu w czerwcu 1945 Stanisława Mikołajczyka do Tymczasowego Rządu Jedności Narodowej wrócił do Polski, skąd wysłano go jako ambasadora do Rzymu. Po zerwaniu z rządem w Warszawie w 1947 r. pozostał na emigracji.

612 IX 1945 Tymczasowy Rząd Jedności Narodowej ogłosił unieważnienie konkordatu zawartego między II RP a Watykanem. Pretekstem unieważnienia konkordatu stało się m.in. powierzenie w grudniu 1939 przez Stolicę Apostolską administracji nad diecezją chełmińską Niemcowi, biskupowi gdańskiemu Karolowi Splettowi.

México D. F. - 22/XII [19]45 Paseo de la Reforma 237/2

Drogi Janku,

Zasyłam Pani Marcie i Tobie najserdeczniejsze życzenia Wigilijne i Noworoczne oraz życzenia w związku z mającym niebawem nastąpić zwiększeniem się rodziny.

Dawno nie miałem ani od Ciebie, ani o Tobie żadnych wiadomości; czyś nie dostał mojego listu, wysłanego na ten - co i teraz wysyłam - adres? Chciałbym wiedzieć, jak wam z P. Marta się powodzi - czy macie jakie plany co do odmiany biegu swego życia, czy też zamierzacie na dłużej pozostać na farmie ${ }^{1}$. U mnie rewelacyjnych zmian na razie nie ma. Miałem od Kistera i od Arleta (od tego ostatniego z[a?] pośrednictwem p. Dobrowolskiej ${ }^{2}$ ) pewne propozycje odnośnie [do] przeniesienia się do Stanów - ale po krótkim namyśle ustosunkowałem się do tych propozycyj definitywnie odmownie...

Czas swój spędzam obecnie głównie - a właściwie prawie wyłącznie - na pisaniu powieści $z$ dziejów Stan[ów] Zjedn[oczonych] ${ }^{3} \ldots$ Oczywiście, raczej mam tremę wydaje mi się, że stworzę rzecz poronioną i skompromituję się - chwilami myślę, że tak dalecy od nas ludzie w[ieków] V czy X są mi znacznie bliżsi i zrozumialsi niż Kentukijczycy, Bostończycy czy Nowoorleńczycy pocz[ątku] XIX wieku... Wbrew sugestiom Ludwika [Seidenmana], powieść nie będzie miała happy endu - wydaje mi się (na podstawie filmów i rozmów z ludźmi dobrze znającymi współczesnych Amerykanów), że publiczność czytająca Stanów dojrzała już do właściwej oceny tragizmu... Zresztą, powieść moja - tak jak została zawiązana (ostry konflikt ideologiczny między parą szalenie zakochanych w sobie osób, dojrzałych politycznie ponad przeciętny poziom swej epoki) - nie może mieć happy endu w potocznym znaczeniu tego określenia...

Wiesz już zapewne, że Kister wydaje 2-gie (polskie) wydanie Aecjusza. Zrazu ukrywał ode mnie (wiem to od Kuncewiczowej ${ }^{4}$ ), że z góry dostał z Anglii zamówienie na 2250 egz[emplarzy]. Ale gdy zobaczył, że wiem o tym - przyznał sie - nawet kapie mi po trochę pieniądze i jakoś żyję... Ciężko mi, ale każdy musi żyć tak, jak chce \{i ponosić konsekwencje swej postawy wobec życia... ${ }^{5}$

Najważniejsza dla mnie rzecz to zachować dawne mieszkanie - około 50 dol[arów] - wielu rzeczy muszę sobie odmawiać, żeby co miesiąca mieć na czynsz... A w innym mieszkaniu chyba nie mógłbym pracować. Szczerze powiem, że ocze- 
kuję od Marty recenzji z Aecjusza po ukazaniu się 2-go wydania - przecież tyle jest pism polsko-amer[ykańskich], gdzie by taką recenzję można było umieścić. Wydaje mi się czasem, że i na dobrą, \{wnikliwą ${ }^{6}$ recenzję Sr[ebrnych] Orłów znalazłoby się miejsce... Przyznam się, że ciężko mi przychodzi znoszenie faktu dość anormalnego, jak to, że jedna $z$ b[ardzo] nielicznych powieści polsk[ich] czasu wojny ${ }^{7}$ nie doczekała się żadnej recenzji... Miałem natomiast w sprawie Sr[ebrnych] Orłów list od ks. Meysztowicza ${ }^{8}$ z naszej Ambasady przy Watykanie - poza tym historyka Kościoła... Niepokoi go mocno wpływ „freudyzmu” na moją twórczość, ale winszuje mi przezwyciężenia tradycji szkoły krakowskiej ${ }^{9}$, która ulegając doktrynie o ciągłości postępu - przeciwstawiała dorobek kulturalny Polski końca XIV w[ieku] barbarzyńskiej i prymitywnej rzekomo atmosferze czasów Bolesławowskich... Wedle głębokich ostatnimi laty badań ks. Meyszt[owicza] w Bibl[iotece] Wat[kańskiej] wizja Chrobrego i otoczenia jego - ich poziomu polit[ycznego] i kult[uralnego] etc. - w Sr[ebrnych] Orła[ch] bliższa jest prawdy hist[orycznej] od ujęć Szujskiego ${ }^{10}$ czy Bobrzyńskiego ${ }^{11} \ldots$

Czy Ludwik nie jest chory? Dawno do mnie nie pisze, a wyczekuje od niego odpowiedzi w kilku b[ardzo] ważnych dla mnie sprawach... Czy adres Pawliszaka naprawdę jest 114 East 72 ulica? I czy nie znasz adresu p. Ireny, byłej Prażmowskiej? Dostałem od niej zawiadomienie o ślubie, ale bez adresu - nie mogłem więc złożyć powinszowań... Pisałem też do Marysi S. na 1142, Madison Ave[nue] - ale nie dostałem odpowiedzi... Krysia też nic nie pisze... Z Londynu pisują do mnie Kozioł i Weintraub ${ }^{12}$, \{rzadko p. Kossowska\} ${ }^{13}$. Od p. Hanki W[ierzyńskiej] wiem, że Zawadowski ${ }^{14}$ zdazżył szereg osób z Teheranu - m.in. Danusię Grab[owska] ${ }^{15}$ przerzucić do Syrii. Mnie osobiście niepokoi brak cienia wiadomości o mojej żonie. Czasami korci mię, żeby zwrócić się w tej sprawie do starej Heleny U[sijewicz] (T. Romer ${ }^{16}$ prosił Mniszka ${ }^{17}$, żeby szukał mojej żony) - ale odrzucam od siebie tę pokusę... Proces dziejowy wykopał między mną a Heleną U[sijewicz] przepaść zaiste głębszą i szerszą niż Atlantyk. Ale szerszą niż Atlantyk okazuje się też być ulica Paseo de la Reforma - Natalia [Aszkenazy-Drohojowska] mieszka w hotelu po drugiej stronie ulicy, a dalej mi do niej, niż gdy była w Londynie... Oczywiście, jeśli zechce ze mną się spotkać na gruncie neutralnym - spotkam się z nią b[ardzo] chętnie. Ale jej się nie śpieszy. Czyżby czekała, że ja się zgłoszę? Nie mogę. Powinna to zrozumieć. M.in. i to, że właśnie jako przysięgły rusofil nie mogę aprobować w Polsce takiej sytuacji, która tylko pogłębia nienawiść między Polakami a Rosjanami. A są też rzeczy, których ona nie zrozumie. M.in. to, że ciażzy na mnie, silniejszy może niż na kim innym, obowiązek w i e r n o ś c i, a to ze względu na ratowanie honoru krwi, co płynęła w żyłach mojej matki ${ }^{18}$ - bo na ogół ludzie tej krwi nie mają wiele zrozumienia dla elementu wi erności. Niestety, to fakt, i nie \{można zaprzeczać jego istnienia, choćby i znalazło się takie czy owo usprawiedliwienie... ${ }^{19}$

\{Przed tygodniem byłem 2 dni nad Pacyfikiem (zabrali mnie swym autem pp. Stebelscy ${ }^{20}$ ). Gdybym więc przebył ocean, miałbym już za sobą całą kulę ziemską okrążona - bom wszak wyrostkiem (1919-1920) patrzył na tenże Pacyfik od strony Władywostoku $\left.{ }^{21}\right\}^{22}$

\{Proszę Cię, Janku, gorąco - pisz do mnie. Ściskam Cię bardzo serdecznie. Pani Marcie ręce całuję - 
Dwie pożółkłe karty bardzo cienkiego papieru bibułowego, o wymiarach $21 \times 28 \mathrm{~cm}$, zapisane obustronnie ciemnogranatowym atramentem. Pismo równe, dość gęste. Dopiski pionowe na marginesie lewym karty 1 verso oraz karty 2 recto i verso. Niewielki dopisek poziomy u dołu karty 1 recto na lewym marginesie. W lewym górnym rogu karty 1 recto dopisek ołówkiem Jana Erdmana: „Odpowiedziałem 29 XII 45”.

1 Marta i Jan Erdmanowie w 1945 r. kupili kurzą fermę pod Lakewood w stanie New Jersey. Prowadzili ją do 1950 roku. Marta w liście z początku 1946 r. pisała do rodziców, już po narodzinach pierwszej córki, Anny: „Po ośmiu dniach wróciłam do domu, bo czas był ciężki i trzeba było oczyścić kurniki na przyjęcie dziewięciuset jednodniowych kurcząt, i Jan pracował dniem i noca jak wariat, nieraz zupełnie bez snu" (cyt. za: M. W a ń k o w i c z, Ziele na kraterze. Wyd. 10. Warszawa 1976, s. 406).

2 Anna Dobrow olska - żona majora Stefana Dobrowolskiego, attaché wojskowego w Poselstwie RP w Meksyku; absolwentka filologii klasycznej na Uniwersytecie Stefana Batorego w Wilnie; po zakończeniu w lipcu 1945 misji Poselstwa pracowała - z ramienia Kongresu Polonii Amerykańskiej - przy likwidacji obozu polskich uchodźców w Santa Rosa.

3 Powieść z historii Stanów Zjednoczonych zaczął Parnicki pisać 17 XI 1945. Jej akcja miała się toczyć w Nowym Orleanie po przyłączeniu w 1803 r. Luizjany do USA, ze szczególnym wyeksponowaniem wydarzeń z okresu wojny amerykańsko-brytyjskiej (1812-1815). Głównymi bohaterami utworu autor chciał uczynić parę małżonków: nieprzejednanie antybrytyjską republikankę z Nowego Orleanu i probrytyjskiego federalistę z Bostonu. Planował też wprowadzenie postaci mieszańca polsko-holenderskiego. Zasadniczą opowieść amerykańską z początków XIX w. zamierzał obudować prologiem i epilogiem, nawiązującymi do wydarzeń współczesnych ze znanych mu Rosji, Bliskiego Wschodu i Anglii, lecz bez wtrętów autobiograficznych. W trakcie pisania próbował dotrzeć do wielu opracowań, takich jak np. E. Ri pl ey, The Social Life in Old New Orleans czy J. A. Ro be rts o n, Luisiana under Spain, France and United States. W lutym 1946 miał już 400500 stronic maszynopisu (około jedną trzecią całości). Ostatecznie jednak powieści nie ukończył. Maria Kuncewiczowa w 1940 r. wznowiła działalność polskiego PEN Clubu na emigracji (stała na jego czele do 1945 r., do czasu cofnięcia mu uznania ze strony Międzynarodowego PEN i jego przekształcenia się w Związek Pisarzy Polskich na Obczyźnie).

Dopisek na lewym marginesie k. $1 \mathrm{r}$.

Dopisek nad główną linią tekstu.

W rękopisie: „wojna”.

8 Ks. Walerian Meysztowicz (1893-1982) - przed wojna wykładał na Wydziale Teologicznym Uniwersytetu Stefana Batorego; w latach 1932-1937 oraz podczas drugiej wojny światowej pełnił funkcję radcy w zakresie prawa kanonicznego w Ambasadzie RP przy Stolicy Apostolskiej; w r. 1945 utworzył w Rzymie Polski Instytut Historyczny; w 1954 r. zainicjował wydawnictwo „Sacrum Poloniae Millennium” i rocznik „Antemurale”; w 1960 r. rozpoczął wydawanie nowej serii publikującej źródła do historii Polski „Elementa ad Fontium Editiones”; autor wspomnień Poszło $z$ dymem (1973) i To, co trwate (1974).

9 Krakowska szkoła historyczna - kierunek historiografii polskiej, zainicjowany dziełem W. Ka li nki Galicja i Kraków pod panowaniem austriackim (1853). Szkoła prezentowała krytyczną wizję dziejów polskich, według której to anarchiczny charakter narodowy, wadliwy ustrój polityczny i upośledzenie warstw nieszlacheckich przyczyniły się do upadku I Rzeczpospolitej. Występowała w opozycji do historiografii romantycznej, zwłaszcza przeciw demokratyzmowi Joachima Lelewela. Należeli do niej m.in. Józef Szujski, Stanisław Koźmian, Stanisław Tarnowski, Michał Bobrzyński, Stanisław Smolka.

10 Józef Szujski (1835-1883) - historyk, publicysta, dramaturg, polityk; początkowo szlachecki demokrata, po upadku powstania styczniowego stał się czołowym ideologiem konserwatystów galicyjskich, zwanych później stańczykami; współautor „Teki Stańczyka” na łamach „Przeglądu Polskiego", czyli zestawu pamfletów na przeciwników politycznych z obozu demokratycznego; przyjmował prowidencjalizm, a więc pogląd, według którego w historię wpisany jest Boży plan, sprawiając, że zmierza ona do powrotu do stanu sprzed upadku człowieka; autor zarysów: Dzieje Polski (t. 1-4. 1862-1866) i Historia Polski (1880), oraz dramatów historycznych: Halszka z Ostroga (1859), Królowa Jadwiga (1860).

11 Michał B obrzyń s ki (1849-1935) - polski historyk i polityk konserwatywny; należał do drugiej 
generacji reprezentantów krakowskiej szkoły historycznej; autor Dziejów Polski w zarysie (1877), Szkiców i studiów historycznych (t. 1-2. 1922).

12 Wiktor Weintraub (1908-1988), historyk literatury; w latach trzydziestych uprawiał krytykę literacką na łamach „Wiadomości Literackich”; w październiku 1939 znalazł się we Lwowie; w latach 1941-1942 pracował w biurze prasowym Ambasady RP w Moskwie-Kujbyszewie; od 1943 do $1945 \mathrm{r}$. w Palestynie redagował dwutygodnik „W Drodze”; w latach 1945-1950 mieszkał w Londynie; w latach 1948-1950 redagował „Teki Historyczne”, kwartalnik Polskiego Towarzystwa Historycznego w Wielkiej Brytanii; od 1950 r. był profesorem slawistyki w Harvard University. Zachowały się listy Parnickiego do niego z lat 1944-1988 (Bibl. Jagiellońska, Oddział Rękopisów, zespół archiwalny Anny i Wiktora Weintraubów).

Dopisek na lewym marginesie k. 2v.

14 Zygmunt Zaw a d o w s ki (1899-1978) - dyplomata, w latach 1930-1933 wicekonsul RP w Kijowie; później kierownik działu niemieckiego w referacie politycznym Ministerstwa Spraw Zagranicznych; w latach 1940-1942 radca Poselstwa RP w Madrycie, w 1942 r. w Lizbonie, od 27 XII 1942 do maja 1943 radca i chargé d'affaires Ambasady RP w Moskwie-Kujbyszewie; od października 1943 kierownik Konsulatu RP w Bejrucie, w latach 1944-1956 poseł RP w Libanie i jednocześnie (1944-1946) w Syrii; następnie pełnił funkcję nieoficjalnego przedstawiciela władz londyńskich w Bejrucie; Liban opuścił w 1971 r.; w latach 1976-1978 minister spraw zagranicznych w rządzie Kazimierza Sabbata; autor recenzji paryskiego wydania Końca „Zgody Narodów”, zatytułowanej Tajemnica Teodora („Wiadomości” 1956, nr 43).

15 Na liście pracowników Ambasady RP w Moskwie-Kujbyszewie znajduje się Danuta Grabowska, ale żadnych innych danych na jej temat nie udało się ustalić.

16 Tadeusz Romer w latach 1943-1944 był ministrem spraw zagranicznych w rządzie Mikołajczyka; od 1945 r. przebywał na emigracji, najpierw w Wielkiej Brytanii, później w Kanadzie; w latach 1948-1954 wykładał na McGill University w Montrealu; od 1950 r. przewodniczył Komisji Skarbu Narodowego w Kanadzie; przed ewakuacją Ambasady na Bliski Wschód przekazał rządowi RP w Londynie pro memoria w sprawie zasad ułożenia polsko-sowieckich stosunków po wojnie, którego rzeczywistym autorem był Parnicki.

17 Aleksander Mnis zek (1904-1972) - urzędnik Ministerstwa Spraw Zagranicznych; w latach 1939-1940 szef sekretariatu premiera gen. Sikorskiego; od 1 IX 1941 do 26 IV 1942 radca prawny Ambasady RP w Moskwie-Kujbyszewie; szef referatu protokolarnego.

18 Matka pisarza, Augustyna Parnicka, z domu Piekars ka (ur. w 1881 w Kijowie, zm. w 1918 w Ufie), studiowała w Genewie; w 1904 r. w Berlinie wyszła za Bronisława (Brunona) Parnickiego; w 1913 r. wrócili razem do Rosji; do wybuchu pierwszej wojny światowej mieszkali w Moskwie; po rozpoczęciu działań wojennych, w r. 1915, jako poddani cesarza niemieckiego Wilhelma II musieli opuścić stolicę Rosji; osiedlili się w Ufie. Żydowskie pochodzenie matki stało się trwałym kompleksem Parnickiego, mającym wpływ na ukształtowanie się koncepcji bohatera jego powieści jako „mieszańca”. Pisał o tym w liście z 4 XII 1951 do J. Giedroycia, wspominając swój pobyt, w wieku 11 lat, w korpusie kadetów:

„[...] do tego swego nowego środowiska w żadnym sensie nie pasowałem, ale torturą życia stało się dla mnie dopiero wówczas, gdym na pytania moich kolegów, czy oboje moi rodzice byli Polakami-katolikami, odpowiadał, najpierw ze swobodną prostota, potem z histeryczną zaciętością "męczennika", którego moralnym obowiązkiem jest - mimo wszystko - dawać świadectwo prawdzie: „Nie, była Żydówką".

Wówczas to dowiedziałem się, że stokroć lepiej być ślepym lub garbatym niż pół-Żydem; wówczas też otrzymałem szereg sugestii, bym się powiesił - i zaczęło się we mnie rozwijać silne poczucie winy, że brak mi odwagi, by dokonać tego "logicznego a aktu samozniszczenia. To był [...] początek; dalsza historia tego "problemu" (czy, wedle Pana, "kompleksu") mogłaby wypełnić 3-4 tomy. Najznamienniejsze $\mathrm{w}$ tej historii na przestrzeni $30 \mathrm{z}$ górą lat to chyba moja własna postawa: postawa nie protestu, ale przyznawania racji tezie, że "mieszańcowi trzeba patrzeć na ręce...." (J. Gi edroyc, T. Parnicki, Listy 1946-1968. Cz. 1. Oprac., wstęp, przypisy A. Dobrowolski. Warszawa 2014, s. 62-63).

19 Dopisek wzdłuż lewego marginesu k. 2v.

20 Henryk St e b e ls k i (1904-1978) - dyplomata, przed wojną radca handlowy Ambasady RP w Paryżu; od sierpnia 1942 do maja 1943 wicekonsul RP w Bombaju; opiekował się polskimi uchodź- 
cami z Rosji w podróży z Indii do Meksyku (podróż morska z Bombaju do Kalifornii i kolejowa z Kalifornii do Meksyku trwała od 17 maja do końca czerwca 1943) i był pierwszym kierownikiem obozu uchodźców w Santa Rosa; w latach 1943-1945 sekretarz Poselstwa RP w Meksyku; po wojnie prowadził firmę farmaceutyczną. Parnicki był zaprzyjaźniony z Henrykiem i Elżbietą, „Betką" (1911-1994), z domu Orłowska, Stebelskimi. 12 VI 1965 podarował im egzemplarz dopiero co wydanej powieści I u możnych dziwny (1965) z odręczną dedykacją: „Drogim Betce i Henrykowi Stebelskim z wyrazami niezmiennej (a liczącej już sobie ponad 20 lat) przyjaźni oraz - przy sposobności szczęśliwego i przyjemnego zbiegu dat - także i z Najserdeczniejszymi powinszowaniami z okazji 25-lecia Ich małżeństwa, i z uściskami ofiarowuje Autor".

21 W latach 1919-1920 Parnicki przebywał w Pierwszym Kadeckim Korpusie Syberyjskim imienia cesarza Aleksandra I, stacjonującym pierwotnie w Pietropawłowsku, ale w związku z zawieruchą rewolucyjna przeniesionym do Omska, następnie na Daleki Wschód, do Władywostoku, a w końcu na Russkij Ostrow na Pacyfiku. W liście z 11 VII 1930 do Symonolewicza, pisząc o źródłach swojego romantycznego usposobienia, T. P a r n i c ki wspomina m.in. sposób spędzania czasu w trakcie pobytu na tej wyspie: „Na łonie przyrody, w obliczu oceanu, gdzie długie wakacje, które miały w Kadeckim Korpusie miejsce dzięki różnym przewrotom i niepokojom, wolałem spędzać z dala od kolegów, sam, wyobrażając siebie to krzyżowcem, to argonautą, to wędrującym Gotem czy Frankiem - lub też konkwistadorem" .

22 Dopisek wzdłuż lewego marginesu k. lr.

23 Dopisek wzdłuż lewego marginesu k. 2r.

Drogi Janku,

Najgoręcej winszuję Pani Marcie i Tobie - aby ta wasza córka ${ }^{1}$ wyszła na wspaniałą kobietę i wspaniałego człowieka ${ }^{2} .$. Wierzę, że tak się stanie... Cieszę się - nawiasem mówiąc - że to właśnie córka - zwykle życzę w duchu swym przyjaciołom, by przede wszystkim mieli córkę, ale nie zawsze życzenie to wyrażam głośno, niepewny, czy sprawi im to przyjemność. Ale przykład Antygony ${ }^{3}$ i Kordeliii ${ }^{4}$ - córki Tomasza More ${ }^{5}$ i Fenimore'a Coopera ${ }^{6}$ - od wczesnej młodości wbił mi mocno w głowę ideał: miłość córki to największa osłoda życia wybitnego człowieka. A Ty jesteś wybitny. Bardzo. Wierz mi. Przyjdzie czas - przyznasz mi rację. Już i teraz - Twój krok: pójście na farmę - świadczy tylko o b[ardzo] wybitnej nieprzeciętności człowieka, który powziął taką decyzję. Podziwiam Ciebie i P. Martę z powodu tej decyzji nadzwyczajnie. Choć, co prawda, trochę tak, jak Petroniusz podziwiał decyzję Winicjusza przejścia na chrześcijaństwo - podziwiając, nie szedł w ślady podziwianego, bo „Przyjaciele, nóg nie mam”7. Ja, Janku, mam w sobie akurat tyle aryjskości, by nie mieć żadnego ani talentu, ani zamiłowania do „interesów” - ale tego jest za mało, bym mógł pójść „na ziemię”... Zresztą, ja w ogóle n i gdzi e już nie chcę (ani na to „nóg nie mam”) pójść, poza swą pracą literacką. Polityka? Kiedyś wydawało mi się, że mam pociag - a może i talenty - w tym kierunku - ale przestało mi się wydawać, może dlatego, że jak na polityka, za mało mam w sobie fanatyzmu i za mało też cynizmu... Politykiem nie może być analityk. Zresztą, może pewnym swym koncepcjom politycznym potrafię dawać wyraz w powieściopisarstwie. Już mi się nawet wymarzył tytuł Powrót Światowida - o Polsce dzisiejszej, a raczej o całym procesie, który tę Polskę dzisiejszą przygotowywał - procesie, który Ty i ja - w pewnych przełomowych jego momentach - mogliśmy obserwować $\mathrm{z}$ bardzo bliska... ${ }^{8}$ 
Twoje ujęcie sprawy mego przyjazdu do Stanów - znakomite; określenia, jakbyś wprost z ust mi wyjął: gdy p. Dobrowolska przyjechała z powrotem z N[ew] Yorku, powołując się na \{opinię\} ${ }^{9}$ masy moich przyjaciół w Stanach, zaczęła mnie goracco namawiać do przeniesienia się - odpowiedziałem: „Pojadę do Stanów tylko jako bogaty turysta lub znany w Stanach autor”. Zresztą, skoro my trzej: Ty, Ludwik [Seidenman] i ja - niezależnie od siebie doszliśmy w tej sprawie do identycznego przekonania - widocznie jest ono słuszne.

Z Natalią [Aszkenazy-Drohojowska] - sama - widziałem się, rozmawiałem parę minut, zawiadomiłem o narodzinach Twej córki. Twoje argumenty okazały się tu decydujące. Oczywiście, w warunkach atmosfery, jaka panuje w tutejsz[ej] polsk[iej] kolonii - było rzeczą wykluczoną wysłuchać Twej rady, by porozumieć się z nią przez osobę trzecią - bo żadna osoba trzecia $z$ tut[ejszej] kolonii nie okazałaby się dyskretna i w 2 godziny później opowiadano by po mieście: „Aha, widzicie - ten niby nieprzejednany Parnicki chce zaofiarować nowemu rządowi swe usługi..." Więc wybrałem inną drogę: zobaczyłem przez okno Natalię, wychodzącą z hotelu - szybko przebiegłem ulicę (omal nie trafiłem pod auto) i przystapiłem do niej. Mam wrażenie, że oboje byliśmy bardzo zdenerwowani w czasie tej krótkiej i b[ardzo] powściagliwej rozmowy ${ }^{10}$.

$\left\{\right.$ Cóż to [za] plotkarska kolonia, jak łatwo rzuca oszczerstwa ${ }^{11}$ lub oszczerstw słucha - np. od jakiegoś czasu krąży pogłoska, że ja jestem na utrzymaniu brytlyjskiej] „Intelligence” 12 ... Bzdura - ale dziwne, że to w czasie zbiegło się z okresem pobytu tutaj nowego p[osels]twa. Wygarnąłem to Natalii w oczy. Nie wiem, jak ułożą się dalsze moje $z$ nią stosunki; wymagają wielkiej delikatności $z$ obu stron - ona powinna zrozumieć, że szkoda zachodów i czasu na przekonywanie mnie, bym przeszedł na ich stronę...

Z czego żyję? Czasem - rzadko - posyła mi co nieco Kister - z a c i ą ga m te $\dot{z}$ (na poczet powieści z historii Stanów - która a nuż rzeczywiście mi dużo da - na poczet honorariów $z$ nowego wydania Aecjusza) długi. Kredyt w kolonii mam raczej, jak dotąd, dobry - bom po otrzymaniu odprawy więcej niż połowę zużył na spłacanie wszystkich dawnych długów... Oczywiście, długo tak trwać nie może - ale nową powieść skończę za 2-3 miesiące ${ }^{13}$; a w międzyczasie chyba Kister coś więcej mi przyśle tytułem honorariów za Aecjusza.

\{Strasznie bym się cieszył, gdyby P. Marta napisała recenzję ze Sr[ebrnych] Orłów. Egzemplarz weź od Ludwika [Seidenmana] - zażądał ode mnie przysłania, właśnie w celach propagandy tej książki. Posłałem mu własny egzemplarz (oba tomy). ${ }^{14}$

\{Całuję ręce obydwu pań z rodziny Erdmanów. Ciebie ściskam serdecznie

Teodor ${ }^{15}$

Dwie pożółkłe karty papieru średniej grubości, o wymiarach $21 \times 27,5 \mathrm{~cm}$, zapisane obustronnie ciemnogranatowym atramentem; pismo równe, dość gęste. Dopisek pionowy na marginesie lewym karty 1 recto (5 linijek). Niewielki dopisek pochyły u góry karty 2 verso na lewym marginesie, zaczynający się od słów „Cóż to [za] plotkarska”, rozwinięty następnie płynnie w kolejny akapit. Krótki dopisek „do góry nogami” $\mathrm{z}$ podpisem w lewym górnym rogu karty 1 recto. $\mathrm{W}$ prawym górnym rogu karty 1 recto dopisek ołówkiem dokonany przez Erdmana: „Odpowiedziałem 5 II 46”.

1 Córka Marty i Jana Erdmanów, Anna, urodziła się 28 XII 1945. Marta na początku 1946 r. pisała do rodziców, Zofii i Melchiora Wańkowiczów: 
„Nazywa się Anna-Krystyna. Ma dwadzieścia dwa cale długości i waży, a raczej ważyła przy urodzeniu, siedem funtów i czternaście uncji [...]. Ma pyzatą buźkę do nikogo niepodobną, nie widzące jeszcze mętnoniebieskie oczka i bardzo długie włoski, ku naszemu zdumieniu - czarne. [...]

Pojawiła się na świecie $z$ minimum kłopotu. Właściwie to się trochę tego wszystkiego bałam, bo siedzimy tu zakutani na tej farmie, cztery mile od miasta, pięć od szpitala, bez samochodu, bez telefonu, a wprawy w rodzeniu, jak dotąd, nie miałam, i nie bardzo wiedziałam, czy zdążymy" (cyt. za: Wań k owicz, op. cit., s. 404).

2 Anna Erdman w 1970 r. przyjechała do Polski, studiowała medycynę; po śmierci dziadka, Melchiora Wańkowicza, odziedziczyła po nim mieszkanie przy ul. Puławskiej w Warszawie, w którym razem z mężem Tadeuszem Walendowskim stworzyła znany salon kultury niezależnej; zmarła w 2004 roku.

3 Według tradycji attyckiej, utrwalonej przez Sofoklesa, Antygona towarzyszyła swojemu oślepionemu ojcu, królowi Teb Edypowi, gdy skazany na wygnanie błąkał się po różnych krajach.

4 Kordelia była najmłodszą z trzech córek Leara w dramacie W. Szekspira Król Lear. Swoją miłość do ojca wyraziła, inaczej niż jej siostry, w bardzo skromny i prosty sposób („Kochać i milczeć” $\langle\mathrm{I}, 1,62\rangle)$; skazana na banicję, wraca, aby stanąc w obronie ojca, którego starsze córki próbują pozbawić władzy.

5 Najstarsza córka Sir Thomasa M o r e' a (1478-1535), M a r g a r e t (1505-1544), otrzymała bardzo dobre wykształcenie humanistyczne; była pisarką i tłumaczką, prawdopodobnie jedną z najlepiej wykształconych kobiet w XVI-wiecznej Anglii; podczas uwięzienia ojca w Tower często go odwiedzała, gdy zaś ścięto go i wystawiono jego głowę na widok publiczny na London Bridge, wraz z mężem Williamem Rope’em przekupiła strażnika, który miał wyrzucić głowę More’a do Tamizy; do śmierci przechowywała ją w zalewie z ziół; ostatecznie spoczęła ona w grobie męża Margaret, Williama. Margaret Rope przetłumaczyła na język angielski m.in. traktat Erazma z Rotterd a mu Precatio Dominica (A Devout Treatise upon the Paternoster).

6 Susan Augusta Feni more Co oper (1813-1894) - córka Jamesa Feni more'a C oopera (1789-1851), była pisarką, a w późniejszych latach życia swojego ojca jego sekretarką i asystentką. Planowała napisanie jego biografii, jednak na jego życzenie zrezygnowała $\mathrm{z}$ realizacji tego zamierzenia.

7 Petroniusz przed samobójstwem w liście pożegnalnym do Winicjusza, przebywającego z Ligią na Sycylii, napisał:

„Prawda mieszka gdzieś tak wysoko, że sami bogowie nie moga jej dojrzeć ze szczytu Olimpu. Tobie, carissime, wydaje się, że wasz Olimp wyższy jeszcze, i stojąc na nim wołasz na mnie „Wejdź, a zobaczysz takie widoki, jakich nie widziałeś dotychczas!" Być może. Ale ja ci odpowiadam: „Przyjacielu, nóg nie mam!« [...]

Nie! szczęśliwy małżonku królewny-jutrzenki! Wasza nauka nie dla mnie” (H. Si e n ki e wi c z, Quo vadis. Wyd. 15. Warszawa 1963, s. 607-608).

8 Na przełomie 1945 i 1946 r. Parnicki planował napisanie powieści Powrót Światowida. Nawiązując m.in. do doświadczeń i obserwacji z okresu kujbyszewskiego, zamierzał w niej przedstawić mechanizmy polityczne, które zadecydowały o tym, że Polska wyszła $z$ wojny jako państwo komunistyczne. W liście do Seidenmana z 29 I 1946, odmawiając podejmowania w artykułach tematów współczesnych, stwierdzał: „Co innego w twórczości: tam piszę, co chcę, najbardziej nieortodoksyjnie, i nic sobie nie robię ni z polityków, ni z opinii kołtuńskiej - zobaczysz, co to za kawały będa w Powrocie Światowida!" Seidenman odradzał Parnickiemu napisanie tej powieści (podobnie jak odrzucał jego pomysły, aby powieść z dziejów Nowego Orleanu opatrzyć prologiem i epilogiem, w których zostałyby podjęte wątki wojenne i powojenne). Uzupełnienie nad linia tekstu.

10 O spotkaniu Parnickiego z Natalią Aszkenazy-Drohojowską pisze w swoich wspomnieniach J. D r oh oj o w s ki (op. cit., s. 279): „Wartościowym człowiekiem, marnującym się może w tych warunkach [kolonii emigracji polskiej] był Teodor Parnicki, autor Srebrnych orłów i Aecjusza. Kłaniał się na ulicy, rozmawiał z moją żona, ale ze mną nie chciał się spotkać, bo to byłoby uznaniem komunistycznego rządu warszawskiego" .

11 Początek zdania umieszczony na lewym marginesie $z$ odnośnikiem do wcześniejszej wypowiedzi ujętej w cudzysłów: „Aha, widzicie - ten niby nieprzejednany Parnicki chce zaofiarować nowemu rządowi swe usługi...”, dalszy ciąg, zaczynający się od słów „lub oszczerstw słucha”, wpisany jest w tekście głównym. 
Secret Intelligence Service, brytyjska służba specjalna powołana w 1909 r. do prowadzenia wywiadu zagranicznego.

13 Ten projekt literacki nie doczekał się urzeczywistnienia, podobnie jak kilka następnych. Dopiero w 1953 r. Parnicki ukończy część pierwszą powieści Słowo i ciało. W roku 1954 napisze Koniec „Zgody Narodów”. W zachowanych fragmentach dziennika z 1953 r. można znaleźć również potwierdzenie, że autor w tym czasie pracował nad „powieścią bizantyjską”, która ostateczny swój kształt uzyskała jednak znacznie później, bo w 1961 r., jako część druga trylogii Twarz księżyca (zob. „In Terms of Theological Struggle”. Meksykańskie zapiski Teodora Parnickiego. Odnalazł, oprac. i do druku podał T. Marki ew ka. „Pamiętnik Literacki” 2007, z. 4, s. 167-172).

15 Dopisek „do góry nogami” w lewym, górnym rogu k. lr.

México D.F. - 11/II [19]46

Mój Kochany,

Listy nasze znów się rozminęły, głównie $z$ powodu mej niecierpliwości, a raczej silnie dającego mi się we znaki uczucia samotności i potrzeby wymiany myśli z kimś naprawdę przyjaznym. Jeśli chodzi o sprawy, które Ty poruszasz w swym ostatnim liście, to:

1) Natalia [Aszkenazy-Drohojowska] już nie mieszka w hotelu naprzeciwkoㄹ, więc nie widuje jej wcale.

2) W ogóle nie wiedziałem, że Kisterowie mają już tak dorosłą córkę ${ }^{2}$, która sama $\mathrm{z}$ kolei może mieć córkę.

3) Moje życie osobiste w Meksyku - jeżeli i istnieje - jest czymś niesłychanie odległym od tego, czego bym pragnął i psychicznie wprost potrzebował... starzeję się chyba - tzw. przygody mnie nie bawią - a tęsknię za jawnym, trwałym związkiem z kobietą, która, poza swą kobiecością, mogła[by] być Egerią ${ }^{3}$ mojej twórczości... Taki zaś związek w moich okolicznościach jest właściwie niemożliwy... Co więcej, jedyna kobieta, która mnie w Meksyku naprawdę bardzo fascynowała, odgrywała raczej rolę niszczycielską w stosunku do mojej psychiki i twórczości: robiła wszystko, żeby zniszczyć we mnie do reszty wiarę w siebie i w swój talent, i w sens mojej pracy pisarskiej... ${ }^{4}$

4) Jedynym skutecznym sposobem dopomożenia mojej żonie jest zdobycie przez moją powieść $z$ historii St[anów] Zjedn[oczonych] pieniędzy i rozgłosu. To by - szczególnie to drugie - umożliwiło chyba wywieranie nacisku pewnych kół opinii na rzecz umożliwienia mojej żonie opuszczenia Polski i przedostania się na ten kontynent. Innych sposobów ni e widzę - ni e mam. Więc jeszcze argument na to, bym się cały skupił nad tą powieścią. Niestety, atmosfery sprzyjającej za mało - grubo za mało. Inicjator całej sprawy - Ludwik [Seidenman] - milczy tak uparcie, że chyba u myśln i e. Perspektywy na minimum dochodów, umożliwiających przeżycie okresu czasu do chwili wyjścia książki - też dziwnie nikłe... Ni Kister, ni Ludwik [Seidenman] nie raczą dać mi znać, co się dzieje z zapowiedzianym na miniony grudzień nowym wydaniem Aecjusza i honorariami za nie... Ale ja się nie poddam i z drogi swej nie zejdę - jeżeli zaś $z$ niej zejdę, to już jako mechanizm psychiczno-umysłowy rozbity całkowicie - i niech później ten czy ów mecenas literatury polskiej nie deklamuje, że takie pokładał we mnie nadzieje, że tak był dla 
mnie życzliwy etc. etc.... Ja będę tylko pisać powieści: albo to nic nie jest warte, to mogę nie żyć - nie muszę żyć; albo jeśli jest warte coś dla kultury polskiej, to niechże społeczeństwo polskie troszczy się o twórczość i o autora...

Przedwczoraj byłem na obiedzie, w którym też wziął udział przybyły tu ze Stanów Rozmarek ${ }^{5}$ : inicjator obiadu po to nas zetknął, by stworzyć atmosferę, na którą (on - inicjator) liczył, że może spowoduje pomoc Polonii Amer[ykańskiej] dla mnie... Owszem: dostałem 2 propozycje - wykładać o literaturze polskiej w którymś z polskojęzyczn[ych] kolegiów Polonii w Stanach; 2) korespondencje o Meksyku do jakiegoś pisma Kongresu (czy Rady) Polonii ${ }^{6}$. Odrzuciłem o bi e propozycje.

$I-m o^{7}$, wyjazd mój z Meksyku przed (jeśli nie napisaniem, to przynajmniej) definitywnym zgromadzeniem materiałów do powieści o Cortésie - byłby kapitulacją, a ja nie chcę kapitulować.

II. Uważam się za kiepskiego dziennikarza i nie chcę nazwiska swego obciążać bzdurami, jakie bym mógł pisać jako korespondent.

III. - Orientuję się (po rozmowie z Rozmarkiem jeszcze lepiej niż dawniej), czym jest Polonia - mój typ umysłowy nie dla nich - moje ujęcie spraw kultury nie będzie im się podobało, a ja na kompromis nie pójdę.

IV. Mam pisać tylko powieści - może przyjdzie chwila, że właśnie Polonia będzie się szczycić tymi powieściami - może... ale teraz przywódcom jej nie przychodzi do głowy - przywódcom organizacji o blisko 40-tomilionowym majątku - zapytać mnie: - Panie, a może my byśmy mogli Panu pomóc w Pańskiej pracy, jako powieściopisarza? Czy nie \{ułatwiłoby Panu życia i pracy $\langle\text { przez rok - powiedzmy }\rangle^{8}$ sto dolarów miesięcznie od nas? Ale takich pytań mnie nie stawiają: widocznie Parnicki-powieściopisarz Polonii nie interesuje. Fakt, z którego wyciaganie wniosków pozostawiam w pełni samemu sobie. $\}^{9}$

\{Prosiłbym Cię, żebyś poinformował Kistera i Ludwika o propozycjach Polonii dla mnie i o moim odrzuceniu tych propozycyj. ${ }^{10}$

\{Już wzięcie się do powieści z dziejów ameryk[ańskich] to kompromis (dałem się Ludwikowi skusić perspektywą rozgłosu i pieniędzy) - może drogo, bardzo drogo za ten kompromis zapłace - bo kompromitacją, klapa.... $\}^{11}$

\{Ręce Pani Marcie całuję - ściskam Ciebie - życzenia zdrowia dla dziecka.

Teodor $^{12}$

Dwie pożółkłe karty papieru średniej grubości, o wymiarach $21 \times 27,5 \mathrm{~cm}$, zapisane obustronnie ciemnogranatowym atramentem o szarym odcieniu; pismo równe. Dopiski pionowe na marginesie lewym karty 1 recto (5 linijek), karty 2 recto (4 linijki) i verso (6 linijek). W lewym górnym rogu karty 1 recto ukośny dopisek „do góry nogami” z podpisem nadawcy.

1 Jak wynika z listu 14, Parnicki pomylił się: Natalia Aszkenazy-Drohojowska nie wyprowadziła się $\mathrm{z}$ hotelu.

2 Hanna i Marian Kisterowie mieli dwie córki: Ryszardę (ur. 1923) i Elżbietę (ur. 1932). Ryszarda wyszła za Cesarego Lombrosa, $\mathrm{z}$ którym miała trójkę dzieci: dwie córki i syna.

3 Egeria - w mitologii rzymskiej nimfa obdarzona umiejętnością wieszczenia; żona legendarnego króla Rzymu Numy Pompiliusza, udzielała mu rad w sprawach państwowych i religijnych. Jej imię służy za eponim kobiety-doradcy.

4 Nie udało się ustalić tożsamości osoby, o której Parnicki pisze.

5 Karol Rozmarek (1897-1973) - adwokat, działacz polonijny, wydawca; w latach 1939-1967 prezes Związku Narodowego Polskiego w Stanach Zjednoczonych, największej polonijnej organizacji ubezpieczeniowej; w latach 1944-1968 prezes Kongresu Polonii Amerykańskiej; zabiegał 
o większy udział Polaków w życiu politycznym USA; w latach 1949-1952 członek amerykańskiego Komitetu do Zbadania Zbrodni Katyńskiej; prezes spółki Alliance Printers and Publishers, wydającej polskie ksiażki i „Dziennik Związkowy”.

6 Najprawdopodobniej chodzi o „Dziennik Związkowy”, organ Związku Narodowego Polskiego, wychodzacy od 1908 r. w Chicago.

7 Tj. Primo. Analogicznie kolejne punkty należy odczytywać w wersji łacińskiej: Secundo, Tertio, Quarto.

Uzupełnienie nad linią główną dopisku marginesowego.

Dopisek wzdłuż lewego marginesu k. 2v.

Dopisek wzdłuż lewego marginesu k. 2r. Bez odnośników do tekstu głównego. Ostatnie zdanie tekstu głównego k. 2r brzmi: „Owszem: dostałem 2 propozycje - wykładów [...]”.

Dopisek wzdłuż lewego marginesu k. 1 r.

12 Dopisek „do góry nogami” w lewym górnym rogu k. 1r.

\section{4}

16/IV [1946], México D. F.

Droga Pani Marto, Drogi Janku,

Dawnom już nie miał od Was listu, ale ani się o to nie urażam, ani nawet się dziwię: córka to najlepsze wytłumaczenie, czemu nie ma się możliwości ani czasu do pisania listów. Zasyłam Wam obojgu najserdeczniejsze życzenia świąteczne. I mimo wszystko - proszę o list, gdy któreś $z$ was będzie miało wolną chwilę.

U mnie mało nowego. Chyba to, że mniej piję, a więcej palę. Nie czuję się też zanadto dobrze fizycznie: mieszkać blisko 2 lata na wysokości 2300 metrów $^{1}$ to się jednak daje we znaki. Poza tym? Samotność. To najważniejsze i z biegiem lat coraz trudniejsze (bardziej psychicznie niż z innych, zw[łaszcza] intymnych względów) do zniesienia. A człowiek się starzeje: białych włosów na skroniach coraz więcej... estetycznie (bo to w owej sprawie problem też istotny) osładza mi samotność obrazek główki kobiecej z XVI-XVII wieku (szkoła flamandzka) ${ }^{2}$ - urocze, typowo mieszczańskie kobieciątko, dobrze odżywione, ale nie za pulchne... Raz mi się wydaje, że ona kpi sobie ze mnie - kiedy indziej, że przygląda się pytająco. A że dzieło to sztuki malarskiej wcale niezłe, ba, może - wybitne - owo pytanie wydaje mi się wciąż odnosić do mnie, jako do artysty: gdy piszę, raz po raz spoglądam na Flamandkę: w oczach jej czytam: „on - ten, co mnie malował - potrafił stworzyć rzecz wielką. A ty? Zobaczymy, co ty potrafisz”.

Pracuję nad powieścią Konkubina ${ }^{3}$ i cieszę $\left\{\right.$ się ${ }^{4}$ (ale chwilami mam i lęk), że pierwszą czytelniczką całości będzie Pani Marta. Skończę całość pewnie w połowie maja. Wie Pani, Pani Marto, zabawna rzecz, że ja - liberał, antytotalista, niemal antypaństwowiec w zasadzie - ja, nie lubiący klasy urzędniczej i nic, ale to nic w swym typie psychicznym ni w sposobie bycia nie mający ni $z$ urzędnika, ni $z$ dyplomaty - z wszystkich licznych postaci w Konkubinie największą osobiście sympatię żywię do Sykoriusza Probusa. Tworzę go właściwie $z$ niczego, bardziej niż Hieroklesa ${ }^{5}$, niż Ablawiusza6: historia bowiem nic o nim nie wie nad to, że $z$ polecenia Dioklecjana spotkał się na moście nad rzeczką Asprudas z Królem Królów Persji - by zawrzeć umowę pokojową...

Natalię [Aszkenazy-Drohojowska] - Janku - spotykam czasem na ulicy (wciąż mieszka w hotelu naprzeciw mnie) - witamy się uprzejmie, ba, przyjaźnie - zamienimy z sobą parę słów, ale nic „drażliwego” - i to wszystko... Zabawne, jak wszyst- 
ko jest względne: b[yły] poseł Merdinger ma mi bardzo za złe nawet tego rodzaju kontakt $z$ Natalia - natomiast Tadeusz Romer robił mi w liście $z$ Londynu wyrzuty, że ją bojkotuję na gruncie pozaurzędowym - dodał nawet dość, jak na niego, opryskliwie, że to nie nada bynajmniej mojej postawie wiele bohaterstwa...

Męczy mnie moc problemów, choćby problem: pisarz-emigrant... Chwilami wydaje mi się, że powinienem jechać do Polski - ale po głębszym rozważeniu i problemu, i siebie samego dochodzę do wniosku, że taka myśl to nonsens... Oczywiście nie łudzę się też, abym na tym (naszym - obecnie) kontynencie wrósł korzeniami - nigdzie nie tkwię korzeniami - myślę, żem typowy okaz człowieka epoki przejściowej i pielgrzyma, „co się w drodze trudzi przy błyskach gromu” 7 .. Dokąd ta droga zaprowadzi? „Quien sabe”, jak to się mówi po hiszpańsku... Któż to wie? Ja sam - na pewno nie wiem...

Żona moja pracuje, jako korektorka nocna, w „Dzienniku Polskim”9 w Krakowie. Pisuje do mnie, ale listy idą bardzo wolno. Zaczynam tracić nadzieję, czy kiedyś się z nią złączymy, a trzeba się śpieszyć - starzejemy się oboje, a rozstaliśmy się jako ludzie prawie młodzi. A przecież - wydaje mi się, okres między trzydziestką a czterdziestką najważniejszy jest dla ukształtowania się definitywn[ego] stosunku [między dwojgiem ludzi. ${ }^{10}$

\{Pani Marcie ręce całuje - Janka ściskam serdecznie. Jak się ma mała? Oddany

Teodor $^{11}$

Dwie pożółkłe karty bardzo cienkiego papieru bibułowego, o wymiarach $21 \times 28 \mathrm{~cm}$, zapisane obustronnie ciemnogranatowym atramentem; pismo równe, dość gęste. Dopisek pionowy na lewym marginesie karty 2 verso.

1 Meksyk, położony na wysokości 2250 m n.p.m., jest jednym z najwyżej zbudowanych ośrodków miejskich na kuli ziemskiej.

2 Czarno-biała reprodukcja $(16 \times 20 \mathrm{~cm})$ fragmentu obrazu olejnego Portret młodych małżonków Jacoba Jordaensa z 1620 r. $(93 \times 125$ cm), znajdującego się w zbiorach Museum Fine Art w Bostonie. Na odwrocie umieszczona jest wyklejka $z$ powtórzonym kilka razy stemplem $z$ napisem: „AL MARCO ARTISTICO. FABRICA DE MARCOS MODULAS. ARTICULO 123, No. 24-I, Tel. 13-03-06; MEXICO D.F. ESPECIALIDAD EN MARCOS A LA MEDIDA".

3 Chodzi o wzmiankowaną w liście 16 powieść o Konstantynie i jego konkubinie, Minerwinie. Praca nad nią bezpośrednio poprzedzała rozpoczęcie pisania części pierwszej Słowa i ciała, doprowadzonej do końca w 1953 roku. Po latach P a rn i c ki (Historia w literature przekuwana, s. 186) wspominał: „Słowo $i$ ciało jest powieścią z dziejów cesarstwa rzymskiego, a właściwie głównie tam chodzi o problem chrześcijaństwa w cesarstwie rzymskim; przeszedłem do tego projektu pisarskiego od innego zresztą, ale na temat podobny: miała to być pierwotnie powieść o pierwszym chrześcijańskim cesarzu rzymskim, mianowicie o Konstantynie Wielkim. Przez trzy lata (od 1945 do 1948) przygotowywałem się do pisania powieści o Konstantynie Wielkim. I w 1948 przypadkowo odkryłem coś, co kazało mi zmienić temat”.

4 Dopisek nad główną linią tekstu.

5 Hi erokles - prokonsul Bitynii (we wschodniej Azji Mniejszej) za panowania Dioklecjana i Konstantyna I Wielkiego.

$6 \quad$ Najprawdopodobniej chodzi o A b la wi u s z a, wysokiego urzędnika w Myrze w Licji (w południowo-zachodniej Azji Mniejszej) z czasów Konstantyna I Wielkiego.

7 Właśc.: „przy blaskach gromu” - cytat z hymnu Smutno mi, Boże! J. Sło w a c k i e g o (w. 27-28).

8 „Quien sabe?” (hiszp.) - „Któż to wie?”

9 „Dziennik Polski”, pismo codzienne ukazujące się w Krakowie od 1945 do 1991 r. nakładem Spółki Wydawniczej „Czytelnik”. 
10 Uzupełnienie na lewym marginesie k. 2v.

11 Dopisek wzdłuż lewego marginesu k. 2v.

México D. F. - 16/V [19]46

Mój Drogi,

Nie odpowiedziałeś mi na ostatni list sprzed paru tygodni, ani w ogóle nie piszesz do mnie od stycznia ${ }^{1}$. W ogóle coraz mniej ludzi do mnie pisze - coraz mniej, widać, jest takich, których choć cokolwiek obchodzę. Od żony z Polski też już bardzo dawno nie mam wiadomości. Ba, Ludwik [Seidenman] przestał do mnie pisać, choć go wciąż zasypuję listami. Miałem natomiast list (2-gi z kolei) od prałata Meysztowicza z Rzymu i pewne ustępy tego listu, polemizujące ze mną, odbierają mi nawet powoli wiarę, by dzięki Kośc[iołowi] katol[ickiemu] świat mógł mieć przed sobą perspektywę władania dobroci i wolności... ${ }^{2}$

Wszystko to razem zmniejsza zarówno ochotę do życia, jak i wiarę w celowość własnej pracy pisarskiej... A nawet w alkoholu już trudno mi szukać przytępienia zadręczającej się wiecznie myśli i wyobraźni, jako że powoli poczyna „nawalać” mi wątroba... Raz kiedyś po upiciu się straciłem zupełnie przytomność: pierwszy raz w życiu... Ba, dotknąłem, zdaje się, nawet Wierzyńskiego ${ }^{3}$, któremu \{o jego Krzyżach i mieczach ${ }^{4}$ napisałem, że trzeba się raz zdecydować na wybór: Krzyż czy Miecz? Łączenie tych $\}^{5}$ rzeczy i idealizowanie tego łączenia pojęciem „krucjaty” to jedno z największych zakłamań w dziejach ludzkości - istny triumf ducha rzymskiego cezaryzmu, Starego Testamentu, germańskiej Walhalli ${ }^{6}$, ba, islamu wojującego nad Ukrzyżowanym, co uczył „Miłujcie nieprzyjacioły wasze”.

Zapytaj przy okazji Ludwika, czemu do mnie nie pisze.

Jak się ma Twoja córeczka? Pisz do mnie.

Pani Marcie ręce całuję, Ciebie ściskam serdecznie

Teodor

Cienka karta bibułowa, o wymiarach $21 \times 28 \mathrm{~cm}$, zapisana jednostronnie granatowym atramentem; pismo średniej wielkości, lekko pochylone. Dopisek pionowy na lewym marginesie karty 1 recto $(2$ linijki). Do karty przypięta zszywaczem bibułowa karteczka $z$ tego samego materiału $(21 \times$ ok. $10 \mathrm{~cm})$, nierówno oberwana u dołu, zapisana jednostronnie. Na karteczce tekst zaczyna się od słów „rzeczy i idealizowanie tego...”

$1 \quad$ Z adnotacji Erdmana w liście Parnickiego z 5 I 1946 (list 12) wynika, że odpowiedział on na niego 5 II 1946.

2 Wychowany w laickiej atmosferze swojego domu rodzinnego (w Berlinie, Moskwie i Ufie), Parnicki poznał bliżej katolicyzm w chińskim Harbinie, gdzie uczęszczał do polskiego gimnazjum w latach 1920-1927. Po przyjeździe na studia do Lwowa w 1928 r. początkowo bliskie mu były idee prawicowe i nacjonalistyczne oraz tradycjonalistycznie rozumiany katolicyzm. $Z$ czasem jego postawa ewoluowała w stronę pogłębionego rozumienia katolicyzmu jako religii uniwersalistycznej, a tym samym antynacjonalistycznej. To doprowadziło Parnickiego do idei katolickiego humanizmu (chrześcijańskiego personalizmu), który, w jego przekonaniu, był jedyną realną alternatywą dla ideologii politycznych Europy lat trzydziestych. W liście do Symonolewicza pisał 19 X 1933: „Zanosi się na wojnę, Kochany Panie [...]. Ale bez względu na to, czy będzie wojna, czy nie - zbliża się czas strasznej rozgrywki między - że użyję oklepanych terminów - lewicą a prawicą - będą 
to czasy straszne, będzie to straszliwe pohańbienie godności człowieczej przez instynkt stada i w tym to czasie, jak wierze - ostatnim schronem dla godności ludzkiej, dla miłości człowieka - bez względu na to, czy będzie chciał, czy nie - skazany na to przez słodką naukę miłości bliźniego, której głosiciela za swego uważa założyciela - stać się będzie musiał Kościół katolicki: dlatego właśnie chcę być "pisarzem katolickim". Już Centrum niemieckie budziło we mnie dla siebie dużo sympatii: wzruszało mię opowiadanie o bladym młodzieńcu zbierającym do puszki na partię centrową w czasie wyborów, wołając: Für Wahrheit, Freiheit und Demokratie gegen Rassen und Klassen Kampf... [tj. "dla prawdy, wolności i demokracji, przeciw walce rasowej i klasowej"]. Takie hasło przyjmuję bez zastrzeżeń!..." Kryzys wiary w tak rozumianą misję Kościoła katolickiego zaczął się u Parnickiego po wojnie, ostateczne zaś odejście od katolicyzmu miało związek z odrzuceniem przez niego dogmatu o cielesnym wniebowzięciu Najświętszej Maryi Panny, ogłoszonego przez Piusa XII w r. 1950, oraz z rozwodem i zawarciem powtórnego małżeństwa, które, zgodnie z nauczaniem Kościoła, automatycznie wykluczało go ze wspólnoty katolickiej. Analizę swego stosunku do katolicyzmu podjął pisarz pod koniec życia w autotematycznej Opowieści o trzech Metysach (1994).

Kazimierz Wierzyńs ki (1894-1969) - poeta, eseista, prozaik, członek grupy Skamander; we wrześniu 1939 opuścił Polskę i przez Rumunię, Jugosławię, Włochy dotarł do Paryża; po inwazji Niemiec na Francję, w maju 1940, wyjechał na południe Francji, a następnie przez Hiszpanię przedostał się do Portugalii, skąd 13 XI odpłynął do Brazylii; 28 XI 1940 przybył do Rio de Janeiro, a 2 VI 1941 przeniósł się do Nowego Jorku; w latach 1941-1943 redagował "Tygodniowy Przegląd Literacki Koła Pisarzy z Polski”, w latach 1943-1947 „Tygodnik Polski”, współpracował też z londyńskimi „Wiadomościami”.

$4 \quad$ K. Wi e r zy ń s ki, Krzyże i miecze. Londyn 1946. Wiersz rozpoczyna się od strofy: „Krzyże i miecze - los wybrany / I przewleczone nasze lata / i nasza krew i nasze rany, / Polski cyrograf zapisany / Na wszystkiej ziemi tego świata” (cyt. za: K. Wierzyński, Poezja i proza. 1: Poezja. Wybór i posł. M. S prusińs ki. Kraków 1981, s. 354).

5 Dopisek wzdłuż lewego marginesu k. 1 r.

6 Walhalla - w mitologii nordyckiej miejsce przebywania poległych w chwale wojowników, których z pola bitwy zabierały walkirie.

7 Słowa Jezusa wypowiedziane w Kazaniu na górze: „Miłujcie nieprzyjacioły wasze, dobrze czyńcie tym, którzy was mają w nienawiści, a módlcie się za prześladujących i potwarzających was" (Nowy Testament. W przekładzie polskim J. W u j k a. Wyd. nowe, przejrz. i objaśn. Kraków 1936, Mt 5, 44).

México D.F. - 19/VI [19]46

Drogi Janku,

Zbliża się dzień Twoich Imienin - zasyłam Ci najgorętsze życzenia, tak samo serdeczne, jak były te, które Ci osobiście składałem 2 lata ${ }^{1}$ temu przy winie w „Orient Palace Hotel" w Damaszku. Cieszyłbym się też, gdybyś nareszcie do mnie napisał. Wolę sobie tłumaczyć Twoje milczenie praca i troskami wokół córki. Nawiasem mówiąc, to wspaniała rzecz mieć córkę: duchy Edypa, św. Tomasza More, może i Fenimore Coopera ${ }^{2}$ mogłyby coś o tym powiedzieć... Boleśniejsze by było, gdybyś nie odpisywał świadomie, za coś gniewając się na mnie... Ale za co? Ja dostrzegam 2 tylko możliwości:

1) Żal - może nawet nie w pełni świadomy - że ja sobie wciąż ułatwiam życie... że chcę żyć, jak chcę, pisząc, co chcę, gdy inni - może w niejednym wartościowsi ode mnie - stanęli do ciężkiej walki z życiem, ba, z nurtem dziejów, pracując ponad siły nie w tym, co by im „odpowiadało”. Ale czy ja mam życie ułatwione? Mój Boże! Nie chcę rozwodzić się nad tym, jak mi też ciężko; a że z uporem maniaka trwam 
przy swym (nikomu niepotrzebnym, jak pewnie większość sądzi) powieściopisarstwie historycznym - to, widzisz, w tym, poza osobistym upodobaniem, jest pewna szersza idea: zdaje mi się, że Bieruta etc. wcale nie zmartwi, jeśli np. Erdman dobije się majątku w gospodarce rolno-hodowniczej - Seidenman w handlu ${ }^{3}$ - moi b[yli] koledzy z P[oselstwa] z Meksyku, Stebelski, major Dobrowolski ${ }^{4}-$ w aptekarstwie ${ }^{5}$; nie, jego tylko ucieszy, że tych ludzi ubyło - choćby chwilowo - w myślowej robocie Polski dobrowolnie emigranckiej... Otóż ja - ostatkiem co prawda sił psychicznych - próbuję, by n i e ubyć... Czy mi się uda? nie wiem... Powieść o Minerwinie i Konstantynie ${ }^{6}$ idzie ciężej niż cokolwiek kiedykolwiek dotąd... Zacząłem c ałki e m nową wersję, Ludwika [Seidenmana] to wścieka, ale ja mu sz ę...

2) Może masz jakiś żal, żem Ci nasłał (i przez to kłopoty może jakie Ci sprawił) Drozdowskiego ${ }^{7}$. Otóż tak nie było. Drozd[owski] nie jest najprzyjemniejszy i najtaktowniejszy w obcowaniu, ale że Wsch[odni] Małopolanin, zbliżyliśmy się nieco... Poza tym on (bogato się ożeniwszy) na niczym nie może się zatrzymać, wciąż szuka „interesów”, a że weterynarz z fachem, wspominał kiedyś o farmie w drobiu [!] w Stanach... Wówczas mówiłem $z$ nim o Tobie i wyobrażałem sobie nawet, że on włoży duży kapitał w taką rzecz, a Ciebie, jako kogoś już z doświadczeniem, weźmie na administratora lub wspólnika... Ale, jak powiadam, w Meksyku kiedyś mówiłem z nim o tym dość dorywczo. Aż w Wielką Środę przychodzi z N[ew] Yorku od Drozd[owskiego] list lotniczy: prosi podać mu telegraficznie Twój adres. Nie depeszowałem, bom nie miał pieniędzy, alem odwrotnie mu odpisał „air mail”. Teraz się dowiaduję, że on był u Ciebie na Wielkanoc...

Dawno nie mam listów od żony. Ostatni (z pocz[ątku] marca) szedł prawie 3 miesiące. Zmartwił mnie. Pisze, że pewnie porzuci Kraków (gdzie pracuje jako korektorka nocna) i przeniesie się do Wrocławia. Czy może to jaka akcja przymusowa przesiedlenia lwowian na „nasz” Zachód? A przy tym ja nie wierzę, by ten Zachód miał być długo „nasz”. Niech w Niemczech wzmocni się komunizm, a „okaże się”, że „klasa robotnicza Niemiec żąda zwrotu” ur-Deutsch ziem: Schlesien und Pommern $^{8}$, no, i Kreml powie, że to „just and reasonable"9. I znów pogonią Polaków na wschód w... wąski korytarz, co się zwie dziś Rzeczpospolitą...

Janku, chcę się $\mathrm{z}$ Tobą poradzić w jednej sprawie. Bardzo mi na Twej radzie zależy. Dostałem list od Gackiego: pisze, że $z$ Włoch na krótko przyjeżdżali do Londynu Wł. Żaba ${ }^{10}$ i Giedroyc, i że on $z$ nimi „obrobił” (wyrażenie moje, nie jego) sprawę pomocy materialnej dla mnie $z$ funduszów armii Andersa ${ }^{11}$ - i zaznacza, bym do Rzymu pisał, bo ta ki c h stypendiów dla polsk[ich] pisarzy, uczonych etc. $z$ tegoż funduszu jest więcej ${ }^{12}$. Ale ja mam skrupuły: 1) nigdym nie był admiratorem Andersa ani jego polityki (na bok biore teraz czysto wojenne wyczyny armii ani w ogóle „linii”); 2) uważam, że to by nakładało na mnie na przyszłość zobowiązania moralne, a to i pisarskie; 3) historiozoficznie ni moralnie nie akceptuję idei $\mathrm{kru}$ cja ty, którą oni reprezentuja, ba, a k c entują ${ }^{13}$; 4) najwa żniej sze (proszę, to rozważ dobrze) - znasz nastroje armii Andersa i w ogóle ich ideologię - otóż wydaje mi się nieprzyzwoitością wzięcie od nich pieniędzy bez uprzedniego oświadczenia im: „moja matka była tym a tym”. Bo może, wiedząc o tym, nie uznaliby mnie za godnego pomocy materialnej „od polskiej armii dla polskiego pisarza"14... Czy pisać im o tym? Wiesz, że to dla mnie zawsze \{bardzo bolesna operacja psychiczna... Powiesz: „a brałeś pieniądze jako urzędnik”. Tak, alem wła- 
śnie Romerowi, (cd. na odwrocie) $\}^{15}\{($ cd. z odwrotu) gdy był najbliższy Sikorskiego

- wyłożył „kawę na ławę”. I po jego decyzji czułem się w porządku!\} ${ }^{16}$

\{Pisz do mnie. Ręce Pani Marcie całuję, Ciebie ściskam serdecznie.

Teodor $^{17}$

Dwie karty bibułowe o wymiarach $21 \times 28 \mathrm{~cm}$, zapisane obustronnie granatowym atramentem. Pionowe dopiski marginesowe na karcie 1 verso (margines lewy, 3 linijki 〈dopisek z podpisem〉), na karcie 2 recto (2 linijki) oraz na karcie 2 verso (3 linijki). W lewym górnym rogu karty 1 recto dopisek Erdmana ołówkiem: „Odpow. 27 VI 46”.

$1 \quad$ Powinno być: 3 lata temu. W Damaszku Erdman obchodził imieniny w czerwcu 1943.

2 Zob. list 12, przypisy 3, 5 i 6.

3 Seidenman po zakończeniu w lipcu 1945 działalności Polskiego Centrum Informacji w Nowym Jorku próbował nawiązać kontakt $\mathrm{z}$ biznesmenami meksykańskimi z myślą o prowadzeniu z nimi handlu różnymi towarami produkowanymi w Stanach Zjednoczonych (wyrobami z plastiku, radioodbiornikami). Rozważał też możliwość otwarcia w Meksyku przedstawicielstwa szwajcarskiej fabryki maszyn dla warsztatów szewskich. Starania Seidenmana zakończyły się niepowodzeniem.

4 Stefan D obrow olski - major 17 Pułku Ułanów Wielkopolskich, oddelegowany do pracy w dyplomacji; w latach 1940-1942 zastępca attaché wojskowego w Ambasadzie RP w Waszyngtonie; w latach 1942-1945 attaché wojskowy w Poselstwie RP w Meksyku.

5 Po roku 1945 Dobrowolski razem z Henrykiem Stebelskim jako głównym udziałowcem założyli w Meksyku firmę farmaceutyczną.

6 Konstantyn I Wielki (272-337) - cesarz rzymski od 306 r.; przeszedł na chrześcijaństwo; w $313 \mathrm{r}$. wydał edykt mediolański, zapewniający swobodę wyznawania religii.

Min erwin a - do 307 r. konkubina (lub żona) Konstantyna I, matka jego pierwszego syna, Kryspusa. Parnicki nie napisał o nich powieści, choć taki zamysł powstał już w czasach przedwojennych, o czym świadczy jego korespondencja z Symonolewiczem: „Noszę się [...] poważnie z myślą napisania powieści-biografii (raczej w typie Zweiga niż Aecjusza) o Konstantynie Wielkim. [...] Rzecz mogłaby być aktualna: zagadnienie "państwo a chrześcijaństwo" znowu nabiera wagi [...]. Choć zasadnicza tendencja książki byłaby wybitnie filochrześcijańska, znalazłyby się przecież rzeczy, które w naszej, nasyconej klerykalizmem atmosferze, wywołałyby niemiłe dla mnie głosy oburzenia czy potępienia, a może epitety: mason! bezbożnik!... itd., itd., którymi tak hojnie u nas się szafuje [...]. Bo oto należy przyjąć jako rzeczy prawdziwie historyczne, że 1) św. Helena, matka Konstantyna, najprawdopodobniej nie była żoną, ale konkubiną Konstancjusza Chlorusa (m.in. tak ją nazywa słynny autor Historii kościelnej, wielbiciel Konstantyna, Euzebiusz, a sąd ten nie wywołuje sprzeciwu ani u św. Hieronima, ani u prezbitera Orozjusza), zreszta, wcale jej to nie ubliża, bo nie była początkowo chrześcijanką (to nie ona skłaniała syna ku wierze w Chrystusa, ale rzecz się miała wprost odwrotnie - aż w końcu prześcignęła syna w gorliwości i pobożności), prawo zaś rzymskie uznawało konkubinat za instytucję legalną. 2) Sprawa, czy Chrystus był homousios, czy homoiusios, która była przedmiotem takich poważnych walk religijnych przez całe 2 wieki - rozstrzygnięta na soborze w Nicei została nie bynajmniej na skutek zwycięstwa antyarian w teologicznym dowodzeniu, ale dzięki rozkazowi Konstantyna, dla którego spory dogmatyczne były nieciekawe i szkodliwe dla jedności państwa i który uznał siebie za najwyższy autorytet w tej sprawie. 3) Rawnoapostolnyj Konstantyn Wielki, przez Cerkiew prawosławną zaliczany w poczet świętych, na łożu śmierci otrzymał chrzest $z$ rąk biskupa ariańskiego (Euzebiusza z Nikomedii). Poza tym wszystkim przecież był to niewątpliwie gorący entuzjasta i protektor chrześcijaństwa, a w pewnym sensie - mimo wszystkich swych zbrodni i kierowania się racją stanu w sprawach kościelnych - typ wybitnie religijny, choć i nie mogę się zgodzić z kościelnym historykiem, ks. Lisieckim, że była to anima naturaliter christiana. Sądzę, że nie będzie to duża książka: najwyżej 230-250 stron maszynopisu, a może nawet znacznie mniej” (list z 13 VII 1936).

7 Osoba ta nie odgrywała w życiu Parnickiego żadnej roli, nie są znane istotne informacje na jej temat oprócz tych, które pojawiają się w liście.

8 „Ur-Deutsch [...]: Schlesien und Pommern” (niem.) - „rdzennie / prastarych niemieckich [...]: Śląska i Pomorza”. 
9 „Just and reasonable” (ang.) - „słuszne i sprawiedliwe”; formuła często używana w dokumentach dyplomatycznych.

10 Najprawdopodobniej winno być J a r o sław Ża ba (1915-1983) - inżynier, pracownik Politechniki Lwowskiej; w latach 1939-1940 w konspiracji we Lwowie, w latach 1940-1941 więziony w ZSSR, po umowie Sikorski-Majski żołnierz Armii Polskiej w ZSSR, Armii Polskiej na Wschodzie i 2 Korpusu, redaktor „Orła Białego”; w 1945 r. oddelegowany przez gen. Władysława Andersa do rozmów z przedstawicielami Ukraińskiej Głównej Rady Wyzwolenia w Rzymie; po wojnie w Anglii, organizator i członek władz Stowarzyszenia Polskich Kombatantów (SPK).

11 W roku 19452 Korpus pod dowództwem gen. Władysława Andersa dysponował milionem dolarów, który stanowił część pieniędzy przekazanych w czasie wojny przez prezydenta USA Franklina D. Roosevelta rządowi gen. Władysława Sikorskiego na cele walki zbrojnej w kraju.

12 W lutym 1946 Giedroyc założył Instytut Literacki w Rzymie, jeszcze jako agende wojskową, z zadaniem zbierania dorobku piśmiennictwa polskiego na emigracji. W tym czasie często wyjeżdżał z Włoch do Londynu i Paryża. W grudniu 1946 nawiązał kontakt korespondencyjny z Parnickim, przebywającym w Meksyku, nosił się bowiem z zamiarem wydania włoskiego tłumaczenia Aecjusza, ostatniego Rzymianina. $Z$ planów tych nic nie wyszło, ale korespondencja między Giedroyciem a Parnickim trwała aż do powrotu pisarza do kraju (zob. Gi i d r o y c, P a r n i c ki, op. cit., cz. 1-2). W roku 1955 w Instytucie Literackim ukazał się Koniec „Zgody Narodów”. Powieść z roku 179 przed nar. Chrystusa.

13 Zakończenie wojny przyniosło wyraźny podział w emigracyjnych elitach politycznych. Gen. Anders należał do grupy, która pojałtańskiego układu sił nie uznawała za długotrwały, licząc, że sprawę niepodległości Polski będzie można podjąć na nowo dzięki zbliżającemu się w sposób nieunikniony konfliktowi w obozie zwycięzców. Był przeciwnikiem wejścia Stanisława Mikołajczyka do powołanego w lutym 1946 w Warszawie Tymczasowego Rządu Jedności Narodowej, a także demobilizacji Polskich Sił Zbrojnych na Zachodzie.

8 VI 1946 w Londynie odbyła się uroczysta parada zwycięstwa, na którą Polskie Siły Zbrojne na Zachodzie nie otrzymały zaproszenia. Tydzień później, 15 VI, Polacy zorganizowali w Anconie święto żołnierza 2 Korpusu. Podczas uroczystości dowódcy poszczególnych oddziałów odczytali słowa ślubowania podpisane przez gen. Andersa: „Zespoleni z dążeniami całego Narodu tak w kraju, jak i na obczyźnie, ślubujemy trwać nadal w walce o wolność Polski bez względu na warunki, w których przyjdzie nam działać" (cyt. za: W. An ders, Bez ostatniego rozdziału. Wspomnienia z lat 1939-1946. Bydgoszcz 1989, s. 379).

14 Gen. Anders w swoich wspomnieniach odniósł się do zarzutu, jakoby przy formowaniu w ZSSR wojska polskiego różnie traktowano obywateli II RP ze względu na narodowość: „Po wielu żmudnych wysiłkach [7-8 VII 1942] uzyskałem więc zgodę władz ZSSR na ewakuację i wyjazd 70000 Polaków z Rosji Sowieckiej. Nie zgodziłem się na wyłączenie z tej liczby tych Ukraińców, Białorusinów i Żydów, którzy już byli w szeregach wojska. Władze NKWD robiły ogromne trudności, szczególnie Żydom, którzy chcieli wyjechać jako rodziny wojskowe. Perfidia sowiecka uwydatniła się w pełni w przeprowadzeniu tej sprawy. Żydów informowano, że władze polskie nie zgadzają się na ich wyjazd, a jednocześnie wojsko otrzymało stanowczy nakaz niedopuszczania Żydów do transportów. 3 sierpnia odbyłem naradę z przedstawicielami Żydów i wyjaśniłem im sytuację. Powiadomiłem ich, że rząd sowiecki zgodził się na wyjazd rodzin jedynie tych Żydów, którzy pełnią czynną służbę w szeregach wojska polskiego. Zresztą nastapiło to wyłącznie wskutek mojej interwencji. Na wyjazd innych obywateli narodowości żydowskiej rząd sowiecki się nie zgodził, nie czyniąc pod tym względem żadnych wyjątków. Poruszam tę sprawę, gdyż bolszewicy, a za nimi niektóre koła żydowskie, skorzystały z tej okazji, by piętnować "antysemityzm polski". Zachowałem szereg listów od rabinów, działaczy i obywateli żydowskich, dziękujących mi za uratowanie im życia przez wywiezienie $z$ Rosji Sowieckiej. Przeszło 4000 Żydów opuściło wraz z Armią Polską Związek Sowiecki” (ibidem, s. 133-134). Współczesny historyk zwraca uwagę, że wśród polityków i wojskowych występowała jednak pewna rezerwa przed przyjmowaniem mniejszości narodowych do wojska. Tłumaczy ją szczególnymi okolicznościami funkcjonowania Armii Polskiej w Związku Sowieckim: „Polskie Siły Zbrojne działały od początku na obczyźnie i w rozproszeniu. Na co dzień podlegały dowództwu operacyjnemu państw obcych. W tych specyficznych warunkach szczególnego znaczenia nabierała kwestia dyscypliny i lojalności względem przełożonych oraz państwa polskiego. W szeregi wojska przyjmowano przede wszystkim ludzi młodych, sprawnych fizycznie, o kwalifikacjach i predyspo- 
zycjach przydatnych w walce. Zwracano również uwagę na to, aby ludzie ci utożsamiali się bez zastrzeżeń i wahań z polityką rządu Rzeczpospolitej Polskiej. Chociaż ze względów politycznych nie formułowano tego wprost, było oczywiste, że dowódcy woleli mieć w swoich szeregach żołnierzy narodowości polskiej niż rekrutów spośród mniejszości narodowych, co do lojalności których mogły być mniej lub bardziej uzasadnione wątpliwości. W przypadku Żydów w grę wchodziła również obawa, że po wyjeździe ze Związku Sowieckiego - z czym liczono się od początku - opuszczą szeregi wojska polskiego. Jak wykazała niedaleka przyszłość, obawy te były uzasadnione. [...] Palestyna, uznawana przez Żydów za ich historyczną ojczyznę, stała się miejscem masowej dezercji żydowskich żołnierzy z szeregów wojska polskiego. Szacuje się, że z ogólnej liczby około 4 tys. żołnierzy narodowości żydowskiej opuściło polskie szeregi ponad 3 tys. ludzi. Wielu z nich wstąpiło do podziemnych organizacji żydowskich, których celem było utworzenie państwa żydowskiego w Palestynie. To poważnie osłabiło potencjał 2 Korpusu Polskiego i postawiło polskie dowództwo w niezręcznej sytuacji wobec Brytyjczyków” (J. W róbel, Żydowscy żotnierze gen. Andersa. Na stronie: http://obnt.pl/aktualnosci/zydowscy-zolnierze-gen-andersa (data dostępu: 3 II 2017〉).

Dopisek na marginesie k. 2r.

Dopisek na marginesie k. 2v.

Dopisek na lewym marginesie k. lv.

Abstract

"CIĄŻY NA MNIE [...] OBOWIĄZEK WIERNOŚCI" ("THE DUTY OF ALLEGIANCE [...] LIES HEAVY ON ME") TEODOR PARNICKI'S LETTERS TO JAN AND MARTA ERDMAN FROM THE YEARS 1944-1946

\author{
Edited by \\ ANDRZEJ DOBROWOLSKI Tarnów, TOMASZ MARKIEWKA University of Bielsko-Biała
}

The published material is a critical study of a collection of 16 letters which Teodor Parnicki (1908-1988) wrote between 1944 and 1946 from Mexico to Jan Erdman (1906-1986) and his wife Marta (1921-1982) to the United States of America. They give an insight into the writer's condition in the earliest years of his almost 15 year stay on the North American continent and show the problems he faced after he stopped working in the Polish Embassy in Mexico where he held the position of cultural attaché. They also represent his assessment of the political situation which took place in Poland after the World War II. First and foremost they uncover his deepest motives that influenced his decision to remain an emigrant. They are viewed as a kind of artistic independence manifesto as well as a sign of fidelity to Polish literary tradition and a writer's vocation. One can follow the writer at work in this period of his creative life, during which, developing various plots with a growing feeling of solitude, he was earnestly striving to renew the historical novel as a literary genre. The outcomes of such endeavours are the first part of Stowo i ciato (Word and Flesh) and Koniec "Zgody Narodów” (The End of the "Concord of Nations"). 